\author{
UNIVER SIDADE DE SÃOPAULO \\ FACULDADE DE FILOSOFIA, LETRAS E CIÊNCIAS HUMANAS \\ DEPARTAMENTO DE LETRAS MODERNAS \\ PROGRAMA DE PÓS-GRADUAÇÃO EM LÍNGUA ESPANHOLA E \\ LITERATURAS ESPANHOLA E HISPANOAMERICANA.
}

\title{
0 artista e sua época: Estudo comparado entre Mário de Andrade e José Carlos Mariátegui
}

\author{
Fabiana Camargo Pellegrini
}

Dissertação apresentada ao Programa de PósGraduação em Língua Espanhola e Literaturas Espanhola e Hispanoamericana do Departamento de Letras Modernas da Faculdade de Filosofia, Letras e Ciências Humanas da Universidade de São Paulo, para a obtenção do título de Mestre em Letras.

Orientador: Prof. Dr. Jorge Schwartz

São Paulo

2007 
Serviço de Biblioteca e Documentação da Faculdade de Filosofia, Letras e Ciências Humanas da

Universidade de São Paulo.

Pellegrini, Fabiana Camargo

P386 O artista e sua época : estudo comparado entre Mário de Andrade e José Carlos Mariátegui / Fabiana Camargo Pellegrini ; orientador Jorge Schwartz. -- São Paulo, 2007.

$151 \mathrm{f}$.

Dissertação (Mestrado - Programa de Pós-Graduação em Língua e Literaturas Espanhola e Hispanoamericana. Área de concentração: Língua e Literaturas Espanhola e Hispanoamericana) - Departamento de Letras Modernas da Faculdade de Filosofia, Letras e Ciências Humanas da Universidade de São Paulo.

1. Andrade, Mário de, 1893-1945. 2. Mariátegui, José Carlos, 1894-1930. 3. Literatura hispanoamericana (Crítica e interpretação; Estudo comparado). 4. Modernismo - América Latina. 5. Estética (Arte) - América Latina. 6. Intelectuais - América Latina - Século 20. I. Título.

$21^{\mathrm{a}}$. CDD 868.9

709.8 


\section{FOLHA DE APROVAÇÃO}

Fabiana Camargo Pellegrini

O artista e sua época: estudo comparado entre Mário de Andrade e José Carlos Mariátegui

Dissertação apresentada ao Programa de Pós-Graduação em Língua Espanhola e Literaturas Espanhola e Hispanoamericana do Departamento de Letras Modernas da Faculdade de Filosofia, Letras e Ciências Humanas da Universidade de São Paulo, para a obtenção do título de Mestre em Letras.

Área de Concentração: Língua e Literaturas Espanhola e Hispanoamericana

Aprovado em:

\section{Banca Examinadora}

Prof. Dr.

Instituição:

Assinatura:

Prof. Dr.

Instituição:

Assinatura:

Prof. Dr.

Instituição: Assinatura: 
Aos meus avós

João e Catarina (in memorium), com amor. 


\section{AGRADECIMENTOS}

Ao meu orientador, Prof. Dr. Jorge Schwartz, pelo acolhimento em minha mudança de Departamento dentro da Faculdade de Filosofia, Letras e Ciências Humanas da Universidade de São Paulo. Pela orientação, apoio e incentivo durante todo o processo de desenvolvimento deste trabalho;

À Profa ${ }^{\mathrm{D}}{ }^{\mathrm{a}}$ Ana Cecília Olmos, por acreditar neste projeto, pela atenciosa leitura e pelas preciosas e perspicazes observações antes e durante a banca de qualificação deste projeto de mestrado;

À Profa ${ }^{\text {Dra }}{ }^{\mathrm{a}}$ Maria Augusta Fonseca, pela cuidadosa leitura e valiosa orientação durante a banca de qualificação desta dissertação;

Aos professores do Departamento de Língua e Literatura Alemã, em especial ao Prof. Dr. Willi Bolle, pelo ensino em disciplinas que me inspiraram e orientaram profundamente em meu percurso acadêmico;

Aos professores da Faculdade de Arquitetura e Urbanismo, Prof. Dr. Luciano Migliaccio, à Profa ${ }^{a} r^{a}$ Maria Cecilia França Lourenço e à Profa ${ }^{2} r^{a}$ Maria Lucia Pupo, da Escola de Comunicação e Artes, pelos anos de formação,

À Michael Löwy, pela gentileza de disponibilizar material referente a José Carlos Mariátegui;

À CNPq pela bolsa de estudos concedida em 2007;

Aos funcionários da Secretaria de Pós-graduação do Departamento de Letras Modernas, pelo grande profissionalismo, que tanto nos auxilia em relação às normas e procedimentos acadêmicos; 
E por fim, aos funcionários e estagiários da Biblioteca Florestan Fernandes, do Instituto de Estudos Brasileiros da Universidade de São Paulo, bem como aos funcionários e estagiários da Biblioteca Latino-americana Victor Civita, do Memorial da América Latina, meu imenso agradecimento por toda ajuda e colaboração para o desenvolvimento desta pesquisa.

\section{AGRADECIMENTOS ESPECIAIS}

Ao meu pai, à minha mãe (in memorium) e às minhas tias, por todo amor, cuidado, exemplo de vida e dedicação ao longo destes anos;

Às minhas queridas irmãs, pelo carinho, auxílio e companheirismo de sempre;

Ao meu querido companheiro Armando Tibério, por todo amor, pela imensa paciência e apoio incondicional nos momentos mais difíceis deste trabalho;

Às revisões, indicações bibliográficas e às muitas conversas tecidas com as amigas Marina Ruivo e Marinê de Souza Pereira;

E também agradeço a todos aqueles que ao longo do tempo contribuíram com este processo acadêmico e me inspiraram através das longas conversas, discussões, traduções, indicações bibliográficas, apoio técnico, com a leitura e revisão de textos:

Andrea Porto Pallagi, Adriana Arantes, Alexandre Bispo, Aline Mendes de Oliveira, Antonio Carlos Araújo, Bárbara Campos, Celso Ledo Martins, Cristiane Andrea Gomes Rocha, Cristiane Arenas, Dionísio Bueno, Edgar Silva, Eduardo Contrera, Elza Silva Kataoka, Fabio Tagliapietra, Fernando Godoy, Flamarion Maués, Francine Maia, Gênese Andrade, Glaucia Silva, Isabel Franco, Ivan, Jandira Queiróz Albuquerque, Jochen Kauffman, José Carlos Fogo, Luciana Varkulja, Marcello Lagonegro, Márcio Moraes, Marco Aurélio Botelho, Mariana Gainza, 
Marina Machain, Paulo André Farah, Regina, Rubinho Porto Pallagi, Rui Veiga, Sandro Canavezzi de Abreu, Silvia Vitória, Tatiana Reghini, Tatá Figueiredo, Tomi Sato, Vitor Eduardo Schincariol. 


\section{RESUMO}

PELLEGRINI, Fabiana Camargo. O Artista e sua Época: estudo comparado entre Mário de Andrade e José Carlos Mariátegui. 2007. 141 fl. Dissertação (Mestrado) - Faculdade de Filosofia, Letras e Ciências Humanas de Universidade de São Paulo, São Paulo, 2007.

Este trabalho tem como intuito o estudo comparado entre Mário de Andrade (1893 - 1945) e José Carlos Mariátegui (1894 - 1930), através de seus textos críticos sobre arte e literatura. A proposta para o desenvolvimento deste estudo centrou-se na análise do projeto estético e ideológico destes autores para que, a partir desta prerrogativa, pudéssemos indagar sobre o papel do artista e do intelectual frente a sua época. No primeiro capítulo desta dissertação abordamos a relação entre Mário de Andrade e José Carlos Mariátegui perante o modernismo brasileiro e peruano. No segundo, tratamos da dicotomia entre a tradição e a modernidade, através de um "método moderno" de observação crítica da arte e da literatura, comum a ambos os autores. No terceiro capítulo desenvolvemos uma comparação entre os preceitos advindos das vanguardas européias junto a dois artistas latino-americanos: Candido Portinari e José Sabogal. Por fim, procuramos examinar as condições nas quais o artista e o intelectual desenvolvem suas obras e o conceito de mediação decorrente de suas atuações.

Palavras-chave: 1. Mário de Andrade (1893 - 1945); 2. José Carlos Mariátegui (1894 - 1930); 3. Modernismo América Latina; 4. Arte e literatura. 


\section{RESUMEN}

PELLEGRINI, Fabiana Camargo. El Artista y su Época: estudio comparado de Mário de Andrade y José Carlos Mariátegui. 2007. 141 f. Disertación (Maestría) - Facultad de Filosofía, Letras y Ciencias Humanas de la Universidad de São Paulo, São Paulo, 2007.

Este trabajo tiene por objetivo el estudio comparado de Mário de Andrade (1893 - 1945) y José Carlos Mariátegui (1894 - 1930), a través de sus textos críticos sobre arte y literatura. La propuesta para el desarrollo de este estudio se centró en el análisis del proyecto estético e ideológico de estos autores para poder indagar, a partir de esta prerrogativa, el papel del artista y del intelectual frente a su época. En el primer capítulo de esta disertación abordamos la relación entre Mário de Andrade y José Carlos Mariátegui frente al modernismo brasileño y peruano. En el segundo, tratamos de la dicotomía entre la tradición y la modernidad, a través de un "método moderno" de observación crítica del arte y de la literatura común a ambos autores. En el tercer capítulo desarrollamos una comparación entre los preceptos provenientes de las vanguardias europeas y dos artistas latinoamericanos: Candido Portinari y José Sabogal. Finalmente, procuramos examinar las condiciones en las que el artista y el intelectual desarrollan sus obras y el concepto de mediación que resulta de sus actuaciones.

Palabras clave: 1. Mário de Andrade (1893 - 1945); 2. José Carlos Mariátegui (1894 - 1930); 3. Modernismo América Latina; 4. Arte y literatura. 


\section{Summary}

PELLEGRINI, Fabiana Camargo. The artist and his time: Comparative study between Mário de Andrade and José Carlos Mariátegui. 2007. 141 pages. Paper (Masters degree) - Philosophy, Literature and Human Science Department of the University of Sao Paulo, Sao Paulo, 2007.

The objective of this paper is the comparative study between Mário de Andrade and José Carlos Mariátegui, through their reviews on art and literature. The proposal for developing this study is centered in the analysis of the authors' ideological and esthetic projects so that from this prerogative the investigation about the role of the artist and of the intellectual in their time is made possible. In the first chapter of this paper the relationship between Mário de Andrade and José Carlos Mariátegui before the Brazilian and Peruvian modernism is examined. In the second the dichotomy between the tradition and modernity is dealt with, through a "modern method" of critic observation of the art and literature, common to both authors. In the third chapter a comparison is developed between the rules that come from the European vanguard in two Latin American artists: Candido Portinari and José Sabogal. Finally, the conditions in which the artist and the intellectual develop their work and the concept of mediation resulting from their actuation, is examined.

Key words: 1. Mário de Andrade (1893 - 1945); 2. José Carlos Mariátegui (1894 1930); 3. Latin American Modernism; 4. Art and Literature 


\section{S U M Á R I O}

INTRODUÇÃO:

12

CAPÍTULO 1:

Entre vidas e obras: Mário de Andrade e José Carlos Mariátegui

CAPÍTULO 2:

$A$ arte entre conceitos

CAPÍTULO 3:

A arte entre a teoria e a prática: Candido Portinari e José Sabogal 70

CAPÍTULO 4:

Arte e Expressão Artística: considerações finais 133

BIBLIOGRAFIA 144 


\section{Introdução:}

Este trabalho tem como intuito desenvolver um estudo comparado entre Mário de Andrade (1893 - 1945) e José Carlos Mariátegui (1894 - 1930) no que se refere ao papel do artista e do intelectual junto à sociedade, a partir das reflexões sobre estética desenvolvidas por esses autores. Por meio desta questão poderemos verificar como ambos autores orientaram artistas e público influenciando-os quanto às características de uma obra de arte que fosse ao mesmo tempo moderna e nacional - tendo em vista seus aspectos e procedimentos tanto formais quanto ideológicos - em relação à época vigente.

Cabe salientarmos os diversos percursos que tomamos ao longo de nosso estudo, para esclarecermos ao leitor os caminhos que nos levaram à relevância desta nossa problemática. Na primeira fase deste projeto, nossa intenção era pesquisar o contato que Mário de Andrade e José Carlos Mariátegui travaram com a estética expressionista alemã, e com isso analisar a recepção desta escola pelas vanguardas artísticas latino-americanas. $O$ interesse destes dois escritores sobre o Expressionismo alemão foi impulsionado pelos contatos que tiveram com obras de arte e/ou artistas que se ligavam a este movimento. Ambos também promoveram, através de suas produções intelectuais - pautadas um em sua produção em prosa, seja de ficção ou crítica, e o outro principalmente pela prática da crítica jornalística -, uma profunda reflexão sobre esta proposta estética, bem como a divulgaram em seus países de origem. Neste caso, Brasil e Peru. Não deixaremos este assunto de lado, pois o retomaremos no decorrer de nosso projeto, no que se refere ao interesse que esses autores tiveram a respeito da prática política intrínseca ao expressionismo alemão, bem como o entendimento que desenvolveram sobre as potencialidades expressivas advindas dessa experiência artística. Porém nosso tema sofreu algumas alterações, devido a fatores que julgamos de suma importância para o seu desenvolvimento. 
Como não tivemos acesso ao acervo pessoal de Mariátegui, no que se refere a livros e cartas pessoais voltadas à abordagem deste tema ${ }^{1}$, nossa pesquisa de mestrado encaminhou-se para a análise e levantamento geral sobre sua produção crítica, que referencia seu pensamento estético-ideológico, para termos condições de num futuro projeto de trabalho analisarmos documentos mais específicos que cotejem as ricas leituras que estes autores fizeram das obras expressionistas. José Carlos Mariátegui correspondeu-se com artistas e escritores alemães, dentre os quais George Grosz e Herwarth Walden, que colaboraram com a revista Amauta, bem como possuiu exemplares da revista alemã Der Sturm em sua biblioteca pessoal. Também pelo fato de que há poucos estudos sobre o pensamento estético de Mariátegui, pois a maior parte das análises que foram feitas reflete sobre sua atuação política, o que nos fez pensar na hipótese de que seria importante neste primeiro momento partir de uma pesquisa voltada ao lado menos conhecido de sua obra. Já no que diz respeito ao expressionismo em Mário de Andrade, junto aos próprios textos escritos por este autor, em que é possível levantar a influência da estética expressionista em sua produção, há também o acervo de revistas - dentre as quais também se encontra Der Sturm - e livros, onde constam anotações marginais que promovem o diálogo travado por Andrade junto aos autores alemães. Por ora, temos o conhecimento que este rico acervo encontra-se em fase final de organização, através do excelente trabalho de pesquisa de Rosangêla Asche de Paula - sob a orientação da Profa ${ }^{2} r^{a}$ Telê Ancona Lopez - que pretende disponibilizar este conteúdo, como também as notas de pesquisa de Mário de Andrade, através de um cd-rom e no site do Instituto de Estudos Brasileiros da Universidade de São Paulo².

\footnotetext{
${ }^{1}$ Sabemos apenas que Harry Vanden organizou entre 1973 e 1974 o acervo de Mariátegui, que se encontra atualmente na Biblioteca da Universidad Nacional Mayor de San Marcos, em Lima, no Peru. Estão disponíveis na Internet (http://sisbib.unmsm.edu.pe/Exposiciones/JCMariategui/mariategui.htm) apenas alguns títulos e capas de seus livros pessoais.

2 Da importância do acervo de Mário de Andrade sobre obras do expressionismo alemão, ressaltamos as observações feitas por Rosângela Asche de Paula, por ocasião da coleta de materiais que realizou junto às bibliotecas de Berlim. Segundo a pesquisadora, há livros que acusam nestas bibliotecas a informação de "possivelmente perdido na guerra" e que se encontram em perfeito estado de conservação na biblioteca de Mário de Andrade. Alguns desses livros são: Dichtungen, de Georg Trakl, na primeira edição de 1919, Diensterweg, de Gottfried Benn, de 1918 e o Ecce homo, de Georg Grosz. ASCHE DE PAULA, Rosângela. "Quando dois acervos se
} 
Devido às questões que acabamos de apresentar, decidimos manter o estudo comparado entre Mário de Andrade e José Carlos Mariátegui, pois averiguamos que, para além de algumas características que os unem em torno de seus interesses sobre a cultura alemã, há ainda a coincidência entre as leituras de autores em comum, que realizaram, e através da qual perpassam suas reflexões sobre arte, como as obras de: Benedetto Croce, Oswald Spengler, José Ortega y Gasset, Romain Rolland, dentre outros. Em decorrência da influência intelectual pela qual percorrem suas obras, verificamos que há ainda entre estes dois escritores uma atitude crítica que se fez de grande interesse em pesquisar: a de dois intelectuais que buscaram reorganizar a cultura de seus países por meio de uma profunda reflexão sobre a prática artística em relação ao meio social no qual está inserida, visando uma forma dialética entre a produção e a recepção da obra de arte, para que com isso vislumbrassem sua função junto à sociedade.

Tanto em Mário de Andrade como em José Carlos Mariátegui podemos observar a análise sobre a realidade de seus países, Brasil e Peru, através de uma série de dicotomias como: Marxismo e Cristianismo, Nacional e Internacional, Individual e Coletivo, Aristocracia e Burguesia, Decadente e Destruidor, Revolução e Construção, características estas que estão envoltas pela relação entre a Tradição e a Modernidade, porém nem todas abordadas em nosso trabalho.

No entanto, há algumas questões que os diferenciam fundamentalmente. Uma delas é a de que não temos notícia de qualquer contato entre eles durante a época em que são atuantes; eles não se conheceram nem pessoalmente, nem pela leitura da obra de um ou de outro. Também no que se refere ao intuito de suas reflexões críticas, é importante salientarmos que durante a década de 1920, voltam-se a objetivos diferentes, pois, enquanto em Mário de Andrade predominam considerações pautadas na análise estética, José Carlos Mariátegui, por sua vez, tem sua crítica movida por propósitos estritamente ligados à prática política. Tal atitude, no entanto, da importância voltada às características formais, Instituto de Estudos Brasileiros. São Paulo: IEB; Ed. 34, n. 43, set. 2006, p. 152. 
se modifica em Mário de Andrade no decorrer de sua obra. Assim, percebemos que esses autores acabam por se encontrar quanto aos interesses que movem suas considerações estéticas, pois visam refletir sobre a função da arte como transformadora do olhar em relação à realidade social. Partindo desta constatação, torna-se imprescindível analisarmos também ambos autores quanto às suas perspectivas teóricas, no que se refere ao contexto e à finalidade vislumbrada por suas formulações críticas, bem como práticas, no que diz respeito tanto ao emprego da linguagem em suas próprias escrituras, como da observação da linguagem empregada nas obras de arte. Mário de Andrade pauta suas teorias fundamentalmente sobre a linguagem artística, para compreender sua função política e social. Já para Mariátegui não se é possível conhecer uma época, se não se conhecem suas formas artísticas. Por isso, suas reflexões sobre política e sobre a conjuntura social levam muitas vezes a citações e comparações que pairam sobre a reflexão estética.

Voltando aos objetivos inicialmente expostos neste estudo, buscamos estabelecer uma metodologia que possibilitasse o estudo comparado entre ambos autores. Primeiramente quanto à delimitação das obras a serem tratadas, as fontes consultadas e o período abordado. Em relação a Mário de Andrade, privilegiamos na obra deste autor os textos em prosa, como artigos, ensaios e prefácios. Averiguamos, neste tipo de gênero do discurso, como Andrade volta-se à reflexão e ao debate político, o que nos possibilita de maneira mais contundente traçar uma análise do emprego e do alcance da voz do artista e do intelectual junto à sociedade da época. Devido à complexidade e à imensa produção literária deste autor, selecionamos alguns de seus textos, os quais julgamos de maior relevância para nosso estudo, como Prefácio Interessantíssimo (1921), A escrava que não é Isaura (1925), O Aleijadinho (1928) e outros textos contidos em Aspectos das Artes Plásticas no Brasil (1965), O Baile das Quatro Artes (1943), O Empalhador de Passarinhos(1945), além daqueles advindos de sua colaboração com alguns jornais e revistas da época como em o Diário Nacional (1926-1932), Folha da Manhã (1943-1945), entre outros. No que diz respeito à época de sua produção, devemos levar em conta as mudanças ocorridas quanto ao enfoque 
dado aos temas e preocupações que percorrem a obra de Mário de Andrade. No período compreendido entre a década de 1920 a 1930, essa é caracterizada principalmente por escritos cujo escopo se refere mais às suas percepções sobre estética. A partir do início da década de 1930 - se assim pudermos segmentar, sem o prejuízo de caracterizar a elaboração de seu pensamento - o autor passa a questionar de modo mais sistemático a arte em relação à sua função política e social. É deste período sua reavaliação crítica sobre a importância da semana de Arte Moderna no Brasil, expressa no texto O Movimento Modernista (1942), bem como sua análise sobre as condições da arte, do artista, do mercado da arte e política cultural, expressa no texto $O$ Banquete ${ }^{3}$.

Já em relação a José Carlos Mariátegui, a maior parte da produção considerada pelo próprio autor como sendo a mais relevante - refere-se ao período entre 1923, quando do seu retorno de uma viagem à Europa, e 1930, ano de sua prematura morte. Este intervalo de tempo abrange o momento em que Mariátegui colabora com as mais importantes revistas da época em Lima, bem como quando se torna consultor intelectual e de artes, participando de júris que o influenciam a publicar, segundo Augusto Tamayo ${ }^{4}$, no Editorial Minerva. Em 1926 funda Amauta, uma revista que, de acordo com Mariátegui, pretende ser um veículo com clara definição ideológica, possuindo ensaios que debatessem economia, política, literatura, artes, educação, dentre outros temas. Neste intervalo de sete anos, Mariátegui escreveu seus textos mais substanciais e lançou dois livros, sendo eles La escena contemporanea (1925) e Siete ensayos de interpretación de la realidad peruana (1928). Após sua morte, seus filhos publicaram três outros livros organizados quase que integralmente pelo autor e iniciaram um processo de compilação dos textos editados em algumas revistas da época, sendo estas Mundial, Variedades, El Tiempo, Amauta e algumas outras revistas estrangeiras. É nesta compilação que encontramos a maior parte dos textos escritos sobre arte e cultura pelo autor.

\footnotetext{
${ }^{3}$ Esta obra, O Banquete, se refere a uma série de artigos escritos por Mário de Andrade na coluna Mundo Musical, presente no jornal Folha da Manhã, de São Paulo. É um texto não acabado, escrito entre 1944 e 1945, e postumamente publicado por Jorge Coli e Luis Carlos da Silva Dantas. Ver: ANDRADE, Mário. O banquete. São Paulo: Duas cidades, 1977.

${ }^{4}$ Conforme TAMAYO, Augusto. Literatura peruana. Lima: Peisa/Editorial Inca, 1992, p. 748.
} 
Tomamos então como base para nossas reflexões a reunião de textos publicados no livro El Artista y la Época (1959), do qual procuramos analisar principalmente os dois primeiros capítulos, El artista y la Época e Tópicos de Arte Moderno, que apresentam de um modo bastante contundente algumas das indagações de Mariátegui sobre a condição da arte e do artista na sociedade e suas idéias sobre as vanguardas artísticas européias e hispano-americanas. A partir destes textos, buscamos levantar outros ensaios distribuídos nas edições das obras completas organizadas por seus familiares, na tentativa primeira de reunir e averiguar os escritos sobre arte desenvolvidos pelo autor. Verificamos também que quase toda a obra editada, em muitos dos textos que até aqui tivemos a oportunidade de contato - seja de política, seja de educação - abordam de um modo geral tanto questões da arte quanto de cultura ${ }^{5}$. Não incluímos por ora aqueles não necessariamente escritos por Mariátegui, mas observamos que são de grande importância no conjunto de sua obra. Destes, salientamos os editados na revista Amauta, meio pelo qual se desenvolveu uma rede de debates e publicações que refletem a organização e seleção feita pelo seu editor. Da leitura destes textos, é possível estabelecer pontos de contato entre os ensaios publicados por alguns colaboradores e o projeto estético e político de Mariátegui, tendo em vista a divulgação de artistas e o espaço aberto à reflexão e ao debate tanto sobre arte como outros temas que tratam da realidade peruana.

Tendo em vista os textos selecionados, teremos como fio condutor de nosso percurso sobre o papel do artista em relação à sua época, a análise da crítica de arte produzida por esses dois escritores. Entendemos que é a partir da relação entre forma e conteúdo atribuídos a uma obra de arte que poderemos levantar características tanto dos caminhos percorridos e dos objetivos vislumbrados sobre estética de nossos autores, como das obras em si mesmas, eleitas por eles para configurarem uma idéia de arte de cunho nacional. As definições sobre forma e conteúdo, segundo Antonio Gramsci, assumem

5 Conforme dados levantados por Leila Scorin: "de acordo Albert Dessau, professor da Universidade de Rostock (ex-República Democrática Alemã), 40\% dos escritos de Mariátegui ocupam-se de literatura e estética" (cf. Luna Vegas in Vv. Aa., 1980: p.09). 
significados diferentes no decorrer da história da arte. Se, no entanto, mesmo quando se admite - tomando como referência a história da arte e/ou determinados artistas - que estas palavras expressam a mesma coisa, isto ainda não significaria, de acordo com Gramsci, a impossibilidade de se distinguir o que vem a ser forma e conteúdo em arte. A prioridade do conteúdo sobre a forma ocorre muitas vezes pelo fato de ele ser interpretado como mais democrático. Já quando se considera a arte como um processo, as modificações de conteúdo seriam necessariamente modificações de forma, sendo válido também seu contrário, pois quando se atinge uma forma satisfatória, pode-se dizer que o conteúdo também se modificou. (GRAMSCI, [1929-1935], 1978, p. 66). No entanto, ainda segundo este autor, há momentos em que para além de um significado "estético" atribuído a esses conceitos, é importante que se leve em conta um significado "histórico". Forma "histórica" significa o uso de uma determinada linguagem, o que entendemos referir-se ao estilo lingüístico empregado, que varia de acordo com o meio e para com o público ao qual o artista se dirige. Quanto ao conteúdo "histórico", trata-se de um determinado modo de pensar, de acordo com uma determinada época. Como exemplo, o autor cita o termo "romantismo" que, apesar de suas muitas definições, importa ser entendido - em sentido lato - por "uma particular relação entre os intelectuais e o povo, a nação; isto é, trata-se de um particular reflexo de democracia nas letras" (GRAMSCI [1929-1935], 1978, p. 67).

Considerando-se os conceitos levantados, perguntamo-nos o porquê da "eleição", por parte dos autores pesquisados, de algumas escolas de vanguardas artísticas e de alguns artistas como "representantes" de uma obra de arte que pudesse refletir uma identidade nacional - seja a brasileira ou a peruana.

Para tentarmos responder a algumas destas questões, propomos um plano para a dissertação de mestrado que compreende quatro capítulos. O primeiro irá esboçar uma apresentação e comparação entre a vida e a obra de Mário de Andrade e José Carlos Mariátegui em relação à época de suas produções críticas. Esse capítulo, Entre vidas e obras: Mário de Andrade e José Carlos Mariátegui objetiva apresentar a relação destes autores com o modernismo brasileiro e peruano. O segundo capítulo, A arte entre conceitos, corresponderá 
a uma comparação entre a idéia de tradição e modernidade desenvolvida por estes autores. A partir dessa dicotomia procuramos analisar como as idéias entre o local e universal, aristocracia e burguesia, a atitude individual ou coletiva do artista perante a sociedade, irão reger parte de seus pensamentos críticos. $O$ terceiro capítulo, A arte entre a teoria e a prática: Candido Portinari e José Sabogal, irá confrontar os textos críticos, dos autores estudados, em relação às vanguardas européias e sua influência na América Latina. Tomaremos como referência para nossa investigação dois artistas, Candido Portinari e José Sabogal, "eleitos" por Mário de Andrade e José Carlos Mariátegui, como representantes de uma arte nacional. O quarto e último capítulo - Considerações finais: arte e expressão artística - terá como fim avaliar o que Mário de Andrade e José Carlos Mariátegui refletiram sobre a função do artista e do intelectual em relação à sua época. 


\section{Capítulo 1: Entre vidas e obras: Mário de Andrade e José Carlos Mariátegui}

Para se pensar o projeto estético-ideológico em relação à produção crítica de Mário de Andrade e José Carlos Mariátegui, objetivamos antes compreender qual o contexto no qual estão inseridos, para que com isso possamos confrontar as relações traçadas entre suas vidas e obras. Ao nos referirmos a tal proposição, tomamos as questões apontadas por José Luiz Lafetá sobre a dialética entre o projeto estético, que entende como sendo as operações que ocorrem no nível da linguagem, e o projeto ideológico, que está diretamente ligado ao pensamento, a uma visão de mundo frente a uma determinada época (LAFETÁ, 2001, p. 20). Esta época, no caso de nossos autores, representa o momento em que vivem entre o Modernismo e o Vanguardismo latino-americano, que mesmo não ocorrendo simultaneamente no Brasil e no Peru, encontram-se nas características que visam romper com a forma tradicional empregada na arte, como também enfrentam as condições e diferenças locais que se interpõem à modernidade desses dois países. Ainda conforme este autor, há diferenças importantes a serem consideradas na análise desse tipo de projeto, como a do "poder que tem uma ideologia de se disfarçar em formas múltiplas de linguagem; revestindo-se de meios expressivos diversos dos anteriores, pode passar por novo e crítico o que permanece velho e apenas diferente" (LAFETÁ, 2001, p. 20)

O modernismo na América Latina ${ }^{6}$ tem início na primeira metade do século $\mathrm{XX}$, como proposta de ruptura em relação à linguagem tradicional e ao passado colonial, sendo um novo meio de busca expressiva e de novas formas de compreensão do homem, da vida e da arte. Em linhas gerais podemos dizer que

\footnotetext{
6 "No Brasil, correspondendo, em linhas gerais, ao Modernismo hispano-americano, podemos dividir didaticamente a segunda metade do século XIX em Parnasianismo (1868-1893) e Simbolismo (1893-1922). É a chamada geração de 1870 que inclui também o Realismo. Este período de transição entre os séculos XIX e XX ainda não foi bem delimitado e caracterizado em nossos países hispano-americanos, onde a literatura não obedece a uma ordem cronológica: há justaposição de correntes estéticas diante da sucessão européia. Por isso, as fronteiras diluem-se e a terminologia varia. O que chamamos no Brasil de Parnasianismo e Simbolismo, a HispanoAmérica chama de Modernismo. O nosso Modernismo no Brasil corresponde à Vanguarda nos demais países da América". JOZEF, Bella. História da Literatura Hispano-Americana. 3. ed. Rio de Janeiro: F. Alves, 1989, p. 113.
} 
tanto no Brasil como no Peru o modernismo resulta do processo de modernização e crescimento das cidades - principalmente em metrópoles como São Paulo e Lima -, do desenvolvimento técnico e industrial, do aumento das exportações café, açúcar, algodão, petróleo e cobre - e da ascensão da burguesia comercial e industrial. No entanto, o caráter progressista dado a este processo, principalmente tendo em vista o modelo europeu, leva-nos ao questionamento da possibilidade ou não de equiparação de um desenvolvimento econômico concomitante ao desenvolvimento cultural deste período. Conforme Néstor García Canclini, o modernismo cultural europeu não resultou apenas do desenvolvimento socioeconômico, mas de um complexo entrecruzamento social, em que "as elites se encarregaram da interseção de diferentes temporalidades históricas e trataram de elaborar com elas um projeto global" ${ }^{7}$ que vem a determinar o modernismo cultural. Tomando ainda algumas das indagações desse autor, seria importante verificarmos como as diferentes temporalidades sociais e econômicas se entrecruzam e se contradizem na América Latina e com isso averiguarmos como se desenvolveram alguns dos projetos de modernização cultural.

No Brasil, este processo culmina com o advento da Semana de Arte Moderna $^{8}$, em 1922, tomado como divisa de uma série de acontecimentos anteriores, que levaram os artistas a instaurarem um novo discurso no qual o caráter de dissolução do modelo europeu e a necessidade de configuração de uma vanguarda artística e nacional tornam-se emblemáticos através de manifestos como o da Poesia Pau Brasil (1924) e Antropófago (1928), de Oswald de Andrade.

Este ímpeto modernizador da década de 1920 será reavaliado por Mário de Andrade numa conferência pronunciada em 1942, intitulada O Movimento

\footnotetext{
7 GARCÍA CANCLINI, Néstor. "Culturas híbridas: estratégias para entrar e sair da modernidade" ; São Paulo: Editora da Universidade de São Paulo, 2006, p. 73.

8 "A transformação do mundo com o enfraquecimento gradativo dos grandes impérios, com a prática européia de novos ideais políticos, a rapidez dos transportes e mil e uma outras causas internacionais, bem como o desenvolvimento da consciência americana e brasileira, os progressos internos da técnica e da educação, impunham a criação de um espírito novo e exigiam a reverificação e mesmo a remodelação da Inteligência nacional. Isto foi o movimento modernista, de que a Semana de Arte Moderna ficou sendo o brado coletivo principal." ANDRADE, Mário. O Movimento Modernista. In: Aspectos da Literatura Brasileira. 6. ed. Editora Itatiaia, 2002. X, p. 253.
} 
Modernista. Ao verificarmos o olhar em retrospectiva do autor sobre sua atitude pessoal e estética em relação à Semana de 22, podemos notar como o homem, artista e crítico, que foi Mário de Andrade, está envolto em relações conflituosas entre suas aspirações como escritor e a consciência da prática política e social de sua época.

O homem Mário de Andrade era filho duma burguesia mediana, politicamente liberal, de formação religiosa Católica e conservadora. No início dos anos de 1920, de acordo com suas palavras, escrevia poesias tipicamente parnasianas e explorava ao mesmo tempo outras que tendiam ao simbolismo, lendo de modo desorientado alguns "futuristas de última hora" e, junto a estas diferentes perspectivas literárias, concebendo também a idéia de realizar um livro em forma de verso-livre ${ }^{9}$. Como se nota, sua formação intelectual ocorre em meio às influências de uma família tradicional paulista, que lhe causava ocasionalmente algumas dificuldades quanto aos valores morais concebíveis para a época, e os livros, que the geravam problemas quanto às necessidades vitais da subsistência diária.

(...) Já ganhava pra viver folgado, mas na fúria de saber as coisas que me tornara, o ganho fugia em livros e eu me estrepava em cambalaxos financeiros terríveis. Em família, o clima era torvo. Se Mãe e irmãos não se amolavam com as minhas "loucuras", o resto da família me retalhava sem piedade. E com certo prazer até: esse doce prazer familiar de ter num sobrinho ou num primo, um "perdido" que nos valoriza virtuosamente. Eu tinha discussões brutais, em que os desaforos mútuos não raro chegavam àquele ponto de arrebatação que...porque será que a arte o provoca! $A$ briga era braba, e se não me abatia nada, me deixava em ódio, mesmo ódio. (ANDRADE, [1942], 2002, p. 256)

É deste período o livro Paulicéia Desvairada (1920-1921), que surge como o resultado das tentativas de Mário de Andrade em romper com as formas parnasianas de sua produção poética: "o estouro chegara afinal, depois de quase ano de angústias interrogativas" ${ }^{10}$. Este livro inicia com uma introdução, Prefácio

\footnotetext{
9 Ibidem, p. 255.

10 Ibidem, p. 256.
} 
Interessantíssimo, na qual o autor desenvolve sua teoria sobre a arte e as condições intrínsecas ao fazer poético. Para Andrade, o conceito de beleza em arte difere-se do advindo da beleza natural, pelo fato de a arte ter característica transitória, expressar uma "questão de moda", enquanto a natureza é imutável. Dessa maneira a arte não deve ser a reprodução fiel da natureza - assim como entende ser a fotografia neste momento - pois apesar de seus temas partirem do mundo objetivo, a arte deve conduzir à "idealização livre, subjetiva, permitindo criar todo um ambiente de realidades ideais onde sentimentos, seres e coisas, belezas e defeitos se apresentam na sua plenitude heróica"11. Assim, o belo artístico - que não deve ser confundido com o belo horrível - é aquele que se afasta do natural, e o artista por sua vez, é o responsável pelo processo desta "deformação". Tentando então formular uma teoria que explicasse a poesia moderna e o fazer artístico, Mário de Andrade desenvolve ao longo deste prefácio a importância do Inconsciente como impulso criador. Pautando-se em teorias de diversos escritores, como por exemplo a do francês Theódule Ribot (1839-1916) ${ }^{12}$, Andrade procura justificar os caminhos que levam à criação artística a partir da inspiração, sendo essa trazida do estado de inconsciência ao estado de consciência, concretizada pela linguagem e, por meio desta, compartilhada entre o poeta e o leitor. A inspiração, que nasce do subconsciente, assim como a loucura, leva o poeta à sensação de liberdade, condição essa necessária à sublimação Lírica. Essa relação entre inspiração artística e técnica é sintetizada segundo a fórmula de Paul Dermée - "Lirismo + Arte = Poesia"13 - através da qual o autor de O Movimento Modernista formula, em um dos textos iniciais de sua produção crítica, o processo artístico que leva ao desenvolvimento da arte moderna. As concepções traçadas sobre a poesia moderna serão retomadas e corrigidas em $A$ escrava que não é Isaura (1925), quando Mário de Andrade revê a importância dada ao impulso lírico em relação às leis estéticas para a concepção da poesia.

\footnotetext{
${ }^{11}$ ANDRADE, Mário de. Paulicéia Desvairada. São Paulo: Casa Mayença, 1922, p. 18-19. (Ed. facsimilar)

12 "Ribot disse algures que inspiração é telegrama cifrado transmitido pela atividade inconsciente à atividade consciente que o traduz. Essa atividade consciente pode ser repartida entre o poeta e o leitor. Assim aquele não escorcha e esmiúça friamente o momento lírico; e bondosamente concede ao leitor a glória de colaborar nos poemas". Ibidem, p. 31.

${ }^{13}$ Ibidem, p. 15.
} 
Assim, a fórmula de Dermée é alterada para "Lirismo puro + Crítica + Palavra = Poesia", e a retomaremos mais adiante a fim de comparar as mudanças ocorridas nestas teorias a partir da análise entre a relação forma e conteúdo da obra de arte.

Se rememorarmos o início deste nosso percurso sobre o homem Mário de Andrade, e nos pautando ainda em algumas afirmações de Telê Ancona Lopez, pode-se dizer que a doutrina cristã influenciou fortemente este autor quando começava a escrever, o que o levava a relacionar muitas vezes os aspectos sociais desta doutrina à sua formação liberal. Por isso, as mudanças quanto ao caráter de suas observações sobre o plano individual e social - no que se refere à participação do artista na sociedade - irão aos poucos se transformar, conforme o desenrolar de suas reflexões, como também devido às transformações políticas que ocorrem no Brasil a partir da década de 1930.

Mário de Andrade, que segundo suas palavras "nunca soube" quem teve a idéia da Semana de Arte Moderna, não só participou desta, tornando-se participante e animador das principais revistas deste movimento (Klaxon, Estética, Terra roxa, dentre outras), como também desenvolveu uma intensa criação literária, estudou e lecionou música, foi interessado nas artes plásticas, na dança, na língua e no folclore brasileiro ${ }^{14} \mathrm{E}$ mesmo tornando-se um dos principais intelectuais de nossa vanguarda artística, reavalia este período de maneira melancólica, traçando considerações sobre o que foi sua vida e sua arte, fato que iremos retomar no que diz respeito à elaboração de sua obra e sua crítica de arte no decorrer do nosso projeto.

(...) Deformei, ninguém não imagina quanto, a minha obra - o que não quer dizer que si não fizesse isso, ela seria milhor. Abandonei, traição consciente, a ficção, em favor de um homem-de-estudo que fundamentalmente não sou. Mas é que eu decidira impregnar tudo quanto fazia de um valor utilitário, um valor prático de vida, que fosse alguma coisa mais terrestre que ficção, prazer estético, a beleza divina.

Mas eis que chego a este paradoxo irrespirável: tendo deformado toda a minha obra por um anti-individualismo dirigido e voluntarioso, toda a minha obra não é mais que um hiper-individualismo implacável! E é melancólico

\footnotetext{
${ }^{14}$ BOSI, Alfredo. História Concisa da Literatura Brasileira. Ed. Cultrix, São Paulo, $3^{a}$ ed., p. 392.
} 
chegar assim no crepúsculo sem contar com a solidariedade de si mesmo". (ANDRADE, [1942], 2002, p. 279)

Enquanto artista e crítico participante do projeto de atualização de "nossa Inteligência nacional", Mário de Andrade analisa o modernismo brasileiro por meio do entrecruzamento de fatores econômico-sociais e de atividades artísticas e culturais promovidas por "um grupinho de intelectuais paulistas" que, se por um lado traziam características provincianas de uma elite aristocrática cafeeira e de uma burguesia industrial, por outro, tinham condições de viabilizar e atualizar o país estabelecendo um contato "espiritual" e "técnico" que o colocava em consonância com as vanguardas européias ${ }^{15}$. Segundo Andrade,

(...) o movimento modernista era nitidamente aristocrático. Pelo seu caráter de jogo arriscado, pelo seu espírito aventureiro ao extremo, pelo seu internacionalismo modernista, pelo seu nacionalismo embrabecido, pela sua gratuidade antipopular, pelo seu dogmatismo prepotente, era uma aristocracia de espírito. Bem natural, pois, que a alta e a pequena burguesia o temessem. (ANDRADE, [1942], 2002, p. 259)

\section{Daí resulta a relação entre o artista e o intelectual vinculado a uma aristocracia decadente ${ }^{16}$ que, ao estimular a ruptura com uma estética acadêmica}

\footnotetext{
15 "E, socialmente falando, o modernismo só podia mesmo ser importado por São Paulo e arrebentar na província. Havia uma diferença grande, já agora menos sensível, entre Rio e São Paulo. O Rio era muito mais internacional, como norma de vida exterior. Está claro: porto de mar e capital do país, o Rio possui um internacionalismo ingênito. São Paulo era espiritualmente muito mais moderna porém, fruto necessário da economia do café e do industrialismo conseqüente. Caipira de serra-acima, conservando até agora um espírito provinciano servil, bem denunciado pela sua política, São Paulo estava ao mesmo tempo, pela sua atualidade comercial e sua industrialização, em contato mais espiritual e mais técnico com a atualidade do mundo.

É mesmo de assombrar como o Rio mantém, dentro da sua malícia vibrátil de cidade internacional, uma espécie de ruralismo, um caráter parado tradicional muito maiores que São Paulo. (...) Como Belém, o Recife, a Cidade de Salvador: o Rio ainda é uma cidade folclórica" . ANDRADE, Mário. "O Movimento Modernista". In: Aspectos da Literatura Brasileira. 6. ed. Editora Itatiaia, 2002. X, p. 258-259.

16 "A Semana de Arte Moderna, ao mesmo tempo que coroamento lógico dessa arrancada gloriosamente vivida (desculpem, mas, éramos gloriosos de antemão...), a Semana de Arte Moderna dava um primeiro golpe na pureza de nosso aristocracismo espiritual. Consagrado o movimento pela aristocracia paulista, si ainda sofríamos algum tempo ataques por vezes cruéis, a nobreza regional nos dava mão forte e...nos dissolvíamos em favores da vida. Está claro que não agia de caso pensado, e si nos dissolvia era pela própria natureza e o seu estado de decadência. Numa fase em que ela não tinha mais nenhuma realidade vital, como certos reis de agora, a nobreza rural paulista só podia nos transmitir a sua gratuidade. Principiou-se o movimento dos
} 
e européia, e promover a busca de uma identidade artística e nacional, contribuiu para uma profunda modificação em nossa visão sobre a realidade brasileira, na qual, segundo Mário de Andrade, instaurou no país o "direito permanente à pesquisa estética; a atualização da inteligência artística brasileira e a estabilização de uma consciência criadora nacional".

Se tomarmos essas contribuições como fruto do que foi o modernismo no Brasil, somos levados a questionar quais eram então as condições da arte e da sociedade, bem como quais caminhos se entrecruzaram por elas para que resultassem nessas conquistas. Ainda nos pautando nas considerações traçadas em O Movimento Modernista, verificamos que Mário de Andrade atribui o caráter de inovação do Modernismo brasileiro à possibilidade de pesquisa estética, à atualização da inteligência brasileira, bem como à consciência criadora nacional por terem ocorrido de maneira conjugada, como um todo orgânico na consciência coletiva da nossa sociedade.

No entanto, há a importância em ressaltarmos novamente que este olhar crítico feito em retrospectiva é capaz de traçar tais considerações devido às constantes reavaliações que o autor faz de sua obra, como também à capacidade de análise sobre o período modernista, até o ano da conferência em questão, devido às convulsões artísticas e sociais da época.

O período iniciado pela exposição de Anita Malfatti seria aquele que o autor denomina como nosso Modernismo "heróico", devido ao caráter desinteressado, puro e livre no qual se encontrava o estado da arte (ANDRADE, [1942], 2002, p. 260). O iniciado com a Semana de Arte Moderna em 1922 seria o período "destruidor" do Modernismo, em que a idéia de ruptura com o academicismo anterior torna-se iminente, ao mesmo tempo que gratuita, devido dentre outras questões ao impulso de uma aristocracia já decadente.

E foi da proteção desses salões que se alastrou pelo Brasil o espírito destruidor do movimento modernista. Isto é, o seu sentido verdadeiramente específico. Porque embora lançando inúmeros processos e idéias novas, o movimento modernista foi essencialmente destruidor. Até destruidor de nós

salões. E vivemos oito anos, até perto de 1930, na maior orgia intelectual que a história artística do país registra". Ibidem, p.261. 
mesmos, porque o pragmatismo das pesquisas sempre enfraqueceu a liberdade de criação. (ANDRADE, [1942], 2002, p. 263)

Essa ruptura, que dá ensejo ao "caráter destruidor" do modernismo, é de maneira dialética responsável por aquilo que Mário de Andrade irá caracterizar como uma das conquistas deste período, que é a da atualização da inteligência artística nacional. Se relembrarmos as teorias de arte traçadas no Prefácio Interessantíssimo e A escrava que não é Isaura, e compararmos com as afirmações contidas no Movimento Modernista, podemos verificar que o autor amplia neste texto seu conceito sobre arte. Para além da liberdade necessária à pesquisa estética, ou seja, o estudo em relação à forma, à técnica e as representações possíveis que abarcam a beleza, a arte deve ser interessada na vida, e por isso desenvolver uma funcionalidade social (ANDRADE, [1942], 2002, p. 276). A relação entre forma e conteúdo na expressão artística é colocada em confronto por este modernista:

A prova mais evidente desta distinção é o famoso problema do assunto em arte, no qual tantos escritores filósofos se emaranharam. Ora, não há dúvida nenhuma que o assunto não tem a menor importância para a inteligência estética. Chega mesmo a não existir para ela. Mas a inteligência estética se manifesta por intermédio de uma expressão interessada da sociedade, que é a arte. Esta é que tem uma função humana, imediatista e maior que a criação hedonística da beleza. E dentro desta funcionalidade humana da arte é que o assunto adquire um valor primordial e representa uma mensagem imprescindível. Ora, como atualização da inteligência artística é que o movimento modernista representou papel contraditório e muitas vezes gravemente precário. (ANDRADE, [1942], 2002, p. 276)

O último período seria o iniciado em 1930 e denominado como de "construção", no qual muitos dos artistas e intelectuais se envolveram com a política, com a formação do Partido Democrático e como isso repercute uma nova atitude na Inteligência brasileira:

(...) uma fase mais calma, mais modesta e quotidiana, mais proletária, por assim dizer, de construção. (ANDRADE, [1942], 2002, p. 265) 
Aqui é interessante ressaltarmos os adjetivos atribuídos por Andrade a cada uma dessas fases, como "heróico", ao período mais "ingênuo" de experimentação estética, "destruidor" para o período de atuação das vanguardas contra a estética passadista - em que as preocupações formais se sobrepõem às de conteúdo - e "construtivo" referindo-se ao momento em que ocorre o contrário - ou seja, o conteúdo das manifestações artísticas são mais politizados, enquanto a experimentação formal atinge certa "estabilidade". Tais denominações acabam por atribuir ao Modernismo algumas características advindas do Romantismo, se observarmos que ambos movimentos se diferenciam das demais épocas da cultura brasileira pelo fato de serem responsáveis por um espírito revolucionário no campo da criação estética, conforme Mário de Andrade.

A idéia de revolução nos parece então mais ligada aos aspectos estéticos que ideológicos, no entanto, esta afirmação só poderá ser verificada nos capítulos subseqüentes, dos quais retiraremos nosso olhar do lado analítico deste artista e crítico, para nos concentrarmos nos interstícios de suas obras.

Resta-nos no entanto a seguinte questão: qual seria então o papel desempenhado por Mário de Andrade durante esse período das vanguardas que foi proeminente e destruidor? O que foi feito de sua obra para que Ihe restasse a sensação de "deformação" e "hiperindividualismo", não alcançando assim o estado de liberdade tão almejada? ${ }^{17}$ Teria a teoria para o intelectual se sobreposto, ou se distanciado, da práxis do artista?

No Peru, o Modernismo emerge com a finalidade de romper com as influências coloniais espanholas ainda fortemente presentes na sua realidade econômica, social e cultural. Divergente historicamente do brasileiro, no entanto nele se mantém o desejo antiacadêmico, bem como o espírito nacionalista do movimento. Conforme Mirko Lauer, a vanguarda peruana tem início a partir de 1920, com expressões exclusivamente poéticas que não chegaram a configurar

17 "Será que a liberdade é uma bobagem?...Será que o direito é uma bobagem!...A vida humana é que é alguma coisa a mais que ciências, artes, profissões. E é nessa vida que a liberdade tem um sentido, e o direito dos homens. A liberdade não é um prêmio é uma sanção. Que há-de vir". ANDRADE, op. cit., p. 280. 
um movimento literário. A narrativa peruana se desenvolve com o realismo a partir de 1930, e nas artes plásticas não se tem uma representatividade pictórica de vanguarda contundente, passando do regionalismo paisagístico do início do século para a exploração da figura do indígena a partir de 1919, tendo José Sabogal como um artista que se distingue neste período ${ }^{18}$.

Concomitante à obra poética de alguns autores proeminentes como César Vallejo, Martín Adán, Carlos Oquendo de Amat, entre outros, um importante meio característico das vanguardas estético-literárias desse momento são os periódicos, que atuam de modo significativo no Peru e se tornam difusores político-culturais, possuem uma instância coletiva, no qual se expressam diferentes vozes, possibilitando um novo tipo de discurso. Muitas foram as revistas desta fase, dentre as quais podemos citar a revista cusquenha Kosko (1924), La Prensa, El Tiempo, Variedades, Mundial, Amauta.

Ao observarmos o entrecruzamento de discursos gerados nesse veículo literário, seu caráter de produção coletiva, de debates entre diferentes vozes e idéias, bem como sua maior circulação junto ao público leitor, seria interessante questionarmos sua função em relação ao papel do intelectual e do artista junto à sociedade. A partir dessa pergunta, inserimos então a figura de um de seus maiores propositores, que foi José Carlos Mariátegui. Para que possamos adentrar na obra deste autor seria importante antes conhecer um pouco do homem, para que - assim como em Mário de Andrade - possamos analisar posteriormente sua crítica sobre o papel do artista, intelectual e da obra de arte em sua época.

José Carlos Mariátegui, apesar de sua breve vida, é um homem de uma biografia bastante memorável. Nascido em Moquegua no ano de 1895, foi levado a Lima em 1902, para se curar de um golpe que atingiu seu joelho esquerdo, onde ficou internado na clínica Maison de Santé por três meses. Posteriormente permaneceu imobilizado por mais três anos. Durante esse tempo, sendo obrigado a abandonar a escola, lia avidamente livros e revistas de todos os tipos,

\footnotetext{
${ }^{18}$ LAUER, Mirko. Máquinas e palabras: la sonrisa internacional hacia 1927. In: PÖPPEL, Hubert. Las vanguardias literárias em Bolívia, Colômbia, Ecuador, Perú. Biografia y antologia crítica. Madrid / Frankfurt: Iberoamericana / Vervuert 1999, p. 169.
} 
comportamento este que contribuiu para o início de sua formação como autodidata. Foi criado em uma família de formação religiosa cristã, com recursos financeiros escassos, o que o levou a trabalhar aos quatorze anos de idade, ingressando no jornal La Prensa ${ }^{19}$.

Neste período José Carlos Mariátegui passa a conviver com o círculo de escritores de La Prensa, entre os quais Abrahan Valdelomar, Alberto Hidalgo, Alberto Guillén e José Galvez. Dos debates travados entre esses colaboradores na redação do jornal, Mariátegui adquire suas primeiras influências intelectuais ${ }^{20}$, bem como entra em contato com a literatura de Ricardo Palma (1833-1919) autor das Tradiciones Peruana - e Manuel González Prada (1848-1918), tendo este último o influenciado fortemente, devido à postura revolucionária que manteve frente à literatura e à cultura, às questões indígenas e na crítica ao sistema político peruano. Nesse contexto, Mariátegui começa a escrever suas primeiras crônicas, utilizando o pseudônimo de "Juan Croniquer", bem como alguns outros pseudônimos - "El joven H", "Sigfrido"... - criados para contribuir com artigos para diferentes periódicos e revistas como Mundo Limeño, El Turf, Lulú e Colónida (TAURO, 1987, p.21-24). Nestes escreve sobre os mais diversos tipos de assuntos, nos mais distintos gêneros: crítica artística e teatral, comentários sobre assuntos políticos e de interesse local, crônicas policiais e "poesias elegantes" sobre os acontecimentos hípicos (TAURO, 1987, 19-21). Em 1917 ganha um concurso literário com a crônica "La procesión tradicional" junto com Julio Baudion e é autor de algumas peças teatrais como Las Tapadas e La mariscala, sendo esta última escrita em parceria com Abraham Valdelomar (1888-

\footnotetext{
19 "Allí lo esencial de su trabajo era un deleite para él; consistía en leer los originales de redactores y coloboradores, escritos a mano por lo general, a los cajistas, pues en aquel entonces aún no había linotipistas; razón por la cual, la lectura tenía que ser(¿) lenta y, por lo mismo, provechosa.De este modo, empezó a familiarizarse con las ideas y la literatura del pensador Rodó; del cronista Gómez Carrillo, del poeta Luis Benjamín Cisneros, del periodista y maestro Ulloa". BAZÁN, Armando. Mariátegui y su tiempo. In: BAZAN, Armando. Mariátegui y su tiempo. $10^{\mathrm{a}}$ ed. Lima, Editora Amauta, 1987, p. 15.

${ }^{20}$ Segundo Alberto Tauro, Mariátegui foi "movido entonces por los coloquios de la redacción y su insaciable avidez de conocimentos, se familiarizó con la literatura peruana y frecuentó la lectura de los clásicos y los modernos escritores españoles; disfrutó la agudeza y las sugestivos cuadros de la sociedad en las obras representativas de la cultura francesa; y quedó seducido por las complejidades psicológicas y los desgarramientos humanos que magistralmente describen los grandes escritores rusos y escandinavos". TAURO, Alberto. Escritos juveniles: La edad de piedra. Lima. Editora Amauta; 1987, p. 17.
} 
1919). Conforme La Prensa foi tomando uma direção voltada à política de direita, Mariátegui deixa o jornal e passa a colaborar com El Tiempo. Em 1918, participa da Comissão organizadora do Partido socialista e funda junto com César Falcón e Félix Del Valle a revista Nuestra Época ${ }^{21}$. A partir desse momento, declara publicamente a mudança de seu estilo, abandona o pseudônimo de Juan Croniquer e assume uma nova posição socialista, característica marcadamente presente em La Razón. Este jornal, do qual Mariátegui é um dos seus editores, foi publicado a partir de 1919, declarando apoio à reforma universitária, às reivindicações operárias e levantando críticas veementes contra o governo de Augusto Leguía, então candidato à presidência do Peru pelo Partido Nacional Democrático Reformista.

En este último diario patrocinamos la reforma universitaria. Desde 1918, nauseado de política criolla me orienté resueltamente hacia el socialismo, rompiendo con mis primeros tanteos de literato inficionado de decadentismo y bizantinismo finiseculares, en pleno apogeo. (MARIÁTEGUI, 1972)

Nesta primeira fase de formação - posteriormente denominada por Mariátegui como sua "Idade da pedra"- temos ainda um escritor dividido entre a necessidade de subsistência e o desejo de expressão intelectual (TAURO, 1987, p. 25).

Si yo me gobernara, en vez de que me gobernara la miseria del medio, yo no escribiría diariamente, fatigando y agotando mis aptitudes, artículos de periódico. Escribiría ensayos artísticos o científicos más de mi gusto. (MARIÁTEGUI, 1987, p. 25)

Como decorrência podemos dizer que durante esta época Mariátegui desenvolve um estilo crítico-literário orgânico, compreendido entre seu aprendizado teórico e seu desenvolvimento prático, entre a experiência da crítica

\footnotetext{
${ }^{21}$ Segundo Luis Bernardo Pericás, Nuestra Época é uma revista "inspirada na revista España, editada por José Ortega y Gasset e depois por Luis Araquistáin, não tem um programa definido, serve basicamente para divulgar as idéias de seus colaboradores e só chega o número dois". PERICÁS, Luiz B. Introdução: José Carlos Mariátegui e o marxismo. In: MARIÁTEGUI, José Carlos. Do sonho às coisas. Retratos subversivos. Trad., org., e notas Luis Bernardo Pericás. São Paulo: Boitempo, 2005, p.14.
} 
jornalística cotidiana e suas aspirações artísticas, o que acaba por contribuir com seus intuitos sociabilizantes e de uma escrita não automatizada.

Esta etapa termina com o golpe de Estado de Leguía (1919), com a proibição oficial da publicação de La Razón e com o exílio de Máriátegui na Europa $^{22}$, onde permanecerá de 1919 a 1923. Durante este tempo no velho continente, começa uma segunda fase bastante importante na vida de Mariátegui, pois é quando intensifica sua formação política e cultural, entrando em contato com o pensamento de Benedetto Croce, Piero Gobetti, Antonio Gramsci, D’Annunzio, Romain Rolland, Barbusse, Gorki, Georg Sorel, George Grosz; bem como viaja para França, Itália, Alemanha, Áustria, travando sempre contato com outros grandes homens e conhecendo alguns outros países ${ }^{23}$.

Residí más de dos años en Italia donde desposé una mujer y algunas ideas. Anduve por Francia, Alemania, Austria y otros países. Mi mujer y mi hijo me impidieron llegar a Rusia. (MARIATEGUI,1972)

Poderíamos dizer que uma terceira fase inicia-se na vida e obra de José Carlos Mariátegui a partir de 1923, ano de seu regresso ao Peru. Durante esse período, o qual corresponde aos últimos sete anos de sua vida, envolveu-se em diversas manifestações políticas, sendo membro da Aliança Popular Revolucionária Peruana - APRA (1926-1928) por meio do contato travado com seu fundador, Victor Raúl Haya de la Torre. Projeta a organização de uma central sindical dos trabalhadores peruanos (1926), funda o Partido Socialista do Peru (1928) e é eleito membro do Conselho Geral da Liga contra o imperialismo e pela independência dos povos (1929). ${ }^{24}$

Neste ínterim que precede sua morte, Mariátegui lança dois livros, La escena contemporánea (1925) - que é o resultado de uma série de palestras

\footnotetext{
22 "Nesse momento, Mariátegui recebe o convite para ir à Europa, para "servir" o governo peruano como agente de imprensa, o que seria, na prática, uma forma de exílio disfarçada. Leguía, viúvo de Julia Swayne e Mariátegui (prima-irmã do pai de Mariátegui), poderia ter ordenado a prisão do jovem periodista, mas, influenciado por Enrique Piedra e Fócion Mariátegui (tio de José Carlos), decide mandar o futuro teórico socialista para bem longe, achando que assim estaria resolvendo parte de seus problemas". PERICÁS, Luiz B., Op. cit., p. 17-18.

${ }^{23}$ MELIS, Antonio. "Mariátegui, primer marxista de América". In: Leyendo Mariátegui. Lima: Editora Amauta, 1999, p. 15.

${ }^{24}$ MELLIS, A. op. cit., p. 21.
} 
proferidas na Universidade Popular "González Prada" a respeito de sua experiência européia - e Siete Ensayos de Interpretación de la Realidad Peruana (1928). Nesta última obra vemos o intuito de Mariátegui em traçar uma perspectiva crítica sobre a história peruana, no que se refere aos problemas trazidos pela independência, a reforma agrária e os problemas do índio. Junto a essa perspectiva de análise econômico-social, o autor desenvolve um capítulo no qual constam ensaios nos quais analisa a literatura peruana, denominado El Proceso de la Literatura (MARIATEGUI, [1928], 1958, p. 198). Nestes dois livros, organizados pelo próprio autor, como também no conjunto de outros textos organizados postumamente pela família, a tematização cultural é constante, bem como as relações entre arte e política, denotando uma reflexão crítica em que tais fatores muitas vezes se inter-relacionam:

El espíritu del hombre es indivisible; y yo no me duelo de esta fatalidad, sino, por el contrario, la reconozco como una necesidad de plenitud y coherencia. Declaro, sin escrúpulo, que traigo a la exégesis literaria todas mis pasiones e ideas políticas, aunque, dado el descrédito y degeneración de este vocablo en el lenguaje corriente, debo agregar que la política es mí filosofía y religión.

Pero esto no quiere decir que considere el fenómeno literario o artístico desde puntos de vista extraestéticos, sino que mi concepción estética se unimisma, en la intimidad de mi conciencia, con mis concepciones morales, políticas y religiosas, y que, sin dejar de ser concepción estrictamente estética, no puede operar independiente o diversamente. (MARIÁTEGUI, Amauta, $n^{\circ} 1,1926$, p. 150)

Em fevereiro de 1926, Mariátegui organiza o boletim Líbros y Revistas, cuja publicação era feita pelas Ediciones Minerva, de propriedade de seu irmão Julio César Mariátegui. Esta revista é lançada com a finalidade de promover a cultura peruana, que segundo nota de seu editorial

Libros y Revistas estudiará y reseñará el movimiento literario contemporáneo. En sus comentarios y en sus noticias, reflejará, con toda la amplitud posible, el movimiento bibliográfico nacional y extranjero. (...) Libros y Revistas informará a su público sobre todas las instituciones, movimientos, corrientes, tendencias y grupos que costituyan una expresión 
interesante, del trabajo, o de la crisis, de la inteligencia. (Editorial Libros y Revistas, Ano I, Num. I)

\begin{abstract}
Este boletim passará a ser publicado junto à revista Amauta $^{25}$, periódico idealizado por Mariátegui desde seu retorno da Europa e que, no entanto, só foi lançado em setembro de 1926:
\end{abstract}

AMAUTA há tenido un proceso normal de gestación. No nace de súbito por determinación exclusivamente mía. Yo vine de Europa con el propósito de fundar una revista. Dolorosas viscisitudes personales no me perimitieron cumplirlo. Pero este tiempo no ha transcurrido en balde. Mi esfuerzo se ha articulado con el de otros intelectuales y artistas que piensan y sienten parecidamente a mí. Hace dos años, esta revista habría sido una voz un tanto personal. Ahora es la voz de un movimiento y de una generación. (MARIÁTEGUI, Amauta, nº 01, 1926)

De fato, Mariátegui, neste intervalo entre seu regresso da Europa e a criação da revista Amauta, volta a sofrer com sua saúde e em 1924 tem uma de suas pernas amputadas, passando a viver em uma cadeira de rodas.

Amauta tornou-se um dos periódicos mais importantes quanto à circulação de diferentes vozes de expressão e reflexão intelectual e espiritual da vanguarda peruana. A princípio esta revista, que deveria chamar-se Vanguardia $^{26}$ exatamente pelo caráter de renovação intelectual e artística que se buscava no Peru deste momento, recebe o nome que faz referência a uma figura simbólica da tradição indígena. Em quéchua Amauta significa o "sábio", "mestre", aquele responsável por sociabilizar conhecimentos. Essa denominação, que retoma a tradição indígena para valorizar as diferenças étnicas advindas com a colonização,

\footnotetext{
${ }^{25}$ Segundo Alberto Tauro, Libros y Revistas "apareció en febrero de 1926; su segundo número correspondió a marzo y abril del mismo año; desde el tercero hasta el décimo octavo, aparecen incluídos en Amauta, pero conservando su propio número de orden; y en adelante, o sea, a partir del número 17 de Amauta, aparece incorporado al cuerpo de la revista, como sección bibliográfica. Según su estructura original, Libros y Revistas contenía: un reportaje literario, fragmentos de obras importantes y comentarios críticos. Fue un innegable antecedente editorial de Amauta." In: TAURO, Alberto. Noticia de "Amauta". Revista Amauta: revista mensual de Doctrina, Literatura, Arte, Polemica. Edicion en Facsímile; Lima; Empresa Editora Amauta S.A., p. 13

26 "Vuelvo a un querido proyecto detenido por mi enfermedad: la publicación de una revista crítica, Vanguardia, revista de los escritores y artistas de vanguardia del Perú y Hispanoamérica".
} 
será tema de debate para essa revista que volta seu olhar para o passado, a tradição advinda da comunidade indígena, para daí abstrair o novo.

Esta revista, en el campo intelectual, no representa un grupo. Representa, más bien, un movimento, un espíritu. En el Perú se siente desde hace algún tiempo una corriente, cada día mas vigorosa y definida, de renovación. A los fautores de esta renovación se les llama vanguardistas, socialistas, revolucionarios etc. La historia no los ha bautizado definitivamente todavía. Existen entre ellos algunas discrepancias formales, algunas diferencias psicológicas. Pero por encima de lo que los diferencia, todos estos espíritus ponen lo que los aproxima y mancomuna: su voluntad de crear un Perú nuevo dentro del mundo nuevo. La inteligencia, la coordinación de los más volitivos de estos elementos, progresan gradualmente. El movimiento - intelectual y espiritual - adquiere poco a poco organicidad. Con la aparición de "Amauta" entra en una fase de definición. (MARIÁTEGUI, Amauta, 1926, nº 01)

Em junho de 1927 Amauta será fechada devido às constantes críticas difundidas sobre a situação do Peru durante o governo de Augusto B. Leguía. Mariátegui, acusado de complô comunista, foi preso no Hospital Militar de Lima. Em dezembro de 1927 esta Revista será relançada chegando a completar, em setembro de 1928, dois anos de existência. É quando Mariátegui publica, em resposta às perseguições até então sofridas, um texto polêmico em seu editorial, chamado Aniversario y Balance, em que reafirma o compromisso e o intuito revolucionário desta revista, pautada num socialismo indo-americano.

El socialismo no es, ciertamente, una doctrina indo-americana. Pero ninguna doctrina, ningún sistema contemporáneo lo es ni puede serlo. Y el socialismo, aunque haya nacido en Europa, como el capitalismo, no es tampoco específica ni particularmente europeo. Es un movimiento mundial, al cual no se sustrae ninguno de los países que mueven dentro de la órbita de la civilización occidental. Esta civilización conduce, con una fuerza y unos medios de que ninguna civilización dispuso, a la universalidad. Indo América, en este orden mundial, puede y debe tener individualidad y estilo; pero no una cultura ni un sino particulares. Hace cien años, debimos nuestra independencia como naciones al ritmo de la historia de Occidente, que desde la colonización nos impuso ineluctablemente su compás. 
Libertad, Democracia, Parlamento, Soberanía del Pueblo, todas las grandes palabras que pronunciaron nuestros hombres de entonces, procedían del repertorio europeo. La historia, sin embargo, no mide la grandeza de esos hombres por la originalidad de estas ideas, sino por la eficacia y genio con que las sirvieron. $Y$ los pueblos que más adelante marchan en el continente son aquellos donde arraigaron mejor y más pronto. La interdependencia, la solidaridad de los pueblos y de los continentes, eran sin embargo, en aquel tiempo, mucho menores que en éste. El socialismo, en fin, está en la tradición americana. La más avanzada organización comunista, primitiva, que registra la historia, es la inkaica. (MARIÁTEGUI, Amauta, 1928, nº 17)

Amauta terá seu último exemplar lançado em 1930, ano em que morre seu editor. Durante estes últimos anos, Mariátegui também dirigiu o jornal Labor (19281929), publicação esta que durou onze números e era voltada às causas do proletariado.

Até aqui tomamos a voz de Mariátegui para levantarmos algumas questões que giraram em torno do autor, quanto à sua vida e obra. Há ainda que salientarmos algumas indagações que nos restam para a análise de seu projeto estético-ideológico, referentes ao pensamento da posição do artista e ao contexto contemporâneo da época.

A relação entre a forma e o conteúdo de uma obra de arte, para Mariátegui, não é possível existir sem se inter-relacionar, sem que o valor atribuído a um e outro signo tenha o mesmo significado. No texto Arte, Revolución y Decadencia ${ }^{27}$, Mariátegui entende que na época contemporânea às vanguardas artísticas, seja a européia, seja a da reapropriação pelas vanguardas peruanas, há artistas "jovens" que, por incompreensão do momento social e político ao qual estão inseridos seja pela ideologia, ou ausência de ideologias que os movem - acreditam que o

27 MARIÁTEGUI, José Carlos. "Arte, Revolucion y Decadencia". In:Revista Amauta: revista mensual de Doctrina, Literatura, Arte, Polemica. Edicion en Facsímile; Lima; Empresa Editora Amauta S.A.,1926, p. 03-04. 
novo possa emergir apenas de uma revolução estética, na qual sobrepõem o trabalho técnico e da linguagem, sobre o conteúdo das obras.

Una técnica nueva debe corresponder a un espíritu nuevo también. Si no, lo único que cambia es el paramento, el decorado. $Y$ una revolución artística no se contenta de conquistas formales. (MARIÁTEGUI, Amauta, 1926, no 03, p. 3)

Junto ao fenômeno do novo proposto pelas vanguardas, o autor irá observar a ascensão da burguesia capitalista, e daí constatar que, a este entrecruzamento sócio-econômico, formam-se espíritos voltados à revolução e outros à decadência. Para Mariátegui, a decadência está na arte que não se relaciona com a vida, junto a artistas que não compreendem suficientemente seu tempo, ou seja, que se desligam de toda e qualquer compreensão política sobre a sociedade. Com isso acabam por negar que possa existir uma arte puramente estética.

Vicente Huidobro pretende que el arte es independiente de la política. Esta aserción es tan antigua y caduca en sus razones y motivos que yo no la concebiría en un poeta ultraísta, si creyese a los poetas ultraístas en grado de discurrir sobre política, economia y religíon. Si política es para Huidobro, exclusivamente, la de Palais Bourbon, claro está que podemos reconocerle a su arte toda la autonomía que quiera. (MARIÁTEGUI, Amauta, 1926, no $03, p .3)$

Frente à decadência que representa o capitalismo e sua conseqüência nefasta ao espírito do homem, as vanguardas podem ser compreendidas como um movimento em dupla perspectiva, pois ao mesmo tempo que expressam uma arte cindida e desagregada, podem ser interpretadas em seu caráter de dissolução como reflexo do novo que está para surgir. Para Mariátegui, então, as vanguardas representam um sintoma de um mundo em crise, no qual coabitam ao mesmo tempo o espírito da revolução e da decadência.

La decadência y la revolución, así como coexisten en el mismo mundo, coexisten también en los mismos indivíduos. La conciencia del artista es el circo agonal de una lucha entre los dos espíritus. La comprensión de esta 
lucha, a veces, casi siempre, escapa al propio artista. (MARIÁTEGUI, Amauta, 1926, $\mathrm{n}^{\circ}$ 03, p.3)

Neste sentido Mariátegui discorda das afirmações de Ortega y Gasset sobre o caráter de desumanização da arte junto às vanguardas. Estas não refletem a degradação dos valores humanos e artísticos, mas sim um momento de transição, um momento em que da crise se elaboram elementos do que está por vir, os quais Mariátegui denomina como elementos que contribuem para o "amanhecer" de uma nova era. Aqui poderíamos até mesmo dizer que as vanguardas representariam então o momento de revolução, ao mesmo tempo que de possível construção de um novo homem, de uma nova arte, de uma outra época.

El cubismo, el dadaísmo, el expresionismo, etc., al mismo tiempo que acusan una crisis, anuncian una reconstrucción. Aisladamente cada movimiento no trae una fórmula; pero todos concurren - aportando un elemento, un valor, un principio -, a su elaboración. (MARIÁTEGUI, Amauta, 1926, nº 03, p.3)

A partir das vozes destes autores, Mário de Andrade e José Carlos Mariátegui, sobre a avaliação que fizeram de suas vidas e obras, bem como sobre a compreensão que teceram entre a função da arte junto às vanguardas brasileiras e peruanas, observamos que a idéia de revolução artística ocorre não apenas por meio do caráter e perspectiva romântica atribuídas ao movimento das vanguardas, mas também pela práxis de suas atuações como intelectuais. O projeto estético-ideológico configurar-se-á através de suas atividades como intelectuais, através de suas vastas obras.

Tentaremos nos próximos capítulos averiguar os conceitos que pairam sobre alguns movimentos artísticos, bem como a difusão desses em relação ao contexto latino-americano. Com isso poderemos refletir sobre como se formaram e se transformaram as idéias elaboradas por Mário de Andrade e José Carlos Mariátegui em relação tanto à função do artista junto à sua época, quanto às suas próprias atuações como intelectuais. 


\section{Capítulo 2: A arte entre conceitos}

O cansaço intelectual é intermitente nas suas manifestações. Seu efeito quasi sempre periférico, epidérmico. Não prejudica ou modifica o pensamento, sinão a forma dentro da qual esse pensamento se manifesta. Nós pensamos idéias dos Araniaca, idéias de Tales de Mileto, idéias de Santo Agostinho, de Descartes, de toda a gente. A farinha em que o pensamento se amassa é a mesma. Os grãos tirados dos mastabas egípcios deram trigo igual ao argentino. O pão é que tem forma diferente.

(Mário de Andrade, A escrava que não é Isaura)

El arte es una evasión cuando el artista no puede aceptar ni traducir la época y la realidad que le tocan.

( José Carlos Mariátegui, Siete Ensayos de Interpretación de la Realidad Peruana )

Para adentrarmos no projeto estético e ideológico que norteia a crítica de Mário de Andrade e José Carlos Mariátegui, buscamos levantar alguns conceitos sobre os quais são "construídas" suas obras. A partir dessa perspectiva, procuramos verificar como também suas obras visam "construir" uma idéia de arte que viesse a influenciar a sociedade sobre o modo de pensar a cultura de seus países, seja o Brasil ou o Peru. Neste capítulo iremos partir de alguns conceitos desenvolvidos por estes dois autores, como a dicotomia entre a tradição e a modernidade, para assim observar que junto a esta idéia ocorrem outras que estarão presentes em suas formulações críticas, como: as relações entre o local e o universal, a aristocracia e a burguesia, bem como o papel individual ou coletivo do artista perante a sociedade. Partimos da primeira dualidade e, ao longo deste trabalho, verificaremos ao lado dos textos escritos por estes intelectuais como as demais categorias se desenvolvem em suas obras.

Para compreendermos o conceito de tradição e modernidade na crítica de Mário de Andrade e José Carlos Mariátegui é necessário que tomemos suas obras a partir de um intuito comum a ambos autores, que é o de colaborar com o desenvolvimento de uma arte que fosse vinculada à vida, e com isso, desempenhasse uma função social. Assim, o propósito de afirmar uma identidade 
nacional, tanto do brasileiro, como do peruano, se coloca como um dado diferenciador quanto às especificidades culturais destes países frente às vanguardas européias. Conforme aponta Raul Antelo, "abrasileirar o Brasil tem para Mário o mesmo sentido que peruanizar o Peru para Mariátegui." (ANTELO, 1986, p. 103).

Mário de Andrade e José Carlos Mariátegui voltam suas análises às origens autóctones e à mestiçagem, primeiramente, como forma de reconhecer através do elemento étnico os caminhos para se repensar a tradição de seus países. Por meio da idéia de caráter nacional, questionaram as diferenças que se interpunham entre uma civilização cuja expressão era formada sob bases tidas como "primitiva", em relação à civilização européia, "culta" e "civilizada", imposta principalmente aos países colonizados, como modelo a se seguir.

A necessidade de se refletir sobre o caráter primitivo do brasileiro é vista por Mário de Andrade, no Prefácio Interessantíssimo, como "uma nova fase construtiva" e que compete aos artistas e intelectuais "esquematizar, metodizar as lições do passado" (ANDRADE,1922, p. 29). Neste período, o autor está iniciando suas reflexões sobre um dos temas mais caros aos modernistas de 1922, que se refere à compreensão da "identidade brasileira". Se de início esta questão é vista somente no âmbito da estética, posteriormente será empregada em seu sentido revolucionário, como expressa o Manifesto Antropofágico (1928), de Oswald de Andrade, através da irônica síntese: "Tupy, or not tupy that is the question".

Essa busca pelo caráter nacional engendra um olhar ao passado em relação à população indígena e ao processo de mestiçagem que se inicia com a chegada do europeu e do negro africano no continente, como também o processo de reconhecimento profundo da realidade brasileira. Para os modernistas, resgatar o passado não significa manter uma postura tradicionalista frente à realidade brasileira, mas sim reaver a tradição para a partir dela assumir uma identidade cultural que the seja própria, conforme depreendemos das palavras de Mário de Andrade: "o passado é lição para se meditar, não para se repetir" (ANDRADE, 1922, p. 35). Dessa idéia podemos dizer que se estabelece o conceito, por ele denominado como tradições móveis, no qual o passado não deve ser visto sob 
uma perspectiva estagnada, mas sim reconhecido e reformulado de acordo com sua época.

Nesta mesma direção encontramos as formulações de José Carlos Mariátegui sobre a importância da tradição para a formação do Peru de sua época. Para Mariátegui, a mentalidade colonialista propagada pelo dominador espanhol colocava o Império Incaico como pré-história do povo peruano. Assim, a retomada do autóctone para a história peruana era fundamental na elaboração de uma tradição peruana, pois, de acordo com suas palavras, o Peru "és todavia un concepto por crear"28. Dessa maneira o conceito de tradição empregado por Mariátegui deveria ser entendido - conforme expresso em seu texto Heterodoxia de la Tradicion - de maneira dialética, pois, diferentemente do que os tradicionalistas $^{29}$ desejavam, a tradição deveria ser tomada como elemento "vivo", "móvel", como "patrimônio e continuidade histórica". São esses os preceitos, para este autor, que engendram a força da tradição em seu sentido revolucionário.

A tradição nos parece assim parte fundamental das formulações críticas que Mário de Andrade e José Carlos Mariátegui iriam desenvolver em suas concepções sobre a modernidade. Podemos analisar o paradoxo entre as épocas - da tradição e da modernidade - através do que Octavio Paz chamou de "a tradição do moderno". Nesta perspectiva, as contradições entre o antigo e o novo, o moderno e o tradicional, o passado e o presente, encerram-se frente à simultaneidade dos tempos e dos espaços da época moderna. Além das incursões deste autor sobre o conceito de tempo - presente, passado e futuro ser distinto para cada civilização, chama-nos em especial a atenção aquilo que

\footnotetext{
${ }^{28}$ Mariátegui emprega neste trecho uma frase de Waldo Frank que se refere ao modo como este avalia o processo que também vinha sofrendo a América do Norte. MARIÁTEGUI, José Carlos. "La Tradición Nacional". In: Peruanicemos al Perú. Lima: Empresa Ed. Amauta, 1970, tomo 11, p. 121.

29 "No hay que identificar a la tradición con los tradicionalistas. El tradicionismo - no me refiro a la doctrina filosófica sino a una actitud política o sentimental que se resuelve invariablemente en mero conservantismo - es, en verdad, el mayor enemigo de la tradición. Porque se obstina interesadamente en definirla como un conjunto de reliquias inertes y símbolos extintos. $\mathrm{Y}$ en compendiarla en una receta escueta y única." MARIÁTEGUI, José Carlos. "Heteredoxia de la tradición". Op. cit., p. 118.
} 
Octavio Paz define como "a tradição moderna", que para ele significa o momento em que passamos a ter "consciência histórica" sobre a realidade ${ }^{30}$.

Al cambiar nuestra imagen del tiempo, cambió nuestra realción con la tradición. Mejor dicho, porque cambió nuestra idea del tiempo, tuvimos consciencia de la tradición. Los pueblos tradicionalistas viven inmersos en su pasado sin interrogarlo; más que tener conciencia de sus tradiciones, viven con ellas y en ellas. Aquel que sabe que pertenece a una tradición se sabe ya, implícitamente, distinto de ella, y ese saber lo lleva, tarde o temprano, a interrogarla y, a veces, negarla. La crítica de la tradición se inicia como conciencia de pertenecer a una tradición. (PAZ, 1974, p. 2425)

A revisão do conceito de tradição como elemento fundamental para a concepção da modernidade brasileira e peruana, tanto a Mário de Andrade como em José Carlos Mariátegui, seria um assunto menos importante - visto que a tradição era um tema fundamental para grande parte do modernismo nos países latino-americanos - se não trouxesse dados tão ricos para nosso estudo comparado: o da relação entre dois intelectuais que pretendiam atuar, de maneira consciente, com uma prática literária que, ao retomar o passado, visava influenciar a formação histórica e cultural da sociedade. Tomando de empréstimo as palavras de Alejandro Losada $^{31}$, em suas análises sobre a práxis literária, e se concordarmos que "las formas literárias son expresión de las formas de consciencia que tiene el hombre de sus formas de existencia en el mundo", poderemos verificar como estes autores, mesmo fazendo parte de contextos e momentos diferentes, se encontraram quanto às leituras que realizaram junto aos livros e revistas da época, através de alguns autores que mais admiraram, pela visão de mundo que a partir delas formaram, com isso dando "formas" e "sentido" às suas próprias escritas.

\footnotetext{
${ }^{30}$ PAZ, Octavio. Los Hijos del Limo:del Romanticismo a laVanguardia. Barcelona: Ed. Seix Barral, 1974 , p. 15-25.

31 LOSADA, Alejandro. Creación y Praxis. La producción literaia como praxis social en Hispanoamérica y el Perú. Lima, Universidad Nacional Mayor de San Marcos, 1976, p.139.
} 
Ao percorrermos os caminhos destes intelectuais quanto ao conceito de tradição e modernidade, verificamos através de seus textos que algumas obras e autores lidos por Andrade e Mariátegui coincidem, tanto em relação às teorias que propõem, quanto em relação às reflexões, por parte desses críticos, sobre sua "pertinência" conceitual ou não. Dessas leituras abordaremos neste capítulo uma em especial que nos parece bastante importante quanto ao critério moderno que propõe para a observação e estruturação crítica de formação e análise da literatura latino-americana.

Em torno de 1925, Mário de Andrade lê em Europe - um periódico de arte que possuía uma seção voltada às Américas - a teoria de um crítico norteamericano sobre a literatura deste país, cujo tema aborda o nacionalismo como expressão da modernidade. De acordo com Telê Porto Ancona Lopez, Andrade neste período intentava criar uma cultura brasileira, apoiando-se na pesquisa de teorias que revelassem não somente uma análise profunda e de amplo enfoque cultural - e não apenas estético -, mas que também demonstrasse, na prática, a eficiência destas teorias (ANCONA LOPEZ, 1972, p. 203). Ainda de acordo com suas palavras, apesar de Mário de Andrade, no momento em que lê este artigo, ainda ver o nacionalismo como uma etapa de auto-conhecimento, este autor...

Vê na posição do crítico norte-americano, o nacionalismo literário, uma identidade de caminhos com o Modernismo brasileiro, principalmente porque o autor englobara o sentido de objetividade da crítica social traçada por Waldo Frank. (ANCONA LOPEZ, 1975, p. 204).

Vale a pena transcrever parte deste artigo como ponto de reflexão e posterior comparação, pois este nos parece bastante relevante para observarmos como o nacionalismo é repensado para a América do Norte e como é orientado na obra dos autores que nos propomos a analisar.

Nesse artigo, Gorham B. Munson - autor do texto - tem como finalidade refletir sobre as possibilidades de se estabelecer um método pelo qual se possa analisar e caracterizar os processos literários. Para tanto, retoma parte de suas análises sobre a literatura norte-americana em que a dividia em três fases - a era 
de Emerson, a era de Whitman e a era do Nacionalismo. De acordo ainda com suas palavras, esta última fase corresponderia à elaboração do período moderno, e estava ainda por se configurar. Para chegar a esta classificação Munson correlaciona os processos literários às etapas de uma fórmula matemática, na qual junto às equações introduz-se um "fator indeterminável", capaz de "multiplicá-las misteriosamente". Este fator é conhecido como "ponto singular". Em literatura, segundo Munson, o "ponto singular" capaz de modificar e "multiplicar as equações" literárias está na figura do "gênio". Transpondo este método a outros que fossem mais recentes e possíveis de serem aplicados à literatura norteamericana, o autor ressalta o método do "comum", o qual também distinguia três fases aos processos literários. Este método, por sua vez, irá consistir na observação não mais da elite do pensamento e da sensibilidade, mas nos elementos que caracterizavam a normalidade culta de uma nação.

Mediante as anotações marginais de Andrade, podemos verificar, por seus grifos, que the chama especialmente atenção a separação das três fases desenvolvidas por um estudioso de Harvard, citado por Munson, chamado Munsterburg, que levanta a hipótese sobre a necessidade de a cultura americana passar pela fase colonial ou provincial, pela fase do cosmopolitismo e pela fase nacional ${ }^{32}$.

Outro dado a se ressaltar, sobre o artigo em questão, é sobre o processo de análise crítica desenvolvida por Gorham B. Munson junto a essa divisão dos períodos literários. Ao apontar os confrontos que pairam entre a produção literária de artistas e intelectuais da fase de transição entre a independência intelectual norte-americana em relação à dominação inglesa, Munson percebe que os autores e críticos por ele abordados denotam certa falta de "rigor do conhecimento" em suas produções literárias. Dessa forma o autor do artigo distingue algumas características importantes que valeriam como critério para a análise destas produções literárias, como o estudo sobre a estética, o humanismo,

\footnotetext{
${ }^{32}$ Reproduzimos aqui o trecho grifado por Mário de Andrade: "Feu Le professeur Mustemburg, de Harvard, a jadis déclaré qu'une culture doit passer par trois phases: $1^{\circ}$ la phase provinciale ou coloniale; $2^{\circ}$ la phase cosmopolite; $3^{\circ}$ la phase nationaliste. La méthode de "moyennes" confirme pour la littérature américaine, tout au moins - cette hypotèse." MUNSON, Gorhan B. Chronique américane. In: Europe, 31, Paris, ago., 1925, p.368.
} 
a análise psicológica e social. Dentre os autores, para este crítico, que se distinguem e que fazem parte de uma nova geração capaz de integrar a América do Norte ao mundo, destaca Waldo Frank, tanto por encontrar em sua obra as características por ele anteriormente apontadas, como pelo modo inteligente que vincula suas pesquisas à vida.

Qual a relação entre as teorias expostas neste artigo e as obras de Mário de Andrade e José Carlos Mariátegui? Raul Antelo, ao estabelecer alguns pontos que julga efetivos para se pensar uma intercomunicação entre estes dois autores, reconhece como um dos temas incomuns em suas obras críticas, exatamente este critério moderno de periodização literária nas três fases - colonial, cosmopolita e nacional (ANTELO, 1986, p. 159). Coloquemo-nos assim ao lado das obras destes autores, para daí avaliarmos a pertinência ou não de tal método.

Em Mário de Andrade não encontramos qualquer referência precisa a esta "análise moderna" para a periodização literária, nem mesmo encontramos qualquer citação sobre os três períodos levantados por Munson em seus artigos sobre crítica de arte. No entanto podemos dizer que alguns de seus textos nos revelam a tentativa de estabelecer um tipo de método de análise crítica sobre os procedimentos artísticos, que nos faz indagar sobre possíveis aproximações ao método do autor norte-americano, ainda que isto não tenha sido dito de maneira explícita pelo escritor brasileiro.

Segundo Leon Kossovitch, o texto sobre O Aleijadinho (1928), de Mário de Andrade, é bastante significativo para a crítica de arte nacional, pois procura apresentar-se como "objeto de meditação" para a análise artística. Dito deste modo, o texto parece colocar-se como um modelo, que por meio de sua própria estrutura, procura demonstrar um método rigoroso, que busca fundamentar o conhecimento necessário para uma análise crítica $^{33}$. Para este autor, Mário de Andrade emprega em suas obras críticas, como um todo, um método, mesmo que implícito, que visa vincular:

${ }^{33}$ KOSSOVITCH, Leon. "As artes plásticas: Mário de Andrade e seu método". In: Discurso. Ano I, n I, FFLCH; Universidade de São Paulo, 1971, p. 83. 
(...) a personalidade de um artista a seu meio histórico-social e dessa ligação (obtêm-se) as bases necessárias à interpretação formal e expressiva. (KOSSOVITCH, 1971, p. 83)

Tendo em vista este recorte que propõe Leon Kossovitch sobre as três categorias que embasam os textos de Andrade, correspondentes à análise histórico-social, à psicológica e à formal, podemos indagar como estas divisões se apresentam nos textos deste autor, e ainda qual a relação destas categorias com as propostas de Munson sobre a análise literária. É relevante que apontemos que este "método" em Mário de Andrade parece se estender a textos não só literários, mas também abarca a crítica deste autor referente a outras linguagens artísticas, como as artes plásticas, a música, dentre outros.

Em seu artigo, de 1928, sobre Antonio Francisco Lisboa (1730-1814), O Aleijadinho, verificamos como Mário de Andrade objetiva vincular este artista à história do período colonial brasileiro, a fim de transformá-lo em representante de uma expressão nacional. Segundo Andrade, o surgimento de uma manifestação artística e nacional ocorre a partir da segunda metade do século dezoito, quando a colônia deixa de sofrer influências políticas e econômicas da metrópole portuguesa, como também com a normalização do mestiço (ANDRADE, [1928], 1984, p. 11). A partir desta constatação, o autor irá traçar relações entre diferentes aspectos que influenciam na formação do "gênio" Aleijadinho: o meio histórico e social, o psicológico e o formal.

Ao tomarmos a primeira proposição, sobre o meio histórico e social, verificamos que Mário de Andrade irá ao longo do texto construir argumentações que visam analisar a realidade brasileira desvinculando-a da crítica até então pautada no olhar europeu ${ }^{34}$. Ao voltar-se à formação do mulato como uma etnia

\footnotetext{
34 "Me espanta mas é muito, ver a sinceridade mesquinha com que historiadores e poetas depreciam o mulato. Capistrano de Abreu, Oliveira Lima, obedecendo sem nenhuma revisão honesta, à quizília que já na Colônia os reinóis manifestavam contra os mulatos, deixaram páginas sobre isso que não correspondem a nenhuma verdade nem social, nem psicológica. Ultimamente ainda foi Graça Aranha que fez o mesmo numa página que me pareceu repulsiva em sua eloqüência romântica. Não fazem mais do que se escravizar a um vício reinol e europeu, que já levava Bougainville a desaplaudir as representações de brancaranas nos teatros do Rio de Janeiro, (...)." ANDRADE, Mário de. "O Aleijadinho". In: Aspectos das Artes Plásticas no Brasil. 3 ed. Belo Horizonte: Ed. Itatiaia, 1984, p. 15.
} 
que compõe a raça brasileira, descendente do branco português e do negro africano, irá questionar o lugar reservado a ele nesta "nova sociedade", uma vez que não se situa nem junto à atividade do senhor de terra, nem mais no trabalho como escravo:

Os mulatos não eram nem milhores nem piores que brancos portugueses ou negos africanos. O que eles estavam era numa situação particular, desclassificados por não terem raça mais. [...]. Livres, dotados duma liberdade muito vazia, que não tinha nenhuma espécie de educação, nem meios para se ocupar permanentemente. Não eram escravos mais, não chegavam a ser proletário, nem nada. (ANDRADE, [1928], 1984, p. 15-16)

Dessa maneira, Andrade iria buscar na representação artística a expressão da mestiçagem formada pelos mulatos, que se por um lado não era uma atividade dominante, contudo, em sua visão, era a manifestação do pensamento de uma raça brasileira que se impunha naquele momento ${ }^{35}$. Para o autor de $O$ Aleijadinho, tendo o mulato elementos africanos em sua origem, possui uma forte tendência para a linguagem musical e das artes plásticas.

Na música é que eles conseguiram se tornar manifestação permanente de arte americana, habanera, tango, lundu, samba, ragtime e jazz. Pela escultura chegaram mesmo a influenciar as artes européias contemporâneas. Os nossos mestiços do fim da Colônia glorificam a "maior mulataria", se mostrando artistas plásticos e musicais. Só bem mais tarde é que darão representações literárias notáveis. (ANDRADE, [1928], 1984, p. 14)

Ao estabelecer relações entre a origem africana do mulato, sua disseminação através de manifestações artísticas, que se repetem por diversos países na América Latina, e sua influência sobre a Europa, Mário de Andrade constrói a origem e a importância dessa etnia tanto no conjunto nacional, como também no "universal". No nacional, ao estabelecer uma idéia de tradição, pela história musical e plástica, e no universal, ao tornarem-se os mulatos culturalmente influentes nas artes européias. Neste trecho, pode-se dizer que

\footnotetext{
${ }^{35}$ ANDRADE, M. Op. cit., p. 14.
} 
Andrade questiona, a partir de uma visão "periférica", o conceito de "primitivo" empregado pelo Velho Mundo $^{36}$, em relação aos povos que não dominam a cultura da Europa "culta" 37 .

A mestiçagem como dado étnico será agora analisada e incorporada aos padrões estéticos e psicológicos, através das características formais da obra, e em decorrência da personalidade artística de quem a produz. Conforme as palavras de Andrade, a mestiçagem - representada neste artigo pela figura do mulato - não aparecerá apenas como elemento da raça brasileira, mas será também muito "irregular no físico e na psicologia": "Cada mulato era um ser sozinho, não tinha referência étnica com o resto da mulatada" (ANDRADE, [1928], 1984, p. 16).

Dessa maneira, no caso da arte mineira, estas "irregularidades" se sobressaíram em personalidades isoladas, em individualidades que se distinguiam perante as condições sociais, como é a que ocorre na obra de Aleijadinho:

Em verdade, na consciência daquela gente inda não tinha se geografado o mapa do imenso Brasil. Ambições, desilusões, nababias, quedas bruscas, estaduanismo, mal-estar fundo: era natural que brotasse uma alma com pouca prática da vida, cheia de arroubos assustados, se esquecendo de si mesma nas névoas da religiosidade supersticiosa, cujo realismo, quando aparecia, aparecia exacerbado pela comoção, longe do natural, dramático, expressionista, mais deformador que os próprios símbolos. E de fato não passou disso a Inconfidência. $E$ foi isso quase que a obra toda de escultor, do Aleijadinho. (ANDRADE, M., [1928], 1984, p. 21)

Mário de Andrade analisa a obra de Aleijadinho dividindo-a em duas fases: a fase mais plástica - a de Ouro Preto e São João d’El-Rei, que se caracteriza

\footnotetext{
36 "Me parece importante sobretudo evitar que lhe ajuntem à personalidade o epíteto de "primitivo". Primitivo por quê? Em relação a quê? Com a palavra vaga, que tanto pode significar primário como turtuveante iniciador de orientações estéticas novas, a gente salva a própria incompreensão e principalmente o medo das feiúras." ANDRADE, M. Op. cit., p. 23.

37 "E mesmo assim, si compararmos bem a atuação dos mulatos e a dos Fanfarrões Minesios, um Dão João VI, um Pedro I, uma Carlota Joaquina, os poetas coimbrões de Inconfidência, a Diretoria lisboeta da Companhia dos Diamantes, pra só lembrar casos salientes e históricos: será difícil decidir quem que tem alma de "mulato" entre esses portugas e brasilianos sem firmeza nenhuma de caráter. Mulatos, mais "mulatos" que os desrraçados mulatos da maior mulataria." ANDRADE, M. Op. cit., p. 16.
} 
pela "serenidade equilibrada e pela clareza magistral" - e a fase mais expressiva, de Congonhas - "mais gótica e expressionista" (ANDRADE, [1928], 1984, p. 36).

É curioso observarmos como essas fases são organizadas, pois Andrade nos parece tentar inserir a arte de Antonio Francisco Lisboa no contexto mais amplo, de caráter universal. Inicialmente, ao comparar a obra de Aleijadinho e de seu antecessor português, o engenheiro Pedro Gomes Chaves, irá demonstrar como da lição obtida com o estrangeiro, o escultor mineiro foi capaz de ultrapassála e tornar-se paradigma de um gênio nacional. Para isso distingue as obras do artista colonial brasileiro de qualquer "pecha de primitivo", tendo em vista ser ele instruído e tecnicamente bastante consciente do material com que trabalha. Conforme Mário de Andrade, se de início Aleijadinho surge imitando as obras do engenheiro português, logo passa a "genializá-las", criando um estilo próprio ${ }^{38}$.

Se voltarmos às fases citadas anteriormente, poderemos verificar que em relação às características em que subdivide a obra do escultor mineiro - quando a deformação da primeira é vista como um caráter mais "plástico" e na segunda, mais "expressivo" - Mário de Andrade irá apontar uma certa "evolução" em relação ao uso das escolas artísticas.

A obra de Aleijadinho será caracterizada entre tendências que vão de um "realismo raro" a um "deformador sistemático". Este processo, ultrapassando as lições barrocas, passa por um sentimento "às vezes renascentista", e freqüentemente "gótico" e "expressionista", acaba por colocar Antonio Francisco Lisboa como um criador que ultrapassa os limites impostos pela colônia.

Ele reinventava o mundo. O Aleijadinho lembra tudo! Evoca os primitivos itálicos, bosqueja a Renascença, se afunda no gótico, quasi francês por vezes, muito germânico quasi sempre, espanhol no realismo místico.(...) É

\footnotetext{
38 "O Aleijadinho, surgindo da lição de Pedro Gomes Chaves, vem genializar a maneira deste, criando ao mesmo tempo um típico de igreja que é a única solução original que jamais inventou a arquitetura brasileira. E o que tenho por absolutamente genial nessa invenção é que ela contém algumas constâncias mais íntimas, mais arraigadas e mais étnicas da psicologia nacional, é um protótipo de religiosidade brasileira. Esse tipo de igreja, fixado imortalmente nas duas Francisco de Outo Preto e São João d'El-Rei, não corresponde apenas ao gosto do tempo, refletindo as bases portuguesas da Colônia, como já se distingue das soluções barrocas luso-coloniais, por uma tal ou qual denguice, por uma graça mais sensual e encantadora, por uma "delicadeza" tão suave, eminentemente brasileiras." ANDRADE, M., Op. cit., p. 30.
} 
um mestiço, mais que um nacional. Só é brasileiro porque, meu Deus! aconteceu no Brasil. (ANDRADE, M., [1928], 1984, p. 42)

Assim, se de início à arte de Aleijadinho é atribuída a "pecha de primitiva", através da deformação plástica pode-se dizer que o artista chega a um tipo de expressão que lhe garante uma personalidade própria, pois deforma a "lição aprendida" com a metrópole portuguesa. A deformação pode ser entendida em $O$ Aleijadinho, segundo Leon Kossovitch, como a forma pela qual Mário de Andrade aponta o rompimento com o barroco europeu e instaura valores próprios à arte nacional ${ }^{39}$.

Até aqui podemos perceber que através da "personalidade do artista" Antonio Francisco Lisboa, o Aleijadinho - o "gênio" nacional -, Mário de Andrade empenha-se em argumentar sobre a "formação do artista"; sua distinção e superação, por meio da deformidade expressiva, em relação à influência do modelo português; o que o torna, por sua vez, representativo perante um período da história da arte brasileira. E com isso nos parece que se configura uma "fase colonial" brasileira, como prevê a proposta de divisão da literatura americana, no artigo anteriormente citado, do crítico norte americano Gorham B. Munson.

Afora este reconhecimento da técnica do artista mineiro como expressão máxima do período colonial, a "deformação" será uma característica constante nas análises de Mário de Andrade, que entra em contato com a estética expressionista no final de 1917, com a Exposição de Arte Moderna Anita Malfatti, realizada em São Paulo. Esta exposição tornara-se um "divisor de águas", que "encerrando o capítulo da arte acadêmica, abria o caminho da arte moderna"40. Anita Malfatti, retornando de seus estudos na Alemanha e nos Estados Unidos, realiza sua primeira exposição, com tendências expressionistas, tornando-se alvo de polêmicas que se iniciam com a ácida crítica de Monteiro Lobato, publicada no jornal O Estado de São Paulo e intitulada A propósito da exposição Malfatti.

\footnotetext{
39 "Abrasileirando o barroco português, o Aleijadinho leva a cabo a missão que deveria cumprir a vontade nacional, ou seja, exprimir a partir do dado luso a vontade amadurecida." Ibidem, p. 91.

${ }^{40}$ BATISTA, Marta Rossetti. Anita no tempo e no espaço: biografia e estudo da obra. São Paulo: Ed. 34; Edusp, 2006, p. 17.
} 
Poucos compreendiam naquele momento as tendências modernas dos quadros apresentados, inclusive Mário de Andrade, que escreve um artigo em defesa da pintora somente em $1921^{41}$. Os motivos para tal silêncio devem ser avaliados perante o conservadorismo artístico que pairava no Brasil ainda por esta época. A exposição de Anita Malfatti é a primeira manifestação artística moderna que ocorre em São Paulo e a partir dela se desencadeia a busca de atualização dos artistas brasileiros perante as vanguardas européias. Mário de Andrade irá quatro anos depois lançar seu primeiro livro de poesia modernista ${ }^{42}$, apontando em seu Prefácio Interessantíssimo os processos para a criação da arte moderna.

Escrever arte moderna não significa jamais para mim representar a vida atual no que tem de exterior: automóveis, cinema asfalto. Si estas palavras freqüentam-me o livro não é porquê pense com elas escrever moderno, mas porquê sendo meu livro moderno, elas têm nele sua razão de ser. (ANDRADE, 1922, P. 34)

Esta representação do mundo "exterior" e "interior" será, neste primeiro momento de reflexão modernista, vista por Mário de Andrade através da análise formal dos procedimentos artísticos ${ }^{43}$. Vejamos primeiramente quais os caminhos para a criação da arte moderna, para que depois possamos refletir sobre o meio no caso, a palavra - como signo de expressão.

Em Paulicéia desvairada, Andrade procura compreender os processos que levam o artista moderno a dar forma à Poesia. Como visto no capítulo I, quando o autor de o Prefácio Interessantíssimo traça os caminhos da inspiração, vemos que o "impulso lírico" é o responsável pela passagem do estado de inconsciência para o estado de consciência, que por sua vez é concretizada pela linguagem. A esta

\footnotetext{
${ }^{41}$ Oswald de Andrade foi o primeiro a defender Anita Malfatti, em um artigo intitulado "A exposição Anita Malfatti", publicado em 11 de janeiro de 1918, por ocasião do encerramento da exposição. No entanto este artigo não foi assinado, contendo apenas suas iniciais O. A.. O segundo artigo em defesa da pintora só foi publicado em novembro de 1920, escrito por Menotti Del Picchia, que não esteve presente na exposição de 1917/18. Conf. BATISTA, Marta Rossetti, Idem., p. 256-258.

${ }^{42}$ Paulicéia Desvairada parece ter sido escrito entre dezembro de 1920 a dezembro de 1921, conforme aponta sua edição fac-similar, mas só foi lançado em 1922.

${ }^{43}$ Conforme apontamos na Introdução deste trabalho, podemos refletir sobre a obra de Mário de Andrade dividindo-a na fase anterior a 1930, quando prevalece preocupações mais "formais" em sua obra e uma nova fase que se inicia após esta data. A análise sobre as mudanças de perspectiva de sua obra serão discutidas ao longo de nosso estudo.
} 
concepção do fazer artístico, o autor irá acrescentar em $A$ escrava que não é Isaura (1925) as necessidades das "leis estéticas". Dessa maneira, a liberdade advinda com o impulso lírico, somada às "fundamentações estéticas" e aos "meios de expressão" (sintetizados pela fórmula agora revisada, de Paul Dermée, Lirismo puro + Crítica + Palavra $=$ Poesia), passaram a fazer parte das condições necessárias para a elaboração da poesia moderna.

Uma vez que a arte se aproxima da vida, por intermédio da "inteligência do poeta, - o qual não mora mais numa torre de marfim recebe o telegrama no bonde, quando o pobre vai para a repartição, para a Faculdade de Filosofia, para o cinema" ${ }^{44}$, temos um novo conceito de beleza.

Até aqui podemos dizer que o suposto "método" empregado para a análise de O Aleijadinho começa a se configurar nas concepções modernistas de Mário de Andrade sobre a arte. A "verdade artística" dependerá da análise crítica, pautado no conhecimento estético; os meios de expressão, baseados no saber técnico sobre a linguagem artística empregada; a psicologia do artista, nas pesquisas sobre o inconsciente e sua atitude perante a arte, e finalmente o novo conceito de beleza, advindo da aproximação da arte com a vida.

Mário de Andrade irá fundamentar este seu conceito de beleza - que se encontra em o Prefácio Interessantíssimo e posteriormente em $A$ escrava que não é Isaura - distinguindo-a entre o Belo artístico e o Belo natural. O Belo artístico é entendido pelo escritor como uma criação humana, e por isso transitória, pois estará na maioria das vezes relacionado a uma questão de moda, enquanto o Belo natural é imutável ${ }^{45}$. Se o Belo artístico é uma criação humana, o assunto poético irá relacionar-se mais à experiência do artista, à sua impulsão lírica e livre, e portanto vinculado-se a seu contato com o mundo, do que propriamente ligado a temas poéticos, como ocorria com os impressionistas.

O poeta traduz em línguas conhecidas o eu profundo. Essa tradução se efetua na inteligência por um juízo, pelo que é na realidade em psicologia “associação de idéias". (ANDRADE, [1922-1925], 1980, p. 243)

\footnotetext{
${ }_{44}^{44}$ ANDRADE, M. "A escrava que não é Isaura". In: Obra Imatura, 1980, 3ed. p. 209.

45 "Quem procurar o Belo da natureza numa obra de Picasso não o achará. Quem nele procurar o Belo artístico, originário de euritmias, de equilíbrios, da sensação de linhas e de cores, da exata compreensão dos meios pictóricos, encontrará o que procura." Ibidem , p. 207.
} 
Porém a modernidade traz o confronto para o artista entre a observação da multiplicidade da vida exterior, perante o mundo moderno, e o ser interior, "sentidos pelo poeta conjuntamente", o que nos leva à noção de simultaneidade da expressão (ANDRADE, [1922-1925], 1980, p. 265). Essa por sua vez se completa com o material expressivo, viabilizado pelo estudo das linguagens artísticas, como a música e as artes plásticas, como também da palavra poética, ou seja, a língua portuguesa que desde $A$ Escrava que não é Isaura começa a se configurar para Mário de Andrade:

Esforçamo-nos em busca duma forma que objetive a multiplicidade interior e exterior cada vez mais acentuada pelo progresso material e na sua representação máxima em nossos dias. (ANDRADE, [1922-1925], 1980, p. 273)

Da soma de todos esses elementos chega-se ao conceito de Polifonismo, entendido por Andrade como "a união artística simultânea de duas ou mais melodias cujos efeitos passageiros de embates de sons correm para um efeito total final" (ANDRADE, [1922-1925], 1980, p. 268). Podemos assim observar que o conceito de beleza é para Mário de Andrade repensado a partir da experiência da vida cosmopolita do artista moderno, uma vez que a "simultaneidade" dos acontecimentos concorre para a "percepção artística" junto à união de todos os seus "elementos técnicos" a fim de um "efeito total final", representado pela obra artística.

O processo de criação, portanto, é visto de maneira consciente, uma vez que o poeta escolhe junto à experiência da vida e dos materiais os elementos que sintetizam e compõem a sua arte.

O poeta não fotografa: cria. Ainda mais: não reproduz: exagera, deforma, porém sintetizando. E da escolha dos valores faz nascer euritmias, relações que estavam esparsas na vida, na natureza, e que a ele, poeta, competia descobrir e aproximar. Nisto consiste seu papel de artista. (ANDRADE, [1922-1925], 1980, p. 237) 
Da experiência da mímese passa-se então à da criação, e pensando sobre isto, Andrade volta-se também à pesquisa da "língua brasileira", uma vez que o modernismo buscava o reconhecimento de uma identidade nacional e a língua é o signo capaz de estabelecer a relação e a representação entre o mundo exterior e interior de uma identidade "em construção".

Mário de Andrade passa a empregar em suas obras um português mais coloquial, que procura abranger a fala das diversas regiões do Brasil. A respeito da sistematização dessa língua, e com o intuito de diferenciar-se da língua do colonizador português, o autor de Paulicéia desvairada incita opiniões polêmicas a respeito desse projeto, como revelam algumas de suas cartas trocadas com Manuel Bandeira:

A minha naturalidade agora é a afetação porque o problema está me preocupando a todo instante e por isso me desvirtua o modo natural. Estou em época de transição. Estou criando um novo modo natural. Por enquanto se vê nisso muita afetação. Mas também não foi afetação que fez a gente policiar a sua escrita e pôr o pronome aqui porque Camões o botara aqui? Foi. Foi a afetação que fez você escrever policiadamente com o jeito de Portugal uma infinidade de escrituras suas. E eu também. $E$ toda a gente. Depois e por isso a afetação ficou geral e mudou de nome. Mais uma razão pra você: é que eu por enquanto tenho os exageros e os defeitos naturais nas revoluções e começos. (ANDRADE, [1925] 2001, p. 183)

Apesar de pretender empregar a língua falada "de Norte a Sul do país", Andrade tem consciência que esta tentativa nada mais é que uma sistematização culta da língua, uma vez que não parte de uma organização engendrada em meio ao uso popular e sim de sua elaboração e atividade como intelectual.

Não quero imaginar que o meu brasileiro - o estilo que adotei - venha a ser o brasileiro de amanhã. Não tenho esta pretensão, juro. Por outro lado se eu não fizesse essa sistematização eu seria um escritor sentimentalmente popular e quero ser um escritor culto e literário. (...) Sou um fenômeno culto, sei disso e não me afasto disso. (ANDRADE, [1925] 2001, p. 182) 
O que pretende Mário de Andrade com a sistematização da "língua brasileira"? Por um lado o autor entende seu empenho de sistematização da língua como reflexo dos momentos de "revolução", ou "começos" de um novo tempo; por outro, Andrade declara não ter a pretensão de que esta língua seja o "brasileiro de amanhã", ou seja, que alcance o uso coletivo. Do mesmo modo, se a língua não servia para representar a identidade nacional, o que depende de uma adesão social, seu uso parece estar na necessidade pessoal do autor, pois para não se tornar um escritor "sentimentalmente popular", é preciso a ele compreender a sua "própria identidade nacional". Anatol Rosenfeld aponta nestes tipos de contrastes encontrados em Mário de Andrade, o que chama de certo empenho de "boa fé", ou uma "virtude nietzschiana da verdade subjetiva", pautando a obra deste escritor sob uma curiosa teoria das "duas sinceridades". De acordo com suas palavras, "uma [dessas sinceridades] transmitindo a paisagem profunda, outra trabalhando no nível artesanal da comunicação, isto é, no espírito coletivo" ${ }^{46}$. Estas duas sinceridades correspondem ao que o crítico germânico identifica como os "dois cabotinismos" de Mário de Andrade:

(...) um feio, dos motivos profundos que impelem o artista e o homem à criação (motivos "inconfessáveis" ou "perniciosos"); e, outro, o cabotinismo da máscara, das razões oficialmente confessadas, dos "móveis aparentes", que acabam tendo igualmente influência marcante: esse cabotinismo é "nobre, necessário, maravilhosamente fecundo. A sinceridade não morre por isso. Estes móveis aparentemente insinceros, máscaras de uma realidade primeira, fazem parte da nossa sinceridade total. (ROSENFELD, 1973, p. 191-192)

Contudo Mário de Andrade nunca finalizou seu projeto denominado como Gramatiquinha da Fala Brasileira, onde visava sistematizar a fala-escrita do povo brasileiro. Um de seus livros mais fecundos neste sentido foi Macunaíma, onde utiliza a fala das diversas partes do país, como se estivesse anulando-lhe as fronteiras.

\footnotetext{
${ }^{46}$ ROSENFELD, Anatol. "Mário e o Cabotinismo". In: Texto/Contexto. São Paulo: Ed. Perspectiva, Instituto Nacional do Livro/MEC, 1973, p. 191-192.
} 
O período traçado, que vai das descobertas modernistas, através da exposição de Anita Malfatti, até 1930, seria o período tido como Cosmopolita. Dele ainda ressaltamos a figura de Lasar Segall, que imigra ao Brasil em 1923 e será uma referência constante nas análises de Mário de Andrade diante do pintor Candido Portinari.

Ao voltarmos nosso olhar à obra de José Carlos Mariátegui, procuraremos verificar como as relações estéticas estão presentes em suas análises sobre a tradição e a modernidade, e como este viés é parte fundamental de suas reflexões políticas. É interessante observarmos ainda como este autor, ao pensar nestes conceitos, desenvolve-os a partir de uma visão conjunta dos fatores sociais, e ao afirmarmos isto nos pautamos em uma de suas contribuições mais fecundas, que foi a revista Amauta. Este periódico, que pretendia representar não apenas "um movimento, mas um espírito" de uma renovação tanto vanguardista, como socialista e revolucionária, abarcou os mais diversos assuntos - políticos, filosóficos, artísticos, literários e científicos -, como também se constituiu em uma tribuna de debates que, de acordo com seu editor, não se abria a outras tendências ideológicas que não a socialista. ${ }^{47}$

Esta revista, en el campo intelectual, no representa un grupo. Representa, más bien, un movimiento, un espíritu. En el Perú se siente desde hace algún tiempo una corriente, cada día mas vigorosa y definida, de renovación. A los fautores de esta renovación se les llama vanguardistas, socialistas, revolucionarios etc. La historia no los ha bautizado definitivamente todavía. Existen entre ellos algunas discrepancias formales, algunas diferencias psicológicas. Pero por encima de lo que los diferencia, todos estos espíritus ponen lo que los aproxima y mancomuna: su voluntad de crear un Perú nuevo, dentro del mundo nuevo. (...) El movimiento - intelectual y espiritual - adquiere poco a poco organicidad. Con la aparición de "Amauta", entra en una fase de definición. (MARIÁTEGUI, 1926, nº 1)

\footnotetext{
${ }^{47}$ MARIÁTEGUI, José Carlos. Apresentação de Amauta. In: Amauta 1, (set. 1926)
} 
Diversos textos de Mariátegui apontam para suas reflexões sobre a época moderna, no entanto nos interessa, assim como em Mário de Andrade, observar como estas fornecem bases para um método de análise crítica, voltado ao modernismo cultural, como o expresso em El proceso de la literatura, contido no livro Siete Ensayos de Interpretación de la Realidad Peruana. Esta hipótese que propomos, de um método de análise crítica, fundamenta-se principalmente na postura de Mariátegui, que se autodenominava um "construtor" em relação a seu papel como intelectual.

Todo crítico, todo testigo, cumple consciente o inconscientemente, una misión. Contra lo que baratamente pueda sospecharse, mi voluntad es afirmativa, mi temperamento es de constructor, y nada me es más antitético que el bohemio puramente iconoclasta y disolvente; pero mi misión ante el pasado, parece ser la de votar en contra. No me eximo de cumplirla, ni me excuso por su parcialidad. (MARIÁTEGUI, [1928], 1958, p. 198)

A partir desta obra, e de alguns outros textos contidos em Peruanicemos al Perú e El artista y la época, tentaremos verificar a hipótese levantada em relação às abordagens do autor sobre a literatura peruana e sobre sua relação com as vanguardas européias.

A reflexão sobre o nacional será assim um fator determinante para a compreensão de como deve constituir-se a modernidade peruana. Mariátegui, ao tentar traçar uma ordenação dos períodos literários no Peru, baseia-se em uma teoria cujo princípio é idêntico, coincidentemente ou não, ao identificado na leitura realizada por Mário de Andrade na revista Europe. Segundo o autor peruano:

Una teoría moderna - literaria, no sociológica - sobre el proceso normal de la literatura de un pueblo distingue en él tres períodos: un período colonial, un período cosmopolita, un período nacional. Durante el primer período un pueblo, literariamente, no es sino una colonia, una dependencia de otro. Durante el segundo período, asimila simultáneamente elementos de diversas literaturas extranjeras. En el tercero, alcanzan una expresión bien modulada su propia personalidad y su propio sentimiento. No prevé más esta teoría de la literatura. Pero no nos hace falta, por el momento, un sistema más amplio. (MARIÁTEGUI, [1928], 1958, p. 207) 
O que nos leva a tomar esta "teoria moderna" 48 - a cuja fonte de sua leitura infelizmente não tivemos acesso - como eixo de nossa análise dos textos de Mariátegui é justamente o fato de o autor ter manifestado sua intenção de, a partir dos traços essenciais da literatura peruana, elaborar uma teoria, ou uma tese, sobre seus problemas fundamentais ${ }^{49}$. A partir da organização e da abordagem que verificamos em seus artigos contidos em Siete Ensayos de Interpretación de la Realidad Peruana, ao levantarmos as características que fornecem as bases a esta teoria, observamos que nela está contida uma metodologia pautada em seu desejo de extrair de cada autor o "extraordinário valor intrínseco da obra ou o valor histórico de sua influência" (MARITÁTEGUI, [1928], 1958, p. 304). Verificaremos assim que seu procedimento irá se fundamentar numa relação que pressupõe a personalidade do artista, no que se refere a seu posicionamento político, ideológico, "espiritual" - como se refere muitas vezes o autor - , o contexto histórico que representa, bem como os valores materiais ou formais de sua obra. A partir desses aspectos verificaremos que Mariátegui visa a formação de um "espírito" nacional que permitisse, dialeticamente, a elaboração da história de uma arte e literatura que expressassem a identidade peruana.

De acordo com Mariátegui nenhum outro método tradicional poderia ser aplicado ao caso peruano em razão do que acredita ser uma certa especificidade na constituição nacional e identitária deste povo. Para ele, a idéia do nacional não surge das concepções estéticas, mas antes de tudo, de fatores ideológicos e

\footnotetext{
48 "Por el carácter de excepción de la literatura peruana, su estudio no se acomoda a los usados esquemas de clasicismo, romanticismo y modernismo, de antiguo, medioeval y moderno, de poesía popular y literaria, etc. Y no intentaré, sistematizar este estudio conforme la clasificación marxista en literatura feudal o aristocrática, burguesa y proletaria. Para no agravar la impresión de que mi alegato está organizado según un esquema político o clasista y conformarlo más bien a un sistema de crítica e historia artística, puedo construír-lo con otro andamiaje, sin que esto implique otra cosa que un método de explicación y ordenación, y por ningún motivo una teoria que prejuzgue e inspire la interpretación de obras y autores." MARIÁTEGUI, José Carlos. Siete Ensayos de Interpretación de la realidad peruana. Lima : Amauta, 1958, p. 206-207.

49 "No he tenido en esta sumarísima revisión de valores-signos el propósito de hacer historia ni crónica. No he tenido siquiera el propósito de hacer crítica, dentro del concepto que limita la crítica al campo de la técnica literaria. Me he propuesto esbozar los lineamientos o los rasgos esenciales de nuestra literatura. He realizado un ensayo de interpretación de su espíritu; no de revisión de sus valores ni de sus episodios. Mi trabajo pretende ser una teoría o una tesis y no un análisis." Ibidem, p. 303.
} 
políticos ${ }^{50}$. De modo correlato, os elementos formais e espirituais, tanto da literatura como da vida peruana, são passadistas, e por isso refletem os resquícios de uma história colonial relacionada ao sentimento espanhol. O modernismo seria, portanto, no caso peruano, um movimento de profunda renovação social, uma vez que:

El modernismo no es sólo una cuestión de forma, sino, sobre todo, de esencia. No es modernista el que se contenta de una audacia o una arbitrariedad externas de sintaxis o de metro. Bajo el traje huachafamente nuevo, se siente intacta la vieja substancia. ?Para qué transgredir la gramática si los ingredientes espirituales de la poesía son los mismos de hace veinte o cincuenta años? (MARIATEGUI, [1924], 1970, p. 18)

Coloquemo-nos primeiramente ao lado dos textos em que o autor de El artista y la Epoca reflete sobre a literatura. Se em literatura a matéria-prima é a língua, o surgimento de uma literatura nacional só poderia existir a partir de uma língua nacional. Contudo, a escrita e a gramática quíchua, de acordo com Mariátegui, constituem obra espanhola - pois a civilização autóctone não chegou à escrita -, assim como, por outro lado, a língua castelhana representa a língua literária e intelectual do colonizador. Por isso a literatura peruana surge a partir da espanhola, não apenas devido ao idioma nela empregado, mas também porque acaba por ser concebida pelo "espírito e sentimento espanhol (MARIÁTEGUI, [1928], 1958, p. 203).

La flaqueza, la anemia, la flacidez de nuestra literatura colonial y colonialista provienen de su falta de raíces. La vida, como lo afirmaba Wilson, viene de la tierra. El arte tiene necesidad de alimentarse de la savia de una tradición, de una historia, de un pueblo. $Y$ en el Perú la literatura no ha brotado de la tradición, de la historia, del pueblo indígenas. Nació de una importación de literatura española; se nutrió luego de la imitación de la misma literatura. Un enfermo cordón umbilical la ha mantenido unida a la metrópoli. (MARIATEGUI, [1928], 1958, p.208)

\footnotetext{
50 "El florecimiento de las literaturas nacionales coincide, en la historia de Occidente, con la afirmación política de la idea nacional. Forma parte del movimiento que, a través de la Reforma y el Renacimiento, creó los factores ideológicos y espirituales de la revolución liberal y del orden capitalista. La unidad de la cultura europea, mantenida durante el Medioevo, por el latín y el Papado, se rompió a causa de la corriente nacionalista, que tuvo una de sus expresiones en la individualización nacional de las literaturas." MARIÁTEGUI, Op. cit., p. 202.
} 
À idéia de nacional associa-se a de formação de uma tradição que viesse a refletir a identidade do povo peruano. Para Mariátegui, quando se pensa em uma tradição nacional é imprescindível que se saiba distinguir entre uma "realidade profunda" e outra "superficial", uma vez que por trás de intuitos nacionalistas pode existir o mais arraigado conservadorismo ${ }^{51}$. No que diz respeito à literatura, os escritores peruanos, crioulos em sua maioria, representavam uma aristocracia que se voltava à metrópole espanhola. As civilizações indígenas eram, para esses crioulos, "estrangeiras e alheias", e por isso não se sentiam ligados a elas, como também eram "estrangeiras e alheias para os mestiços e os índios cultos, porque a educação que receberam os europeizou totalmente". Para Mariátegui, mesmo com a consolidação da República, estes literatos sentiam-se como integrantes da colônia, já que seus modelos e temas pareciam refletir uma imaginação domesticada.

\begin{abstract}
El período de nuestra historia que más nos ha atraído no ha sido nunca el período incaico. Esa edad es demasiado autóctona, demasiado nacional, demasiado indígena para emocionar a los lánguidos criollos de la República. (MARIÁTEGUI, [1924], 1970, p. 21)
\end{abstract}

A formação étnica se colocava como uma questão a ser revista. O crioulo era fruto da mistura entre o europeu e o indígena, e ainda assim misturavam-se na formação mestiça do peruano o sangue africano e asiático. No entanto, a população indígena interpunha-se quantitativamente a esta heterogeneidade, e o dualismo entre o Inca e a Colônia era uma realidade a ser resolvida não só no âmbito cultural, como econômico e político. Desde já nos interessa com tais afirmações pontuar que a relação entre a modernidade e a tradição dependia, para Mariátegui, do resgate de um "espírito indigenista", para que a literatura pudesse assim vincular-se ao povo.

\footnotetext{
51 "Podrían acusar a una mera tendencia proteccionista, dirigida a defender los productos de la inteligencia nacional de la concurrencia extranjera. Pero los adversarios de la ideología exótica sólo rechazan las importaciones contrarias al interés conservador. Las importaciones útiles a ese interés no les parecen nunca malas, cualquiera que sea su procedencia. Se trata, pues, de una simple actitud reaccionaria, disfrazada de nacionalismo. "MARIÁTEGUI, José Carlos. "Lo Nacional y lo Exótico". In: Peruanicemos al Perú. Empresa Ed. Amauta, Lima, 1970, tomo 11, p. 21.
} 
La capacidad de comprender el pasado es solidaria de la capacidad de sentir el presente y de inquietarse por el porvenir. El hombre moderno no es sólo el que más ha avanzado en la reconstrucción de lo que fue, sinto también el que más ha avanzado en la previsión de lo que será. (MARIÁTEGUI, [1924], 1970, p. 23)

Apesar da constatação de que a literatura colonial peruana existe a partir da espanhola, o autor de El Proceso de la Literatura irá apontar não apenas escritores e críticos que se filiam claramente a esta origem, mas também aborda em suas análises obras que divergem desta condição, por expressarem aspectos mais "peruanos" à literatura da época. Para isso, tomará a obra de alguns escritores e irá distingui-los dos "imitadores servis" da metrópole e aqueles "espíritos superiores", os "precursores", que trouxeram algum tipo de contribuição mais original à formação da literatura peruana ${ }^{52}$.

Um dos escritores que irá se sobressair como um "caso de exceção" da literatura colonial, aos olhos de Mariátegui, será Inca Garcilaso de la Vega (15391616), caracterizado como o primeiro "peruano", quando se tenta observar alguma "peruanidade" como formação social. No entanto, a obra de Garcilaso pertence, pelo aspecto histórico-estético, à épica espanhola.

Garcilaso, sobre todo, es una figura solitaria en la literatura de la Colonia. En Garcilaso se dan la mano dos edades, dos culuras. Pero Garcilaso es más inka que conquistador, más quéchua que español. Es, también, un caso de excepción. $Y$ en esto residen precisamente su individualidad y su grandeza. (MARIÁTEGUI, [1928], 1958, p. 204)

\footnotetext{
52 Mariátegui estará escrevendo seu testemunho em oposição à história literária pautada em escritores e críticos, como José de la Riva-Agüero (1885-1944), a quem julga não só impor suas posições políticas e sociais, como considera ainda que estas expressam uma posição acadêmica, erudita, conservadora e classista. Conforme suas palavras: "Concluída la época de incontestada autoridad "civilista", en la vida intelectual del Perú, la tabla de valores estabelecida por Riva Agüero ha pasado a revisión con todas las piezas filiares y anexas. Por mi parte, a su inconfesa parcialidad "civilista" o colonialista enfrento mi explícita parcialidad revolucionaria o socialista. No me atribuyo mesura ni eqüidad de árbitro: declaro mi pasión y mi beligerancia de opositor. Los arbitrajes, las conciliaciones se actúan en la historia, y a condición de que las partes se combatan con copioso y extremo alegato." MARIÁTEGUI, José Carlos. Siete Ensayos de Interpretacion de la Realidad Peruana, p. 201.
} 
Dentre os aspectos materiais e espirituais, Mariátegui volta-se à análise das características formais que advêm da literatura espanhola junto à colônia, como a observação sobre o gênero do discurso. Para ele, o lírico, mais subjetivo, revelaria a "infância" de toda manifestação literária, enquanto o romance, como um estágio mais avançado da narrativa épica, foi trazido pelos espanhóis através das Conquistas. Enquanto o primeiro é um tipo de expressão encontrado na literatura oral indígena, o segundo, ainda como narrativa épica, encontra na Colônia as condições necessárias para seu renascimento. ${ }^{53}$ Mariátegui, de acordo com De Sanctis, afirma então que a épica se liga aos tempos do maravilhoso, que seriam os tempos de luta, nos quais

(...) a humanidade ascende de uma idéia para outra, e o intelecto não vinga sem que a fantasia seja estremecida; quando uma idéia vingou e se desenvolve em exercício pacífico, não existe mais épica, mas a história. O poema épico, portanto, pode-se definir como a história ideal da humanidade na sua passagem de uma idéia para outra. ${ }^{54}$

Outro escritor que para Mariátegui não se vincula à imposição colonialista espanhola será Ricardo Palma (1833-1919), autor de Tradiciones Peruanas. De acordo com suas perspectivas, apesar de Palma ser eleito um representante do colonialismo, diverge de toda e qualquer exaltação da Colônia, devido principalmente ao seu estilo irônico. Esta opinião é absolutamente contrária à de Riva Agüero - autor de El carácter de la literatura en el Perú Independiente ${ }^{55}$-, a quem acusa de "deformar" a realidade peruana ${ }^{56}$, com o intuito de consolidar o

\footnotetext{
53 “(...) Y la novela caracteriza la etapa literaria que empieza con la Reforma y el Renacimiento. La novela es, en buena cuenta, la historia del individuo de la sociedad burguesa (...). La novela renacerá, sin duda, como arte realista, en la sociedad proletaria; pero, por ahora, el relato proletario, en cuanto expresión de la epopeya revolucionaria, tiene más de épica que de novela propriamente dicha. La épica medioeval, que decaía en Europa en la época de la Conquista, encontraba aquí los elementos y estímulos de un renacimiento. El conquistador podía sentir y expresar épicamente la conquista."MARIÁTEGUI, Op. cit., p. 205.

${ }_{55}$ Conf. citação de De Sanctis. Ibidem, p. 206.

55 "Riva Agüero que, en su estudio sobre el carácter de la literatura del Perú independiente, de acuerdo con los intereses de su gens y de su clase, lo coloca dentro del colonialismo, reconoce en Palma, "perteneciente a la generación que rompió con el amaneramiento de los escritores del coloniaje", a un literato "liberal e hijo de La República". Se siente a Riva Agüero íntimamente descontento del espíritu irreverente y heterodoxo de Palma." Ibidem, p. 212.

56 "Pero si se medita seriamente sobre la obra de Palma confrontándola con el proceso político y social del Perú y con la inspiración del género colonialista, se descubre lo artificioso y lo
} 
regime de uma "classe ilustrada", de origem aristocrática, descendente da metrópole espanhola. ${ }^{57}$

Don Felipe Pardo y Don José Antonio de Lavalle, conservadores convictos y confessos, evocaban la Colonia con nostalgia y con unción. Ricardo Palma en tanto, la reconstruía con un realismo burlón y una fantasía irreverente y satírica. La versión de Palma es cruda y viva. La de los prosistas y poetas de la serenata bajo los balcones del Virreinatos, tan grata a los oídos de la gente ancien régime, es devota y ditirámbica. No hay ningún parecido sustancial, ningún parentesco psicológico entre una y otra versión. (MARIÁTEGUI, [1928], 1958, p. 212)

Entre a Colônia e o Cosmopolitismo tem-se a figura de González Prada (1844-1918), autor de Páginas Libres e Horas de Lucha, referência bastante forte a Mariátegui, a quem classifica como um precursor da literatura peruana.

Este parnasiano, este helenista, marmóreo, pagano, es histórica y espiritualmente mucho más peruano que todos absolutamente todos, los rapsodistas de la literatura española anteriores y posteriores a él, en nuestro proceso literario. (MARIÁTEGUI, [1928], 1958, p. 220)

A personalidade de González Prada reúne características mais ideológicas e políticas que propriamente literárias, nas quais Mariátegui encontra os "germes de um espírito nacional". Segundo ele, Prada não interpretou o povo, mas também não desprezou o idioma das classes populares. Defendeu a ruptura da literatura peruana em relação à dependência intelectual espanhola, almejando um "espírito livre", bem como incentivou a possibilidade de contato com outras literaturas estrangeiras. Também a atitude literária é para este autor reflexo de um

convencional de esta anexión. Situar la obra de Palma dentro de la literatura colonialista es no sólo empequeñecerla sino también deformala. Las "Tradiciones" no pueden ser identificadas con una literatura de reverente y apologética exaltación de la Colonia y sus fastos, absolutamente peculiar y característica, en su tonalidad y en su espíritu, de la académica clientela de la casta feudal." MARIÁTEGUI, Op. cit., p. 212.

57 "La revisión de valores de la literatura con que debutó Riva Agüero en la política, corresponde absolutamente a los fines de una restauración. Idealiza y glorifica la Colonia, buscando en ella las raíces de la nacionalidad. Superstima la literatura colonialista exaltando enfáticamente a sus medíocres cultores. Trata desdeñosamente el romanticismo de Mariano Melgar. Reprueba a González Prada lo más válido y fecundo de su obra: su protesta." Ibidem, p. 240. 
"sentimento e interesse político", pois a literatura "não é independente das demais categorias da história".

Percibió bien su inteligencia el nexo oculto pero no ignoto que hay entre conservantismo ideológico y academicismo literario. Y combinó por eso el ataque al uno con la requisitoria contra el outro. (MARIÁTEGUI, [1928], 1958, p. 222)

Segundo ainda Mariátegui, essas idéias nem por isso configuram-se como um programa ou manifesto dentro das obras de González Prada, apesar de sua prosa estar permeada de conceitos sociológicos. Podemos dizer que, se para Mariátegui o Peru é uma nação ainda em formação, Prada, apesar de seu individualismo, reflete uma atitude literária e política necessárias para a configuração de uma nova nação.

Se debe agregar que el temperamento de González Prada era fundamentalmente literario. Si González Prada no hubiese nacido en un país urgido de reorganización y moralización políticas e sociales, en el cual no podía fructificar una obra exclusivamente artística, no lo habría tentado jamás la idea de formar um partido. (MARIÁTEGUI, [1928], 1958, p. 225)

Dentre estas várias manifestações literárias, outro fator importante a salientar dentro da crítica de José Carlos Máriátegui é a diferença por ele atribuída entre as manifestações literárias que ocorrem no campo e na cidade, mais especificamente entre as serras peruanas e a capital limenha ${ }^{58}$. Esta dicotomia se faz fundamental para compreender-se também a distância que separa a literatura de cunho indigenista, da história da literatura peruana. Uma vez que a literatura é um fenômeno urbano, fruto da Colônia e dos crioulos, as manifestações mais populares, e por isso supostamente menos cultas, são vistas com desdém pela

\footnotetext{
58 "Durante su período colonial, la literatura peruana se presenta, en sus más salientes peripecias y en sus más conspicuas figuras, como un fenómeno limeño. No importa que en su elenco estén representadas las provincias. El modelo, el estilo, la línea, han sido de la capital. Y esto se explica. La literatura es un producto urbano. La gravitación de la urbe influye fuertemente en todos los procesos literários. En el Perú, de otro lado, Lima no ha sufrido las concurrencias de otras ciudades de análogos fueros. Un centralismo extremo le ha asegurado su dominio." MARIÁTEGUI, Op. cit., p. 229-230.
} 
crítica limenha. Duas personalidades que se constituem em exceção entre esta subdivisão são Mariano Melgar e Abelardo Gamarra.

Mariano Melgar (1790 - 1815) é o primeiro intérprete da literatura indigenista no Peru. Para Mariátegui, este escritor caracteriza-se como um "espírito espontâneo" e revolucionário, pelo fato de, mesmo vivendo na capital limenha, não ser um mero imitador da literatura européia. Sua obra possui uma "sintaxe vulgar" e "expressões plebéias", expressa em fragmentos de yaravíes, que é um tipo de ritmo e poesia popular que se desenvolveu no Peru desde o período pré-colombiano. A literatura de Melgar é romântica e este estilo é encontrado tanto em sua arte como em sua atitude perante a vida.

Los que se duelen de la vulgaridad de su léxico y sus imágenes, parten de un prejuicio aristocratista y academicista. El artista que en el lenguaje del pueblo escribe un poema de perdurable emoción vale, en todas las literaturas, mil veces más que el que, en lenguaje académico, escribe una acrisolada pieza de antología. (...) la poesía popular ha precedido siempre a la poesía artística. (MARIÁTEGUI, [1928], 1958, p. 231)

Já Abelardo Gamarra (1850 - 1924) representa a mescla entre a serra e a cidade, e de acordo com Mariátegui sua obra reflete uma literatura de bases indigenistas, sendo por isso mais popular, como também mais lida. É visto como um "gênio" popular, intuitivo e espontâneo. Possuía um linguajar zombeteiro, repudiava a aristocracia encomendeira e se colocava contra o civilismo e suas expressões intelectuais e ideológicas. Era enfim um "nostálgico", de espírito "realizador" e "construtivo".

Podemos dizer que Mariátegui, ao analisar a obra de Gamarra, vincula este artista às condições e relações entre estética, ideologia e história, argumentando retoricamente acerca da falta de criatividade e de certa "modulação artística" na obra deste escritor. O artista deve ser responsável pela qualidade da obra que produz, no entanto, este artista e esta obra inserem-se num contexto mais amplo, que é o social. Assim, uma arte incipiente é fruto, muitas vezes, de um contexto igualmente responsável por este resultado incipiente, no caso, o contexto em que se insere a arte e a literatura peruanas. 
É interessante notarmos como Mariátegui caracteriza estes dois escritores, Mariano Melgar e Abelardo Gamarra, pelo espírito autenticamente peruano de suas obras, apesar de estarem mais próximos à época colonial, em que se interpõe a forte presença da cultura espanhola. Suas adjetivações, como "espontâneo" e "intuitivo", parecem aproximar a obra destes artistas a um processo mais subjetivo de produção, e portanto mais "verdadeiro" enquanto manifestação e expressão artística.

O período Cosmopolita se inicia no Peru, segundo Mariátegui, a partir do grupo Colónida, que foi um movimento de renovação surgido a partir de uma revista literária, que levava este mesmo nome, e de seu organizador Abraham Valdelomar $(1888-1919)^{59}$. Este autor, de sensibilidade cosmopolita, um "homem moderno", tem o Impressionismo como filiação mais precisa de sua arte.

Su obra es esencialmente fragmentaria y escisípara. La existencia y el trabajo del artista se resentían de indisciplina y exuberância criollas. Valdelomar reunia, elevadas a su máxima potencia, las cualidades y los defectos del mestizo costeño. Era un temperamento excesivo, que del más exasperado orgasmo creador caía en el más aiático y fatalista renunciamiento de todo deseo. Simultáneamente ocupaban su imaginación un ensayo estético, una divagación humorística, una tragedia pastoria ("Verdolaga"), una vida romanesca ("La Mariscala"). Pero poseía el don del creador. (MARIÁTEGUI, [1928], 1958, p. 251)

Colónida foi uma revista de tendência esteticista, um movimento sem contornos definidos: não possuía uma forma, não impôs um rumo estético, não constituía uma idéia ou método. É formada por um grupo de jovens, dentre eles o próprio Mariátegui, que visavam como atitude de protesto insurgir-se contra todos os valores acadêmicos. Esta revista constituiu-se em um gesto "espiritual", ao redor do qual participaram Euguren, Alberto Hidalgo, Alberto Guillen, dentre outros que, com o término desta experiência, passaram a se interessar pelas correntes políticas de influência socialista.

59 “La 'greguería' empieza con Valdelomar en nuestra literatura”. MARIÁTEGUI, op. cit., p. 251. 
Este movimento, de forte influência pradista, era também - de acordo com a visão posterior de Mariátegui - um movimento aristocrático e elitista, sem qualquer atitude ou sensibilidade política. No entanto, foi um movimento cuja atitude "espiritual" pertencia a seu tempo, que desejava a renovação dos valores coloniais e passadistas, pois não se satisfazia com o decadentismo e exotismo vigente na literatura peruana. Segundo Mariátegui, a agressividade dos Colónidas foi útil, pois cumpriram sua "função renovadora", "sacudiram a literatura nacional" e promoveram a "revisão de nossos valores literários".

Podemos verificar que junto aos escritores e obras do período cosmopolita, Mariátegui define características das quais sobressaem já um diálogo que demarca as influências advindas das vanguardas européias. De modo bastante genérico, pode-se dizer que para ele, Euguren tenderá a uma arte mais surrealista e expressionista, enquanto Alberto Hidalgo sofrerá influências do futurismo de Marinetti. No entanto, segundo suas palavras, o período cosmopolita traduz...

(...) la imitación entre otras cosas de no pocos corrosivos decadentismos occidentales y en la adopción de anárquicas modas finiseculares. (MARIÁTEGUI, [1928], 1958, p. 305)

O terceiro período, de acordo com a teoria levantada no início de nosso texto, seria o do Nacionalismo. Este período, conforme Mariátegui, assinala para a arte peruana uma nova época, a do nascimento de uma nova sensibilidade, espírito e consciência. A figura central em El proceso de la Literatura que melhor representa esta etapa será César Vallejo.

Neste poeta, nas palavras de Mariátegui, o sentimento indígena toma uma modulação própria. Nele, o dualismo entre a essência e a forma da arte - ou seja, o dualismo visto até aqui, entre o Incaico e a Colônia, bem como entre as heranças de um estilo acadêmico, conservador e uma linguagem mais autêntica e popular - deixa de existir. Sua arte não traz apenas uma "nova mensagem", como também uma "técnica e linguagem nova".

Cesar Vallejo, autor de Los Heraldos Negros e Trilce, representa o surgimento de um "gênio" criador peruano. Sua poesia aglutina tendências que estão em constante reelaboração, podendo constituir-se de elementos simbolistas, 
expressionistas, dadaístas, surrealistas. Podemos dizer que, para Mariátegui, a característica de uma técnica em constante elaboração atribuiu a Vallejo a característica de um trabalhador $^{60}$, o que de certo modo viria a caracterizar para nosso autor a idéia de um processo criativo.

Nele a linguagem enquanto expressão de uma realidade particular se "universaliza", tornando-o assim um intérprete da "humanidade"61. Mariátegui distingue-o também em relação ao seu romantismo, que de "individual" passa a um "socialismo unanimista".

Hay en Vallejo un americanismo genuino y esencial; no un americanismo descriptivo o localista. Vallejo no recurre al folklore. La palabra quechua, el giro vernáculo no se injertan artificiosamente en su lenguaje; son en él producto espontáneo, célula propia, elemento orgánico. Se podería decir que Vallejo no elige sus vocablos. Su autoctonismo no es deliberado. Vallejo no se hunde en la tradición, no se interna en la historia, para extraer de su oscuro substractum perdidas emociones. Su poesía y su lenguaje emanan de su carne y su ánima. Su mensaje está em el. El sentimiento indígena obra en su arte quizá sin que él lo sepa ni lo quiera. (MARIÁTEGUI, [1928], 1958, p. 270)

No entanto, a era do Nacionalismo, para Mariátegui, é algo em processo, pois não se concretizou totalmente no espírito peruano. Ainda em Siete Ensayos de Interpretación de la Realidad Peruana, ele nos traz como representante deste período a poetisa Magda Portal. Já nas artes plásticas, verificaremos que o artista que melhor representa este espírito nacional será o pintor José Sabogal.

Por fim, é importante ressaltarmos que tanto na crítica de Mário de Andrade, como nos escritos de José Carlos Mariátegui, verificamos que ambos

\footnotetext{
${ }^{60}$ Sobre Trilce, escreve Vallejo a Antenor Orrego: "El libro ha nacido en el mayor vacío. Soy responsable de él. Asumo toda la responsabilidad de su estética. Hoy, y más que nunca quizás, siento gravitar sobre mí, una hasta ahora desconocida obligación sacratísima, de hombre y de artista. !la de ser libre! Si no he de ser hoy libre, no lo seré jamás. Siento que gana el arco de mi frente su más imperativa fuerza de heroicidad. Me doy en la forma más libre que puedo y esta es mi mayor cosecha artística. !Dios sabe hasta donde es cierta y verdadera mi libertad! Dios sabe cuánto he sufrido para que el ritmo no traspasara esa libertad y cayera en libertinaje! Dios sabe hasta qué bordes espeluznantes me he asomado, colmado de miedo, temeroso de que todo se vaya a morir a fondo para que mi pobre ánima viva!" MARIÁTEGUI, Op. cit., p. 275.

61 "Este gran lírico, este gran subjetivo, se comporta como un intérprete del universo, de la humanidad. Nada recuerda en su poesía la queja egolátrica y narcisista del romanticismo." Ibidem., p. 273.
} 
autores procuraram compreender os processos da literatura e da arte brasileira e peruana através de suas características próprias. Podemos dizer que as fases apontadas pelo artigo do escritor norte americano, apesar de pautar-se como uma possibilidade metodológica, encontram-se, intencionalmente ou não, presentes também nas análises críticas de Andrade e Mariátegui. Este encontro se realiza, no entanto, devido ao desejo, de ambos autores, em construírem por meio de seus textos, uma consciência crítica sobre a história que partisse de referências próprias ao contexto latino-americano. Assim, verificaremos no próximo capítulo como Mário de Andrade e José Carlos Mariátegui procuraram investigar as características nacionais da produção artística de seus países. 


\section{Capítulo 3: A arte entre a teoria e a prática: Candido Portinari e José Sabogal}

Neste capítulo iremos abordar a relação entre o intelectual e o artista, partindo de suas elaborações teóricas e práticas acerca do processo de criação do objeto artístico, bem como da representatividade da obra como um elemento cultural junto à sociedade. Para pensar tais perspectivas, iremos analisar as ligações entre a crítica de arte de Mário de Andrade e de José Carlos Mariátegui das obras de Candido Portinari e José Sabogal, respectivamente. A escolha destes artistas, dentre outros que Ihes são contemporâneos, deve-se, principalmente, à "eleição" de suas obras por parte de nossos críticos, participando do que acreditamos configurar seus projetos estético-ideológicos.

Seria importante definirmos por qual perspectiva entendemos os conceitos de teoria e prática abordados. Primeiramente, entendemos a importância da teoria como aquela que não carrega a "consciência verdadeira" dos fatos do mundo, mas sim está encarregada de "conscientizar" os indivíduos perante os processos históricos e sociais. Tomamos a idéia de teoria e prática, portanto, em sentido dialético, ou seja, através de uma relação simultânea e recíproca, "por meio da qual a teoria nega a prática enquanto prática imediata", isto é, "nega a prática como um fato dado, para revelá-la em suas mediações e como práxis social", a qual podemos entender "como atividade socialmente produzida e produtora da existência social". E a prática, por sua vez, nega a teoria, enquanto "saber acabado e autônomo", que "guiaria e comandaria de fora a ação dos homens" 62.

A relação entre a modernidade e a tradição brasileira e peruana, bem como o nacionalismo como prerrogativa dos discursos elaborados por Andrade e Mariátegui, nos fazem refletir sobre as perspectivas históricas de configuração de nossas vanguardas, desenvolvidas em etapas caracterizadas, por ambos os autores, ora como heróicas, ora como decadentes ou destruidoras, e finalmente como etapa de uma arte de construção. Estas características, se tomadas como perspectivas do desenvolvimento da consciência artística, uma vez que o

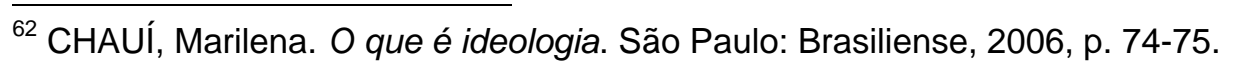


modernismo vem "libertar" a pesquisa estética dos padrões acadêmicos, tanto no Brasil como no Peru, levam-nos a indagar a assimilação e transformação dos modelos europeus para a América Latina.

Qual a relação entre as formas e conteúdos das vanguardas européias diante da assimilação por parte dos artistas brasileiros e peruanos? Se as vanguardas européias têm dentre seus intuitos romper com uma tradição pautada no excesso racionalista, qual o rompimento que buscavam as nossas vanguardas, dado que a pesquisa estética de cunho nacional se inicia nesse período? Nos libertávamos de fato dos modelos acadêmicos, por meio de expressões próprias, ou essas ainda assim denotavam a relação entre uma estética dominante e a expressão e sentimento de uma classe dominada?

O nacionalismo redimensionava o caráter identitário das sociedades brasileira e peruana, ao buscar configurar uma história cultural própria, a partir de certa "autenticidade" que distinguia os fatores internos e externos que se confrontavam na época. Esses fatores se conformarão em sentidos paradoxais, pois o nacionalismo surge no seio do movimento de uma elite que, objetivando romper com os valores de uma aristocracia tradicional, impulsiona uma revisão e equiparação de valores que acabam por questionar essa mesma classe, uma vez que os modernistas buscarão transformar o modelo culto e acadêmico, por meio da revalorização das fontes primitivas e populares.

Neste sentido, intelectuais como Mário de Andrade e José Carlos Mariátegui pautam-se em bases sociais diferenciadas, uma vez que o brasileiro seria configurado como fruto da mistura entre o branco, o negro e o índio, enquanto o peruano, para além da mistura do branco, do negro e dos coolies (descendentes asiáticos e chineses), pensava prioritariamente a partir da população indígena, que compunha a grande maioria da nação. Mas, como estabelecer a estes grupos, explorados ao longo do tempo, um valor étnico e cultural?

De modo geral podemos vislumbrar que a relação entre forma e conteúdo nas obras de Portinari e Sabogal passa por teorizações e análises contundentes por parte de Andrade e Mariátegui, os quais, ao procurarem levantar 
características que as valorizem enquanto representação plástica, fazem-nos questionar o entendimento da função do artista como representante de uma época. E, assim, questionamos também, afinal, qual o papel do crítico quanto à orientação e escolha de uma obra de arte em um determinado contexto histórico. Tal problemática nos parece importante de se formular, visto que entendemos aqui a linguagem como meio de expressão e influência social. Vale lembrar que tanto Andrade como Mariátegui "comprometeram-se" com o papel de atualização, em seus países, para a configuração de uma arte que fosse de vanguarda, em consonância com o momento internacional, sem que com isso se perdesse seu caráter nacional.

Como representantes de uma parcela intelectual da vanguarda latinoamericana, suas críticas adquirem contornos de uma escrita atuante, que objetiva analisar algumas obras e artistas que julgam relevantes; ao mesmo tempo, refletem um vanguardismo conflituoso, que na tentativa de encontrar uma produção nacional, acaba se voltando a uma arte de cunho realista, que retoma características de novas vertentes européias, como o Ressurgimento italiano e a Nova Objetividade alemã.

Este conflito poderá ser analisado por nós na crítica de Mário de Andrade e José Carlos Mariátegui, para que possamos avaliar o alcance de seus discursos na formação e construção da arte e da cultura brasileira e peruana.

\section{Candido Portinari: o pintor brasileiro}

Si é certo que ele parte da natureza para encontrar a Forma, não é menos certo que em cada forma achada ele encontra o Brasil. (ANDRADE, Mário de. Candido Portinari)

Por ocasião do Salão Nacional de Belas Artes, em 1931 - mais conhecido como Salão Revolucionário, devido à presença pela primeira vez de artistas 
modernos neste Salão ${ }^{63}$-, Mário de Andrade conhece o artista Candido Portinari (1903-1962). Em carta a Henriqueta Lisboa, em 1941, percebe-se o quanto o escritor se sente feliz por ser "o primeiro a descobrir" as pinturas de Portinari.

(...) ao passo que os modernos todos apreciavam mais outros pintores e o deixavam numa discreta penumbra, eu, nem bem cheguei, no mesmo dia da chegada, depois de um pequeno e passageiro engano com um retrato do Manuel Bandeira, estupefaciente de parecença física feito por um alemão, "descobri" colombicamente e com firmeza descobri o Portinari. Ainda não conhecia o Portinari mas logo, no meio dos sucessos obtidos pelo Cícero Dias e outros, fui afirmando sem discrepância que o bom, que o forte mesmo era o Portinari e o retrato do Borgeth o milhor quadro da exposição. (ANDRADE, [1941], 1991, p. 56-57)

O tom entusiástico de Mário de Andrade em relação à sua "descoberta", Candido Portinari, pode ser revelador não apenas por ter apontado um artista que será um dos mais comentados da época, chegando até mesmo a "monopolizar" o estatuto de melhor pintor perante os modernistas ${ }^{64}$, nem somente pelo encontro e a vivência travada como amigos. Podemos analisar esta manifestação de entusiasmo pelo viés dos intuitos estéticos e ideológicos de Mário de Andrade perante a obra do novo pintor.

Tendo em vista que até então a deformidade plástica era uma solução formal constantemente abordada por este crítico, já que, podemos dizer, expressava a subjetividade do artista através da "assimilação e deglutição" da lição estrangeira, Portinari irá combinar os requisitos dessa atitude antropofágica com uma qualidade cara à Mário de Andrade, e que até então ele vinha tentando pontuar nas obras e artistas que analisava: o conhecimento técnico entre o

\footnotetext{
${ }^{63}$ De acordo com Frederico de Moraes, o Salão Nacional de Belas Artes sempre foi um "feudo de acadêmicos". Com a direção geral de Lúcio Costa e presidida por Manuel Bandeira, a comissão organizadora da $38^{a}$ Exposição Geral decidiu convidar para participar da mostra vários modernistas de 1922 - como Di Cavalcanti, Tarsila, Anita Malfatti, além de Portinari, Guignard, Gobbis, Ismael Nery e Cícero Dias -, bem como aceitar todos os inscritos. Ao ser inaugurando o Salão Revolucionário, houve pressão, os alunos da ENBA entraram em greve e Lúcio Costa foi demitido. In: MORAIS, Frederico. Panorama das Artes Plásticas, Séculos XIX e XX. $2^{\mathrm{a}}$ ed. rev. São Paulo: Instituto Itaú Cultural, 1991, p. 131.

64 Conf. Paulo Mendes de Almeida aponta nas relações entre o "portinarismo" e o "antiportinarismo". In: De Anita ao Museu. Paulo Mendes de Almeida. São Paulo: Editora Perspectiva, 1976.
} 
"clássico-moderno". De acordo com Annateresa Fabris, Portinari transforma-se no "representante dos ideais modernistas", pois:

O antigo aluno da Escola Nacional de Belas Artes que, na Europa, descobrira o moderno e o verdadeiro significado da tradição, sabia desenhar conforme ditames do figurino acadêmico. Argumento validíssimo para opor aos detratores do moderno: que melhor exemplo para negar o desconhecimento das regras do desenho por parte da nova geração? Se os passadistas faziam uma equação do tipo deformação modernista = ignorância do métier, Portinari permitia demonstrar que a deformação, tão criticada pelos defensores da tradição cega, representava, na realidade, a busca duma nova expressão artística. (FABRIS, 1990, p.27)

Assim como grande parte dos artistas de sua geração, Candido Portinari viaja para a Europa em 1928 - através de um prêmio adquirido, neste mesmo ano, com o retrato Olegário Mariano -, onde permanece até 1930. Antes dessa viagem, porém, o percurso de Portinari com o fazer artístico já se manifestava desde criança. Natural de Brodósqui, interior de São Paulo, muda-se em 1918, aos 15 anos, para o Rio de Janeiro a fim de estudar pintura, quando ingressa, em 1921, na Escola Nacional de Belas-Artes. Tem como professores Rodolfo Amoedo e Batista da Costa, bem como é influenciado pelo pintor espanhol Ignacio Zuloaga (1870-1945), cuja obra "foge do tratamento romantizado, típico da expressão acadêmica, caracterizando-se por um desenho simples e por sombras duras e acentuadas"65. Ao viajar para a Europa, Portinari conhece a Inglaterra, Itália, Espanha e França, permanecendo neste último país por mais tempo. É com a experiência internacional que descobre a arte do Renascimento italiano e a pintura da Escola de Paris. Somente quando retorna ao Brasil, em 1931, é que entra em contato com o grupo modernista brasileiro ${ }^{66}$, que por esta época começava a manifestar interesses pela problemática sociopolítica.

\footnotetext{
${ }^{65}$ Apesar de nosso estudo não possuir a intenção de comparar as obras de Candido Portinari às de José Sabogal, vale pontuar que algumas das influências iniciais desses artistas coincidem, como por exemplo, a do pintor espanhol Ignacio Zuloaga. A citação sobre o artista espanhol foi extraída do livro de Annateresa Fabris, Portinari, o pintor social, p. 10.

${ }^{66}$ FABRIS, Annateresa. Portinari, pintor social. São Paulo: Perspectiva: Editora da Universidade de São Paulo, 1990, p. 06.
} 
As questões formais na crítica de Mário de Andrade a partir do "advento Portinari" parecem tornar as "necessidades das leis estéticas", levantadas em $A$ Escrava que não é Isaura, o quesito fundamental para que se possa alcançar uma "verdadeira expressão artística". Seria este momento em que o crítico chega à idéia de que o conhecimento formal e a importância do conteúdo em arte possuem a mesma importância, uma vez que ambos podem significar a mesma coisa? Ou o conteúdo passa a ser, a partir desse período, a preocupação maior na crítica de Mário de Andrade? Se o conteúdo torna-se mais importante, pode-se afirmar que há uma mudança quanto aos rumos e intuitos modernistas. Tendo em vista a importância do conhecimento da tradição, apontado em Portinari, estaria então o modernismo valorizando formas "mais acadêmicas" da arte? Qual a relação então entre forma e conteúdo como expressão de modernidade para a arte brasileira?

Aqui podemos adentrar na terceira fase apontada no capítulo anterior sobre o nacionalismo como dado característico da modernidade americana e analisarmos quais deveriam ser os valores estéticos e ideológicos que o compõe.

Para avaliarmos as relações entre forma e conteúdo na arte como possuindo ou não o mesmo significado e valor, podemos nos pautar no que Antonio Cândido denomina como "redução estrutural". Segundo este crítico, o que interessa não é tanto a relação do texto, ou se assim pudermos distender, da obra de arte, com a sociedade, e sim a transformação da sociedade em texto ou obra.

O escritor toma os dados da realidade, submete-os à fantasia e produz algo que, apesar de muito parecido com a realidade, é outra coisa. (...). Fazendo uma comparação primária, me interessa averiguar de que maneira o autor mói a realidade, que sai transformada, assim como a carne do boi é posta na máquina de moer e acaba croquete. Croquete não é boi, é uma coisa nova, que obviamente provém da realidade, mas difere dela. Na realidade não existe o croquete, existe a carne do boi" 67 .

Se observarmos os quadros de Portinari, O Violinista Retrato de Oscar Borgeth (1931), e o Retrato de Manuel Bandeira (1931), apresentados no Salão

${ }^{67}$ Entrevista com Antonio Candido. In: A Tradição Esquecida: os parceiros do Rio Bonito e a sociologia de Antonio Candido. Luiz Carlos Jackson. Belo Horizonte: Ed. UFMG; São Paulo: FAPESP, 2002, p. 170. 
Revolucionário de 1931, podemos verificar que tanto num como no outro, o artista parece se valer de formas clássicas de composição, tendo em vista as estruturas das pinturas, traçadas a partir de uma perspectiva central, cuja regularidade geométrica e harmonia cromática conferem certo equilíbrio à obra. Apesar desses retratos se diferirem consideravelmente em relação aos tons, as cores e a luminosidade contudo, parecem "desenhar" as imagens, tornando as composições construídas como que a partir de termos cromáticos ${ }^{68}$. Essas cores e luzes, aliadas a cada um dos retratados, configuram tanto os elementos "externos" ou estruturais - como o espaço onde se encontram as figuras e a relação entre primeiro, segundo e demais planos das obras -, como parecem ainda conotar a interioridade dos modelos, atribuindo-Ihes certa subjetividade psicológica. No retrato de Oscar Borgeth, conforme aponta Annateresa Fabris, "o jogo de brancos, cinzas e marrons é realçado por um fundo neutro, feito de manchas azuis e marrons, que permite concentrar toda a luminosidade na figura do violinista"69. Apesar deste contraste entre as cores, o caráter "ensimesmado" de Borgeth parece coincidir com a densidade das cores escuras e a nebulosidade do plano de fundo, como se nelas pudéssemos ter a sensação do que se passa no "interior" do retratado. No Retrato de Manuel Bandeira, os "tons atenuados" e a "luminosidade difusa" parecem "unificar os dois registros da tela"70. Assim se a figura do escritor parece se impor a nós no primeiro plano da tela, ao mesmo tempo, a paisagem do Rio de Janeiro, que Ihe faz fundo, não nos parece apenas um segundo elemento que compõe o espaço. As cores entre um e outro se harmonizam a tal ponto que parecem "fundir" uma imagem na outra, tornando o homem e a natureza de certo modo interligados. Também a luminosidade atribuída a ambos os planos, tanto na imagem do poeta, como no infinito da paisagem, nos traz uma sutil sensação de igualdade entre a beleza da paisagem "externa" (representada

\footnotetext{
${ }^{68}$ Alguns desses elementos, bem como uma leitura contrastiva bastante contundente entre estas obras e a do artista alemão Friederich Maron (1887-1944), também apresentada nesta exposição, foi feita por Annateresa Fabris no livro "Portinari, amico mio: cartas de Mário de Andrade a Candido Portinari", p. 13-17.

${ }^{69}$ Ibidem, p. 16.

${ }^{70}$ Ibidem, p. 16.
} 
pelo infinito do céu e do mar carioca) e a "beleza interna" do escritor brasileiro (podendo ser relacionada ao vasto conhecimento poético de Bandeira).

A relação entre o conhecimento dos elementos técnicos e os elementos psicológicos, será analisada por Mário de Andrade tanto sob a perspectiva da obra, como do ponto de vista do domínio e conhecimento técnico do artista. Em carta a Manuel Bandeira, Andrade faz um contraste entre a obra de Portinari e a do pintor alemão Friedrich Maron (1887-1944), a partir do conhecimento técnico dos dois artistas no que se refere ao uso que fazem da tradição artística. Segundo Andrade, Maron, ao tomar como referência as paisagens do pintor espanhol Ignácio Zuloaga, não as compreende. O pintor espanhol retratava figuras junto a paisagens que nada tinham a ver uma com as outras, no entanto, as questões estruturais eram bem definidas. Essas paisagens diferem-se das de Maron - cuja pintura apresentada no Salão de 1931, também retratava Manuel Bandeira frente a uma paisagem do Rio de Janeiro -, pois apesar do crítico considerar as obras de Zuloaga ruins, este porém:

(...) não errava totalmente como problema de quadro, porque sendo técnico excelente, jamais permitiu que a paisagem sobrelevasse sobre o retrato. (...) $E$ às vezes admiravelmente concertantes, em que a paisagem vira interpretativa ou complementar da figura, ou da técnica do pintor, como é nos quadros de Guignard. Ora Maron, servindo-se da composição tradicional desatendeu completamente aos problemas dela. Em vez de dois temas musicais concertantes, o quadro dele tem dois assuntos. (ANDRADE, [1931], 2001, p. 524-525)

Como podemos entender o uso do conhecimento da tradição exigido por Mário de Andrade, uma vez que a proposta das vanguardas européias, às quais os modernistas brasileiros "se filiaram", pretendiam romper totalmente com o uso dos elementos tradicionais da composição artística?

Em 1934, num artigo escrito para o Diário de São Paulo, verificamos que algumas das possíveis respostas a essa questão são abordadas na crítica de Mário de Andrade. O texto traz implícito um contrapondo entre a personalidade do artista Portinari em relação ao contexto dos artistas brasileiros. Podemos depreender esta afirmação a partir de algumas adjetivações generalizadas, mas 
repletas de significados, que o crítico utiliza pra qualificar os processos de criação artística no Brasil. Ao se referir à Portinari, qualifica-o a partir de sua "honestidade artística", o que julga excepcional para o contexto do país. Segundo suas palavras, Portinari era:

(...) estudioso dos problemas da pintura, ele não é porém nunca o artista "viajante" que, possuidor de habilidades inatas e observação boa, se diverte repetindo estilos, concepções estéticas e técnicas diversas. Pelo contrário, imprime uma tal força de verdade, de seriedade às obras dele, que se tem a impressão de que o artista não se diverte nunca. (ANDRADE, 1934, Diário de São Paulo)

A referência à idéia de artista "viajante", que possui "habilidades inatas" e "observação boa", e que se "diverte repetindo estilos, concepções estéticas e técnicas diversas" parece ser como Andrade avalia uma parte da produção artística brasileira que, do seu ponto de vista, era representada por artistas que viajavam ao estrangeiro e dessa experiência retornavam "repetindo" os padrões estéticos que lá se desenvolviam, sem qualquer reflexão ou solução estética mais aprofundada quanto às necessidades e diferenças do contexto histórico-social e artístico brasileiro.

Para Andrade, a heterogeneidade que se apresentava nas obras de Portinari ligavam-se ao drama do artista e do homem contemporâneo, pois este "não quer abandonar os direitos desinteressados da arte pura, nem as intenções interessadas do homem social" ${ }^{71}$. Portinari é analisado pelo crítico como um virtuose $^{72}$, cujo domínio técnico é capaz de "dispersar" os valores sociais tratados nos quadros, ou seja, cujas formas empregadas contêm em si os valores e tradições artísticas. Assim a virtuosidade do artista é tomada, de acordo com o crítico, também em seus valores expressivos. Se, por um lado, Portinari se torna um "antimoderno", por outro, "não está brincando de aplicar elementos alheios ou tradicionais". Suas pinturas são impregnadas de "vibração e sensibilidade", atribuindo à obra, o que poderíamos dizer, uma solução individual do artista, o que

\footnotetext{
${ }_{71}^{71}$ ANDRADE, Mário de. Portinari. In: "Diário de São Paulo", São Paulo, 15 dez. 1934.

72 Sobre este tema consultar também CHIARELLI, Domingos Tadeu. Pintura não é só beleza: a crítica de arte de Mário de Andrade. Florianópolis: Letras Contemporâneas, 2007, p. 128-131.
} 
para o crítico, será um dado relevante enquanto característica da contradição existente na obra do pintor brasileiro entre o clássico e o moderno...

A pastosidade forte, a expressão conceptiva de Futebol recorda Breughel. Isso importa nada. Portinari, quando emprega esses elementos, não apenas os torna próprios dele como os torna próprios do quadro, de tal quadro determinado. São imprescindíveis ali. Daí a força de convicção e a imprescindibilidade com que ele chega a aplicar um fundo de quadro alheio a uma figura integralmente dele (...). (ANDRADE, 1934, Diário de São Paulo)

A mesma relação - a da solução individual do artista perante o saber clássico e moderno - também pode ser compreendida no texto de Mário de Andrade através da comparação traçada entre a obra de Candido Portinari e Pablo Picasso (1881-1973). A heterogeneidade das obras de Picasso é vista como o desejo deste "artista e homem contemporâneo", de procurar novas soluções que ainda "estão por se justificar", enquanto em Portinari a heterogeneidade advém da tradição, pois "são forças já adquiridas que ele põe ao serviço duma realidade que só poderia ser aquela". A obra de Picasso "vem de seu futuro", é "de preferência uma lição, um convite". A de Portinari, "vem do seu passado", "é essencialmente uma lição". A do espanhol "abre portas", a do brasileiro "fecha portas", e ainda, "dá a sensação calma do círculo. Completo e decisivo"73.

Nas obras de Portinari, como em o Sorveteiro (1934), Andrade aponta que se pode encontrar nos pés da mulata na tela representada, elementos como "as elefantíases das figuras de Picasso". O crítico não apenas alude ao alcance das referências de Portinari, que não estão restritas apenas à influência da arte de vanguarda européia, como busca também suas fontes em modelos e orientações mais antigas como, no caso dessa pintura, na estátua da Venus de Milo. Em o Sorveteiro, Andrade nos chama ainda a atenção sobre a "aplicação minunciosamente calculada das perspectivas, a disposição das massas, a distribuição dos tons quentes, frios e neutros" e por fim, a "salientação voluntariosa dos volumes". Podemos perceber que o crítico apóia-se basicamente nos valores

\footnotetext{
${ }^{73}$ ANDRADE, Mário de. Portinari. In: “Diário de São Paulo”, São Paulo, 15 dez. 1934.
} 
formais da obra, apesar de o assunto nela representado nos parecer bastante significativo. A cena nos reporta a um cotidiano simples, podemos dizer que até mesmo de uma situação interiorana, em que um sorveteiro passa na rua, em direção a duas mulheres e uma criança. Essa cena prosaica é ao mesmo tempo ressaltada tanto pela referência a que as figuras nos remetem, sobre o caráter identitário desses personagens, representados por negros, como também pelo valor escultórico dado a seus corpos. Dessa maneira, podemos dizer que a obra não se distingue apenas pelo que Mário de Andrade nos aponta, que é sua qualidade técnica, mas também pelo assunto que é capaz de nos remeter ao imaginário de um contexto tipicamente brasileiro. Apesar das obras posteriores de Portinari possuírem referências bastante diretas aos experimentos cubistas de Picasso, como por exemplo no quadro Os Retirantes (1944), é importante analisarmos as tentativas do crítico de diferenciar um e outro artista quanto aos valores que regem suas obras. Mas porque Andrade aponta primordialmente os valores formais da obra?

Podemos entender que Picasso "é de preferência uma lição", é aquele que "abre portas", devido principalmente ao conhecimento técnico e à consciência do contexto histórico-social e artístico europeu que o pintor possui. Mediante tal conhecimento é que o artista espanhol é capaz de perceber, por exemplo, o potencial das formas e valores implícitos nas esculturas negras, perante ao marco, para ele, das soluções plásticas alcançadas por Cézanne (1839 - 1906). A partir destas relações é que Picasso "abre portas", por exemplo, para as novas possibilidades de estudo das estruturas plásticas, que iria excluir as distinções entre forma e espaço na obra de arte, características estas que culminarão no Cubismo $^{74}$.

Portinari, por outro lado, "é essencialmente uma lição", é aquele que "fecha portas" pois demonstra com suas obras que antes de alguém romper com as formas mais clássicas e acadêmicas da arte, como fizeram os modernistas de 1922, é necessário reconhecê-las como inscritas em uma tradição, para só então

\footnotetext{
${ }^{74}$ Para a análise das concepções estruturais da obra de Picasso nos pautamos nas observações de Giulio Carlo Argan sobre a obra Les demoiselles d'Avignon (1907). In: Arte Moderna. Giulio Carlo Argan. São Paulo: Companhia das Letras, 1992, p. 422-426.
} 
"destruí-las". Por isso as obras do pintor brasileiro podem ser comparadas a um "círculo", "completo e decisivo", conforme as palavras empregadas por Mário de Andrade, pois suas obras engendram o processo do fazer artístico, através de valores técnicos e expressivos, perante o contexto histórico-social e artístico não apenas local, mas de caráter universal.

A relação entre a adaptação das influências e experiências das vanguardas européias junto ao contexto brasileiro será uma preocupação constantemente debatida entre Mário de Andrade e alguns artistas que vinham "aderindo" às novas tendências cubistas, futuristas, surrealistas, dentre outras. Em uma carta de 1923, dirigida à pintora Tarsila do Amaral quando esta encontrava-se em Paris, Andrade diz: “(...) Creio que não cairás no cubismo. Aproveita deste apenas os ensinamentos. Equilíbrio, Construção, Sobriedade. Cuidado com o abstrato. A pintura tem campo próprio (...)" ${ }^{\prime 75}$. Já em outra carta de 1927, dirigida à Prudente de Moraes, neto, Mário de Andrade assim define sua postura perante o surrealismo:

(...) Considero o sobrerrealismo a conseqüência lógica e a quintessência de arte dum país que nem a França. No Brasil acho que no momento atual, pros que estão de deveras acomodados dentro da nossa realidade, ele não adianta nada. Não adianta porquê não ajuda. Todas as questões que são de vida ou de morte prá organização definitiva da realidade brasileira (coisa que indiscutivelmente está se dando agora) nos levam pra uma arte de caráter interessado que como todas as artes de fixação nacional só pode ser essencialmente religiosa (no sentido mais largo da palavra: fé pra união nacional, psicologia familiar social religiosa sexual). E creio que você sabe os sacrifícios enormes de mim que fiz nesse sentido. Eu, Prudentico, sou um indivíduo desabusado e feliz, com uma autocrítica severa que jamais não me permitiu achar um bom valor artístico numa obra minha e que só justifico a publicação das obras que faço porque elas são obrasações. Em vez de pregar, faço. (...) São por essas razões extra-estéticas que eu não posso me abandonar quando vejo uma força ao mesmo tempo tradicional e moderna (...). Repare também que não articulo aqui nenhum

${ }^{75}$ Carta de Mário de Andrade a Tarsila do Amaral, em 16 de junho de 1923. In: Amaral. Aracy. Tarsila, sua obra e seu tempo. Alguns desses trechos sobre o que Mário de Andrade compreendia pelas vanguardas históricas encontram-se citados também na ampla pesquisa realizada por Domingos Tadeu Chiarelli. In: Pintura não é só Beleza: a critica de Arte de Mário de Andrade. 
(sic) contradição de valor estético contra o sobrerrealismo. Tenho várias. Porém elas não importam agora. O que me importa é não ver você marcar passo nem se manifestar seguindo uma fadiga (considero o sobrerrealismo um fenômeno (sic) de fadiga aliás perfeitamente psicológico e natural na França) (...). (ANDRADE, [1927], 1985, p. 248-249)

A partir dessas citações podemos verificar que as análises de Mário de Andrade em relação às teorias e às práticas artísticas devem ser diferenciadas de acordo com o contexto histórico-social. A França, de acordo com suas palavras, é um país "fatigado", onde o surrealismo é engendrado perante um contexto social situado no entre guerras. No Brasil, cuja formação artística até então advinha basicamente da influência francesa, o surrealismo foi necessário enquanto impulso lírico, como expresso desde Paulicéia Desvairada, para a criação de formas mais livres da arte que a partir do inconsciente manifestasse formas próprias de expressão.

A diferença entre as "teorias e práticas" investigadas por Mário de Andrade em relação às vanguardas históricas podem ser aqui refletidas, em termos de construção de uma contra-ideologia ${ }^{76}$ aos valores, às idéias e às práticas artísticas européias, uma vez que a valorização da manifestação do inconsciente na arte, e de um modelo de vida mais espontâneo e "primitivo", sob a perspectiva européia, é diferente da valorização do primitivo, sob a perspectiva latinoamericana. Mário de Andrade, a par de teorias e análises históricas, interpretadas no período entre guerras freqüentemente sob pontos de vistas raciais e biológicos, contrapõe-se a algumas dessas interpretações, como podemos encontrar em suas anotações marginais, traçadas no livro El tema de nuestro tiempo (1923), do filósofo espanhol José Ortega y Gasset.

Ortega y Gasset entende que a história não é regida por princípios que a regulem, e por isso a compreende como fruto de uma ação humana espontaneísta e vitalista. Por conseguinte, analisa a modernidade artística não apenas como um

\footnotetext{
${ }^{76}$ De acordo com Marilena Chauí, podemos entender o conceito de ideologia como sendo um "sistema abstrato de representações, normas, valores e crenças domintantes que invertem a realidade, produzindo uma universalidade e uma unidade ilusórias, que ocultam a divisão social de classes". CHAUÍ, Marilena. Cidadania e Cultural. 1. Ed. São Paulo: Ed. Fundação Perseu Abramo, 2006, p. 21.
} 
fenômeno cultural, mas como um ato de fruição individual e biológica, chegando à conclusão de que a fruição de um quadro primitivo equivale à que obtemos a partir da contemplação da alma infantil. De acordo com esse autor, "la gracia del candor es, pues, la delectación del fuerte en la flaqueza del débil"77. Perante estas palavras, vale a pena transcrevermos as anotações de Mário de Andrade, sob elas escritas e que as rebatem como "complemento errado":

A gente gosta do primitivo no que ele tem de primitivo e não pelo que nós não temos de primitivo. O que a gente gosta no primitivo é que ele é síntese, é realismo, é deformação e símbolo. Na arte do primitivo tem abandono das particularidades analíticas e tem revivescência sistemática dos valores essenciais, religião, beleza, política, verdade, bondade, amor, etc.etc...

No seu realismo sintético ele abandona as cambiantes e atinge valores plásticos e sonoros legítimos e reais. É o realismo dele. $\mathrm{Na}$ sua deformação sintética atinge mais fortemente a expressão, que nem nas deformações de soldados romanos do Aleijadinho nos Passos de Congonhas. E por essa mesma deformação atinge uma simbologia eminentemente metafórica e lírica. Por tudo isso o primitivo (que em geral é um ser que cria interessadamente) é muitas vezes mais puramente artista que um artista não primitivo. E é essa arte que gostamos. (ANDRADE, 1923, p. 65) $^{78}$

Conforme nos aponta Telê Porto Ancona Lopez, Andrade, ainda nessa primeira fase, entendia que o moderno deveria ser "o primitivo de uma nova era", pelo abandono da perfeição acadêmica e a adesão a experimentações e criações ousadas. Assim o autor propõe uma renovação da linguagem que estaria, de acordo com a autora, simultaneamente ligada ao realismo e à estilização ${ }^{79}$.

77 ORTEGA Y GASSET, José. "El tema de nuestro tiempo. El ocaso de las revolucione. El sentido histórico de la teoría de Einstein". Apud ANTELO, Raul. In: Na Ilha de Marapatá: Mário de Andrade lê os hispano-americanos. São Paulo: HUCITEC; [Brasília]: INL, Fundação Nacional Pró-Memória, 1986, p. 96.

${ }^{78}$ Mário de Andrade subdivide a leitura que faz nesta obra a partir dos seguintes tópicos por ele anotados: "política, gerações, ceticismo, vida humana, trabalho, arte nova, esporte, modernismo, primitivismo, revolução, pensamento". Anotações marginais de Mário de Andrade. In: El tema de nuestro tiempo. El ocaso de las revoluciones. El sentido histórico de la teoría de Einstein. Madrid : Calpe, 1923, p. 154. Também citado por: ANTELO, Raul., Op. cit., p. 96-97.

${ }^{79}$ LOPEZ, Telê Porto Ancona. Op. Cit., p. 232. 
Realismo é a realização dos elementos despertados ao toque da sensibilidade recriadora que penetra até o inconsciente. Estilização,é a ação consciente e crítica de deformação e síntese. (LOPEZ, 1972, p. 232)

Tendo em vista o percurso traçado, podemos observar que,por um lado, na tentativa de desvincular a criação artística do "modelo dominante" representado pelo europeu, o crítico, no início de suas formulações, entendia a arte "primitiva" como uma verdadeira manifestação artística, por comportar o que ela tem de primitivo, ou seja, "o abandono das possibilidades analíticas", a "revivescência dos valores essenciais" através da simbologia, originados a partir de uma criação "interessada" na vida. Por outro lado, Andrade procura encontrar no conhecimento técnico e na virtuosidade de Portinari elementos que julgava essenciais na formação de um "verdadeiro" artista. Perante tais afirmações, podemos indagar o que muda propriamente na crítica do escritor, entre uma época e outra, diante de conceitos e definições estéticas tão distintas, como o entendimento sobre realismo, advindo da idéia da recriação e deformação primitiva, e o desejo de uma arte que fosse clássico-moderna, como a que encontrou na obra de Candido Portinari. Podemos tentar responder a esta questão através da idéia de obra de "arte interessada", na qual Mário de Andrade via a possibilidade de ligar as camadas mais intelectuais ao povo, no intuito de contribuir para a criação de uma cultura nacional ${ }^{80}$.

Ainda ao texto publicado no Diário de São Paulo, de 1934, Mário de Andrade, já apontava o que acreditava ser, além da virtuosidade, uma questão diferencial na obra de Portinari, e que pode ser vista como um "convite", assim como as obras de Picasso: a "técnica das pinceladas quase esculturais, que dão uma sensação de afrescos". Obras como o Sorveteiro, Mestiço, Preto da enxada, Café, como também alguns retratos do pintor, possuem uma lógica tão rija, de

\footnotetext{
80 "A arte tem de servir. Venho dizendo isso há muitos anos. É certo que tenho cometido muitos erros na minha vida. Mas com a minha arte interessada, eu sei que não errei. Sempre considerei o problema máximo dos intelectuais brasileiros a procura de um instrumento de trabalho que os aproximasse do povo. Esta noção proletária da arte, da qual nunca me afastei, foi que me levou, desde o início, às pesquisas de uma maneira de exprimir-me em brasileiro." Entrevista de Mário de Andrade concedida à Diretrizes, 1944. In: Entrevistas e depoimentos. Mário de Andrade. Org. Telê Porto Ancona Lopez. Ed. II. São Paulo: T. A. Queiroz, 1983, p. 105.
} 
acordo com Andrade, que atribui ao quadro certo aspecto "monumental", de "força escultórica". Essa passagem da pintura de cavalete à pintura de painéis e afrescos será um diferencial na obra de Portinari - em relação à toda sua produção de até então - bastante exaltada por Mário de Andrade, devido principalmente ao caráter de coletividade que esse tipo de meio pressupõe, e da compreensão do "homem da rua" que exige do artista ${ }^{81}$. Portinari deixa assim de ser um "pintor de elites pequenas", cuja pintura possui um caráter erudito, e passa através de seus murais, a ser um artista das massas e "dos em geral". O artista era visto conforme as palavras de Andrade como: "um legítimo virtuose na ciência de utilizar os processos anti-realistas da composição e da deformação"82, e, no entanto, tornase com a pintura mural, um realista.

Portinari se faz realista. As fotografias expostas neste número da Revista Acadêmcia provam bem esse realismo e de que espécie ele é. Uma espécie de realismo moral, franco, forte, sadio, de um otimismo dominador. Nisto ele se separa radicalmente da obra amarga e rancorosa de um Rivera. (ANDRADE, Revista Acadêmica, 1938)

Podemos perceber que Andrade opera sob dois conceitos de realismo, o primeiro, alcançado através da "virtuosidade" e dos "processos anti-realistas de composição", poderíamos compreendê-lo como algo relacionado aos valores "clássicos" que compõem a obra. O segundo, seria aquele pautado num realismo "moral, franco, forte, sadio, de um otimismo dominador", que assim como o realismo que define na arte primitiva, é aquele engendrado na "realidade" para dela extrair valores simbólicos. Em referência aos afrescos do Ministério da Educação e Saúde Pública, no Rio de Janeiro, que Portinari realizou a convite do Ministro da Educação Gustavo Capanema, Andrade assim definiu o processo artístico de Portinari:

\footnotetext{
${ }^{81}$ ANDRADE, Mário de. "Portinari”. In: Bellas Artes. São Paulo: out. 1938, p. 03.

${ }^{82}$ Artista inquieto e insatisfeito, essencialmente moderno, muito mais pela sua característica de experimentador infatigável como um Picasso e um Strawinski, legítimo virtuose na ciência de utilizar os processos anti-realistas da composição e da deformação, Portinari atingiu a pintura de parede despindo-se de todos os seus processos de pintor de cavalete. Com uma segurança, com uma humildade extraordinária. A bem dizer: os afrescos atuais não se ligam a nenhuma das numerosas fases porque já passou a pintura do artista. Portinari sempre foi um pintor para as elites pequenas. ANDRADE, Mario de. Revista Acadêmica. nº 35, maio, 1938.
} 
Para os afrescos do Ministério, todas as figuras foram separadamente estudadas com verdadeira minucia anatômica. Depois desses estudos longos, e que formam às vezes coleções esplendidas de desenhos perfeitamente clássicos, Portinari como que faz taboa raza de tudo quanto desenhou e compôs. Liberta-se de tudo e pinta livremente, sem se preocupar de perspectivas, sombras e realidades anatômicas. Às vezes, um detalhe de inspiração primeira, rápido, impressionista, ele o reproduz minuciosamente, conservando-Ihe toda a rápida espontaneidade. Ora obedece, ora desobedece à perspectiva ou ao sistema das sombras. Pinta livremente enfim. (ANDRADE, O Estado de São Paulo, 1939)

A partir da definição e compreensão de como Mário de Andrade do realismo de Candido Portinari, podemos então tentar entender por que nosso autor difere do realismo presente nos murais do artista mexicano Diego Rivera (1886 - 1957). Para Andrade:

Rivera é um combatente. Portinari é um missionário. Rivera é um expoente da turbulência política dos nossos dias. Portinari é um educador. A desigualdade, o tumulto, a gritaria mais propriamente literária que plástica, de Rivera, deriva de sua própria psicologia. Portinari, sob o signo dos antigos em que se colocou, ao mesmo tempo que pode conservar uma calma, um equilíbrio, uma temática que nada tem de libertários, e são exclusivamente plásticos, soube dar uma esperança ao mundo. (ANDRADE, Revista Acadêmica, 1938)

Compreendemos que esta diferença se estabelece para o crítico através da função que a arte deve ter perante a sociedade. A definição de Rivera como um artista político, enquanto Portinari seria um artista educador ${ }^{83}$, nos parece um argumento que tenta estabelecer o valor da arte em relação à sua época, não no que esta possui de "pregação política" - se assim pudermos entender a "gritaria" "literária" a que Andrade se refere -, mas através do que esta possui de

83 Uma contraposição sobre esta opinião está em José Carlos Mariátegui, para quem Diego Rivera é o artista que melhor realiza este encontro entre arte e política: “(...) sú obra sólo empieza a ser personal cuando la revolucion comienza a inspirarla plenamente. (...) El grande artista conoció todas las escuelas y estúdio todas las corrientes de su época. Ninguna encendió sus potencias creadoras, ninguna sacudió su subconciencia artística como los rudos episódios de la insurección agrarista. MARIÁTEGUI, José Carlos. Intinerario de Diego Rivera. In: El artista y la época. Lima: Editora Amauta, 1990, p.94. 
revolucionário a partir de sua própria linguagem. Mário de Andrade compreende as obras de Candido Portinari como profundamente brasileiras, não apenas pelos "costumes", "ar", "cheiro", "clima deste painéis", mas também pela tradição, expressa pela técnica e assuntos abordados, de verdadeiro sentimento nacional ${ }^{84}$.

Para compreendermos os valores implícitos a esta perspectiva, a das características que deveria ter um artista nacional, seria interessante analisarmos o artigo escrito por Mário de Andrade, em 1939, intitulado Candido Portinari, no qual the atribui como valor primordial uma profunda "unidade plástica". Esta característica, que segundo suas palavras poderia parecer "inexpressiva e redundante" quando atribuídas a uma pintura, deve ser ressaltada, principalmente quando ocorrem em períodos de academização, em que os princípios fundamentais da arte, que seriam o de realizar a sua própria natureza, são pouco explorados.

Quais caminhos deveriam então percorrer a arte frente ao que Mário de Andrade qualifica de "períodos inquietos de pesquisa estética"? Haveria uma forma ou assunto ideal que imbuísse a arte de certas "qualidades essenciais"? Quais seriam essas qualidades? E o papel do artista frente às exigências deste intuito?

Partindo das observações que Andrade irá valorizar em Portinari, podemos ressaltar os valores que nosso crítico julgava fundamentais para a sua idéia de artista: a conjugação entre a técnica e a expressão. Em seu entender, quando se pensa em conhecimento técnico, deve-se somar à figura do artista, o artesão, pois é indispensável a estes o conhecimento e o manejo técnico do material da arte como o preparo da tela, o de variar a natureza das tintas, dentre outros. Ainda em relação ao conhecimento técnico, Andrade reconhece e admira em Portinari o domínio sobre a tradição artística e os usos que dessa tradição o pintor se vale. De acordo com o crítico, este conhecimento técnico da tradição não é empregado por Portinari sem que passe por diversas experimentações, o que o leva à soluções e descobertas próprias sobre sua própria expressão artística

\footnotetext{
84، Aquela tradição que Almeida Júnior quis abrir, só agora parece retomada por este pintor, que em vez de perder tempo em buscar a cor do nosso céu, esta verdadeiramente fazendo obra de sentimento nacional." ANDRADE, M. O Estado de São Paulo, 1939.
} 
(...) a pesquisa tanto estética como técnica apaixona o pintor brasileiro, é o significado mesmo de sua obra, como caracterização da personalidade criadora. De forma que diante de qualquer solução alheia, mesmo das que Ihe desagradam por instinto como o Cubismo e o Abstracionismo, ou por consciência crítica como a arte de combate, Cândido Portinari é irresistivelmente levado a repensar essa experiência e a refazê-la por si mesmo. (ANDRADE, 1939, p. 107)

É interessante ressaltarmos por meio desta perspectiva que Mário de Andrade defende Candido Portinari - sua "unidade plástica" - das críticas que o acusavam de plágio, uma vez que ele refletirá em suas obras diferentes influências advindas dos movimentos de vanguarda europeus.

Já se tem dito de Cândido Portinari, ser ele sensível à influência de outros pintores e escolas. Há que distinguir, porém. Na verdade Candido Portinari jamais imita e siquer se apóia num exclusivo exemplo alheio pra criar. Tanto isto é certo que não é possível determinar, na multiplicidade de soluções estéticas diversas que a sua obra apresenta, qualquer influência que seja fundamental e permanente. (ANDRADE, Mário. in: Baile das quatro artes, 1939, p. 107)

A idéia de originalidade do artista é entendida em relação às suas experiências, "confrontando-as aos elementos e caracteres que lhe são pessoais, à essencialidade plástica, ao tradicionalismo, ao realismo, ao lirismo, ao nacionalismo, tão fortes em sua personalidade" ${ }^{85}$. Quanto ao estilo anti-acadêmico do pintor, é devido a seu intuito experimentador que Portinari será descrito como "um buscador inquieto e constante, através de escolas, épocas e artistas", um homem verdadeiramente interessado nas "verdades da criação humana" Tais traços serão novamente enfatizados ao longo do artigo, em que Mário de Andrade voltará a ressaltar sempre o "bom senso" e o conhecimento do pintor sobre o antigo, ou seja, a tradição artística e sua base realista ${ }^{86}$, com o intuito de enfatizar

\footnotetext{
${ }^{85}$ ANDRADE, M. de. "Candido Portinari". In: O Baile das Quatro Artes. Rio de Janeiro: Livraria Martins Editora, [s.d.], p. 107.

${ }^{86}$ ANDRADE, M. de. Op. cit., p. 107.
} 
as características que vislumbrava para o artista brasileiro e as obras, enquanto representação nacional e original.

Conforme Annateresa Fabris, Mário de Andrade escolhe um campo de referências em que à questão nacional associa a dimensão da consciência artesanal, e isso não será uma prerrogativa analisada apenas neste pintor. Segundo ainda esta autora, o nacional relacionado ao saber técnico responde antes ao projeto estético do autor e Portinari o conjuga exemplarmente em sua trajetória de arte e artesanato, tradição e nação, inconsciente coletivo e diálogo com outras culturas ${ }^{87}$.

Portinari permite a Mário de Andrade exteriorizar algumas de suas idéias fundamentais sobre a função da arte na sociedade contemporânea, sobre a possibilidade de conciliar belo e útil, categorias que a pregação vanguardista havia tornado antitéticas e que o escritor desejava reconverter em unidade. (Fabris, Annateresa. In: Portinari, amico mio: cartas de Mário de Andrade a Cândido Portinari, 1995, p. 30)

Portinari era ainda visto por Mário de Andrade como aquele que por ser dotado do saber técnico, reconduzia a pintura à seus problemas essenciais, à problemas de sua própria natureza plástica. Com a ênfase voltada à natureza plástica da pintura somos levados à problemas estéticos de cores, luzes, tons, etc., que voltam-se ao saber dos antigos em relação à experimentação e originalidade de suas obras. Da forma tão perseguida em Candido Portinari surge o assunto, de sua personalidade experimental, anti-acadêmica, é de onde advém o pintor moderno e nacional.

É importante tentarmos compreender que, desse caráter experimentador, que ora se aproxima mais ou menos do Cubismo, do Expressionismo, dentre outros, mas que deles recria o essencial, Andrade irá tentar conceituar o que daí emerge, que é o realismo de Candido Portinari. Para nosso crítico, a natureza para o pintor nada mais é que fonte primeira de inspiração, sugestionadora de

\footnotetext{
${ }^{87}$ FABRIS, Op.cit., p. 30.
} 
assuntos, de verdades transitórias, e essa natureza é em si, a finalidade do seu quadro: "ele parte sempre da natureza para encontrar a forma." 88

Para Mário de Andrade, Portinari reúne dois tipos de realismo, o estético, que influencia em suas soluções formais, e o psíquico, de onde deriva assim seu nacionalismo. Do realismo estético, verifica que os temas do artista - como o morro, a festa de São João, os retratos - derivam, antes de tudo, do trabalho plástico que realiza. Do psíquico, emerge a criação, que antes de referenciar a tipos - como os mestiços, os mamelucos, os caipiras, o branco, dentre outros - ou ao típico das situações regionais; constrói protótipos, cuja essência é brasileira.

Neste sentido, a obra com assunto de Candido Portinari é pra todos os artistas brasileiros uma lição genial de destino "poético" da arte. Quero dizer: sendo toda ela uma pesquisa primordial de forma plástica e beleza desrelacionada, pela íntima adequação entre forma e fundo, pelo equilíbrio entre o sentimento e sua expressão, muito mais que um elemento de caráter descritivo e analítico, a obra de Candido Portinari exerce uma função de vaticínio. Na sua procura incessante de beleza plástica, ele mantém aquele valor antigo de definição profética de uma vida milhor, com que a arte nasceu dos primeiros ritos místicos, com que a arte nasceu dos primeiros amores, dos primeiros sofrimentos do homem sobre a terra. (ANDRADE, 1939, p. 114)

Dessa maneira, Mário de Andrade relaciona à técnica, o aprimoramento formal; à forma, o assunto da arte, e com isso constrói seu ideal de beleza e função na arte, uma vez que estes são vistos como quesitos para a criação artística. Junto ao objeto e ao fazer artístico, nosso crítico relaciona ainda as qualidades pessoais do pintor, que para completar seu ponto de vista sobre a especificidade intrínsecamente humana da arte; é antes de tudo um homem de valores morais altos, o que o torna um exemplo como "destino de artista".

Candido Portinari, quer se admire quer não a obra completa dele, é sobremaneira respeitável. As suas qualidades pessoais de pintor, o entusiasmo infalível com que pôs toda a sua vida ao serviço da arte, a honestidade irrecusável com que se aplicou, sem descanso nem jamais se dando por satisfeito, a desenvolver a sua técnica, o elevadíssimo grau desta técnica, a humildade com que experimenta e ama a verdade: já por si, todas estas características da sua figura de artista fazem

\footnotetext{
${ }^{88}$ ANDRADE, Ibidem, p. 111.
} 
dele um alto valor moral, exemplar para os moços que desejem tentar o exercício das artes. (ANDRADE, 1939, p. 115)

\title{
José Sabogal: o pintor peruano
}

\begin{abstract}
Estas líneas quieren solo, a propósito de a publicación en "Amauta" de fotografías de algunos de sus cuadros, subrayar algunos valores primários de la obra de Sabogal, los que hacen de ella una obra-signo. Su intención está más allá de las intenciones especificas de la crítica. (...). Unicamente aspiro a percibir y traducir su espíritu y su significación.
\end{abstract}

(MARIÁTEGUI, José Carlos. La obra de José Sabogal)

A relação entre José Carlos Mariátegui e o pintor peruano José Sabogal (1888-1956) pode ser lida através das páginas da revista Amauta tanto no que se refere às diversas publicações que o editor nela promove sobre o artista, como nas constantes colaborações do pintor a este periódico. Ambos, intelectual e artista, encontram-se pelos interesses que regem suas obras, dentre os quais destacamos o da valorização da raça indígena, sintetizada pela figura hierática do índio, representada pelas ilustrações de Sabogal, bem como pelo significado expresso pelo próprio título dessa revista. O nome Amauta, que em quéchua significa o sábio, parece ter sido, conforme as palavras de Antonio Melis, uma proposta de Sabogal a Mariátegui, uma vez que aí se conjugariam - por meio do título da revista e das ilustrações de suas capas ${ }^{89}$ - os objetivos de uma vanguarda político-cultural que visava ressignificar a tradição peruana ${ }^{90}$.

\footnotetext{
${ }^{89}$ Conforme Alberto Tauro, as capas da revista Amauta sempre eram ilustradas com desenhos de José Sabogal, exceto as capas cuja imagem é a própria numeração. No entanto, podemos observar que as capas de numeração 13 e 18 foram ilustradas pela artista peruana Julia Codesino. Já na capa de número 24, o desenho é assinado pelo artista mexicano Diego Rivera. Ver figuras em anexo.

90 "Parece que la propuesta de llamar Amauta la nueva revista vino del pintor indigenista José Sabogal, el mismo que dibujó su carátula, así como había trazado anteriormente el logo de la Editorial Minerva, fundada en 1925 por el mismo Mariátegui con su hermano Julio César." MELIS, Antonio. "El indigenismo vanguardista de José Carlos Mariátegui". In: El Indigenismo en diálogo.
} 
La elección del nuevo título conlleva claramente la decisión de enraizar la vanguardia político-cultural peruana en la tradición andina. Al mismo tiempo, sugiere un proceso de resemantización del antiguo término incaico, que designaba al sabio consejero del monarca, aludiendo posiblemente a la nueva función que debe cumplir el intelectual en el proyecto revolucionario moderno. (MELIS, 2001, p. 108)

A temática indígena é recorrente no Peru desde o final do século XIX e o nacionalismo irá concorrer ao longo do tempo com diversos fatores sócioeconômicos que, de acordo com os intuitos de uma pequena burguesia, irão modificar a realidade local, em relação à metrópole espanhola, tanto no plano econômico, como no cultural ${ }^{91}$.

(...) en lo político como la cuestión agraria del problema de la tierra, en lo educativo como una nueva cruzada reformista, en lo literario como una modificación nativista del ultraísmo español y en lo pictórico como una cruzada de aprehensión de la imagen física del pueblo quechua. (LAUER, 1976, p. 84)

Para Mariátegui o indigenismo autêntico não era apenas um tema ou motivo, seja literário ou plástico, mas sim uma obra política e econômica de reivindicação, um modo de analisar e interpretar um Peru mais profundo, no qual se pudesse compreender o presente, por meio do reconhecimento do passado incaico: "El problema de nuestro tiempo no está en saber cómo ha sido el Perú. Está, más bien, en saber cómo es el Perú". (MARIÁTEGUI, 1928). Pode-se dizer que nesta mesma direção encontra-se o pintor peruano José Sabogal, cujas pinturas e gravuras partem do tema indígena para uma compreensão mais ampla da realidade peruana: "Soy un peruano que capta los valores esenciales de su

Canárias-América 1920-1950. Org. Maria Candelaria Hernández Rodríguez. Canarias: Centro Atlántico de Arte Moderno/ Instituto de Canárias "Cabrera Pinto", 2001, p. 108.

91 "(...) En esos primeros decenios - siglo XX - la cultura dominante ha perdido todo interés científico por el país y gobierna a las últimas sombras del imperialismo inglés una oligarquía civilista cuya idea de lo nacional se circunscribe a la reproducción de la institucionalidad europea en todos los ámbitos. Sin embargo, desde comiezos de la segunda década se produce un cambio fundamental en la estructura productiva nacional, que tendrá sus frutos políticos en la tercera década: la penetración del enclave norteamericano al campo peruano y el inicio del oncenio de Leguía." LAUER, Mirko. Introduccion a la Pintura del Siglo XX. Lima: Mosca Azul Editores, 1976, p.84-85. 
pueblo. Más ampliamente, soy un americano" (SABOGAL, apud Canárias, p. 34). Tendo em vista os interesses desses autores e de suas obras, estudaremos as relações entre José Carlos Mariátegui e José Sabogal - do mesmo modo como estabelecemos o encontro entre Mário de Andrade e Candido Portinari - através das perspectivas entre a tradição e a modernidade, bem como de seus intuitos estéticos e ideológicos.

De acordo com Mariátegui, a autonomia artística de Sabogal se deve a sua formação técnica e a sua vivência européia, quando aprendeu principalmente que toda grande criação artística possui uma raiz vital, que é sua relação com a história.

No es el interés genérico del pintor por lo pitoresco ni por lo característico, lo que ha movido a este artista admirable a encontrar la riqueza plástica de lo autóctono. Sabogal siente sus temas. Se identifica con la naturaleza y con la raza que interpreta en su cuadros y en sus xilografías. (MARIÁTEGUI, [1928], 1990, p. 93)

José Sabogal viajou para a Europa entre 1909 e 1911, estabelecendo residência mais prolongada na Espanha, onde estudou com Ignacio Zuloaga e os irmãos Valentín e Ramón de Zubiaurre. Depois da Espanha, foi à Argentina, onde morou por algum tempo na província de Jujuy. Sua primeira exposição em Lima ocorreu em 1917, na Sala Brandes, e foi apresentada pelo pintor e crítico de arte Teófilo Castilho, sendo recebida com surpresa e inquietação pelo público, devido à temática de cunho nacionalista e à técnica ${ }^{92}$, de acordo com a vontade de renovação que agitava o clima ideológico junto ao ambiente limenho. Em 1922 o pintor tornou-se professor na Escuela Nacional de Bellas Artes, e em 1932, com a morte do fundador desta escola, Don Daniel Hernández, Sabogal é nomeado o novo diretor desse centro de estudos artísticos ${ }^{93}$. Ao assumir o cargo promoveu mudanças profundas nos rumos do ensino da arte no Peru, que do academicismo

\footnotetext{
92 "Y si Europa no se lo ha asimilado, en cambio el se ha asimilado a Europa, en la formación de su técnica". MARIÁTEGUI. "La obra de Jose Sabogal". In: El artista y la Epoca, 14 ed. Lima: Biblioteca Amauta, 1990, p. 93.

${ }_{93}$ Pintura contemporânea: 1920-1960. José Antonio de Lavalle e Werner Lang (org.). Lima: Banco de Crédito del Perú en la Cultura, 1998, p. 24-28 (Colección Arte y Tesoros del Perú)
} 
e pós-impressionismo partiu para a definição do localismo, indigenismo e nacionalismo cultural como eixos centrais de pesquisa artística ${ }^{94}$.

De acordo com Mariátegui, a interpretação da raça autóctone expressa nas obras de Sabogal se contrapõe, todavia, a toda uma corrente indigenista que se formou a partir da influência desse artista. Para o crítico, essa nova geração não compreendeu ou não interpretou suficientemente a representação do "sentimento incaico" de Sabogal.

Después de él, se ha propagado la moda del indigenismo en la pintura, pero quien tenga mirada penetrante no podrá confundir jamás la profunda y austera versión que de lo índio nos da Sabogal, con la que nos dan tantos superficiales explotadores de esta veta plástica, en la cual se ceba ahora hasta la pintura turística." Ibidem, p. 93.

A que se deve tal observação do crítico, e quais seriam assim as qualidades que deve conter uma obra de arte para que atinja uma forma expressiva de verdadeiro "sentimento incaico"? Se por um lado Sabogal é, a princípio, referência para todo um grupo de intelectuais e artistas, por outro, foi um pintor freqüentemente atacado por alguns $\operatorname{críticos}^{95}$, daí que seja possível perguntar quais são as relações entre forma e conteúdo, de acordo com os valores implícitos à obra deste artista, que sustentam a afinidade revelada entre a crítica de José Carlos Mariátegui e a pintura de José Sabogal.

Do encontro entre o intelectual e o artista podemos ainda averiguar como se formava o propósito de modernização da cultura peruana, tendo em vista a necessidade de se redimensionar o imaginário dessa sociedade, até então construída sob as influências de base econômica, política e cultural advindas da metrópole espanhola. Nesse sentido, as análises de Mariátegui em relação à arte e à literatura são fundamentais na história do Peru, inclusive porque os textos de Siete Ensayos de Interpretacion de la Realidad Peruana estão acompanhados de mais algumas tentativas críticas desse período de interpretar os fenômenos

\footnotetext{
${ }^{94}$ LAUER, M. Op. cit., p. 102.

95 "EL INDIGENISMO EM DIÁLOGO: CANÁRIAS 1920-1950", 2001, Canárias: Centro Atlantico de Arte Moderno: Las Palmas de Gran Canaria; Insituto de Canairas "Cabrera Pinto": San Cristóbal de La Laguna, TenerifeHERNÁNDEZ, 2001, 1 v., Catálogo de exposição, p. 45.
} 
culturais peruanos de maneira orgânica, ou seja, em oposição a parâmetros culturais anteriores, e assim pensados e organizados sob os próprios pontos de vista internos ${ }^{96}$. Dessa maneira, podemos verificar também como a práxis política de Mariátegui, de cunho declaradamente socialista, e que travava uma luta contra a oligarquia de origem espanhola dominante, iria influenciar a perspectiva de formação de uma cultura peruana, como também a de sua relação com outras culturas dentro e fora do Peru ${ }^{97}$. Este projeto pode ser acompanhado através das páginas da revista Amauta, que abarcava questões políticas e assuntos sociais, como as ligadas aos problemas indígenas, através da seção "Boletín de Defesa Indígena", e outra de debates econômicos, sob o título "Vida económica". Sobre cultura tem-se, além das várias exposições divulgadas em todos os exemplares da revista, e da constante participação de escritores e poetas,a seção denominada "Panorama móvil", cujo objetivo era o de informar de maneira dinâmica e diversificada assuntos que tratavam da atualidade literária e política, e que veiculava informações sobre as atividades de escritores e artistas da atualidade mundial; bem como "Libros y Revistas", que foi a única seção de Amauta que permaneceu ao longo de toda a existência deste periódico ${ }^{98}$. Além de conter uma gama bastante variada de temas, Amauta contou ainda com a colaboração de escritores de diferentes partes do mundo, como Waldo Frank, Romain Rolland, Jorge Luis Borges, Vladimir Maiakovski, Leon Trotsky, dentre outros.

Dessa maneira, podemos depreender que a relação entre arte e política será abordada de maneira constante e como um fenômeno indissociável nas atuações de José Carlos Mariátegui. Por isso, a idéia de uma época "decadente"

\footnotetext{
96 "Sería más exacto considerarlo como una de las partes en la polémica contra la interpretación tradicional de la cultura peruana, entonces defendida por José de La Riva-Agüero y la llamada generación del 900 . Es preciso señalar que en esta pugna Mariátegui representó la oposición más clara y combativa, pero que los trabajos de jóvenes acadêmicos como Basadre, Sánchez y el resto de la generación universitaria de ese tiempo eran también ellos cuestionamientos de la interpretación de la cultura peruana como una prolongación ultramarina de la hispanidad." LAUER, Mirko. Introducción a la pintura peruana del siglo XX. Lima: Mosca Azul Editores, 1976, p. 16-17.

97 Ibidem, p. 17.

${ }^{98}$ Estas seções não são permanentes em Amauta. O "Boletín de Defesa Indígena" iniciou a partir do número 5 e foi publicado seis vezes de maneira esporádica. "Vida económica" surge a partir do número 10, em publicação à parte de Amauta, e é veiculada até o número 16. "Panorama móvil" surge a partir do número 17 e se torna permanente na revista. TAURO, Alberto. Amauta y su influencia. Lima: Editora Amauta, 1989, p. 15-17.
} 
e/ou de uma época "revolucionária" pode ser relacionada tanto a uma vanguarda artística como política: "esta época de compleja crisis política es también uma época de compleja crisis artística" $"$.

Para esse autor, devido ao vínculo entre arte e vida, os artistas nutrem-se consciente ou inconscientemente de suas épocas. Podemos avaliar estas questões mediante o texto Post-Impressionismo y Cubismo (1924), no qual Mariátegui reflete sobre a relação entre forma e conteúdo na arte como um sintoma das relações históricas formadas a partir de movimentos "externos" e "internos", os quais nos parecem vinculados às transformações ocorridas respectivamente tanto nos aspectos político-sociais, como nos da linguagem.

No envejecen únicamente las formas políticas de una sociedad y una cultura; envejecen también sus formas artísticas. La decadência y el desgaste de una epoca son integrales, unanimes. (MARIÁTEGUI,[1924], 1959, p. 60)

Nesse artigo o crítico peruano irá traçar como perspectiva de observação da arte moderna dois pontos de vista sobre a arte e a sociedade, pautados respectivamente nas observações que colhe nas teorias do filósofo alemão Oswald Spengler (1880-1936) ${ }^{100}$, e nas formulações do crítico de arte espanhol Eugenio d'Ors (1881 - 1954). Sobre Oswald Spengler, Mariátegui cita, desenvolve e concorda com parte de suas posições, especialmente em relação à análise da arte moderna, vista como uma arte vazia de valores e sentidos culturais, através da qual se criam estilos - voltados à imitação de motivos arcaicos e exóticos - que expressam apenas uma moda, sem qualquer profundidade simbólica ${ }^{101}$.

\footnotetext{
${ }^{99}$ MARIÁTEGUI, José Carlos. "Post-impressionismo y cubismo". In: El artista y la época. 14 ed. Lima: Biblioteca Amauta, 1990, p. 60.

100 De acordo com Estuardo Núñez, Mariátegui: "Llegó a leer en alemán "Das Finanz-Kapital" de Hilferding y también "Untergang des Abendlandes" de O. Spengler, cuyos ejemplares anotados tuvimos oportunidad de revisar em casa de Mariátegui". NúÑEZ, Estuardo. En Alemania. In: La experiencia europea de José Carlos Mariátegui. Lima: Amauta, 1978, p.58.

${ }^{101}$ Mariátegui transcreve uma citação do filósofo alemão Oswald Spengler, autor dentre outras obras de "Der Untergang des Abendlandes" (1922), em português "O Declínio do Ocidente", traduzido também como "A Decadência do Ocidente". No caso, transcrevemos aqui o trecho referido: "la existencia no tiene forma interior; el arte de la gran urbe es una costumbre, un lujo, un deporte, un excitante; los estilos se ponen de moda y varían rápidamente (rehabilitaciones, inventos caprichosos, imitaciones); no tienen ya contenido simbólico". MARIÁTEGUI, José Carlos.
} 
La pintura y la música, por ejemplo, están impregnadas de orientalismo. Los colores y los ritmos rusos invaden París y Berlín, Londres y Roma. La pintura japonesa ejerce una extensa influencia sobre varios sectores del arte contemporáneo. Simultáneamente, otros sectores se tiñen densamente de primitivismo." (MARIÁTEGUI, [1924], 1990, p. 61)

Mariátegui contrapõe a crise existente no período moderno, abordada por Spengler, aos apontamentos feitos por Eugenio d'Ors. Se para Spengler toda a arte é imitativa, e os assuntos são os mesmos ao longo do tempo, para d'Ors, no entanto, o que se transforma não são as referências advindas da tradição artística, mas sim a sensibilidade do artista em representá-las, daí que haja a necessidade de buscar novas técnicas e formas de expressão ${ }^{102}$.

Las botellas, los vasos y las manzanas no han variado en cinco siglos; pero la sensibilidad de los hombres sí. Y el mundo exterior de un artista de hoy no se parece casi al mundo exterior de un artista del Renacimiento. La vida actual tiene elementos físicos absolutamente nuevos. Uno de ellos es la velocidad. El hombre antiguo marchaba lentamente, que es, según Ruskin, como Dios quiere que el hombre marche. El hombre contemporaneo viaja en automóvil y en aeroplano. (MARIÁTEGUI, [1924], 1990, p. 62)

Diante desta perspectiva, entre o declínio político e social de uma civilização, no caso após a Primeira Guerra Mundial, e a crise em relação à representação artística, Mariátegui aponta ainda outro dado importante a ser analisado sobre as manifestações desenvolvidas pelas vanguardas artísticas: o de que por mais simples ou estranhas que possam parecer as suas 'formas' de representação, os artistas inseridos no contexto das vanguardas européias ainda assim dominam a 'técnica' e os recursos acadêmicos. "Picasso tiene dibujos más puros y clásicos que los de Ingres y los de Raphael"103. O domínio técnico, o rigor com o saber, como prerrogativa entre as formas clássicas e modernas - assim

"Post-Impressionsimo y Cubismo". In: El artista y la Epoca, 14 ed. Lima: Biblioteca Amauta, 1990, p. 60.

102 "?Qué buscan los artistas actuales en esta persistente producción de "naturalezas muertas"? Sería estólido atribuirles limitadamente una frívola adhesión a una moda. Esos artistas aprenden a ver y copiar la naturaleza de una manera nueva." Ibidem, p. 62.

103 Ibidem, p. 63. 
como para Mário de Andrade - também são valorizados por Mariátegui nos artistas que analisa, e este é mais um dos fatores que o aproximam de José Sabogal.

Ao nos referirmos às investigações de Mariátegui sobre o contexto histórico e as vanguardas artísticas européias, vale ressaltar que o escritor peruano debate, em grande parte de seus textos, conceitos de autores que publicavam suas idéias na Revista de Occidente (1923-1936) ${ }^{104}$. Esta revista, editada na Espanha - e cujo título alude à obra de Oswald Spengler, denominada A Decadência do Ocidente ${ }^{105}$

- traz implícito o propósito de José Ortega y Gasset, seu editor, de inserir a Espanha em um contexto mais amplo de modernização, no qual as diferenças entre países e suas tradições culturais fossem vistas através de um mapa imaginário, traçado a partir da perspectiva entre Ocidente e Oriente ${ }^{106}$. Esta "ausência de fronteiras" entre países - no caso, entre os europeus - configurava um projeto, do editor desta revista, de inserir e equiparar a cultura espanhola às vanguardas francesas e alemãs, que sob seu ponto de vista dominavam a cena artística européia ${ }^{107}$. Na coletânea de textos presentes em El artista y la Época no qual consta o artigo Post-impresionismo y cubismo - podemos perceber que Mariátegui estabelece uma rede de debates com outros intelectuais - dentre os

${ }^{104}$ A Revista do Occidente foi reeditada na Espanha pelos descendentes de Ortega y Gasset, passando, a partir de 1963, por duas diferentes etapas. A primeira sob a direção de José Ortega Spottorno e a segunda, por Soledad Ortega Spottorno, ambos filhos de José Ortega y Gasset.

${ }^{105}$ Conforme aponta a pesquisadora Flávia Ferreira dos Santos, Ortega y Gasset, apesar de discordar das idéias de Spengler no que se refere à decadência da cultura ocidental, reconhece a importância desta problemática: "De fato, ao publicar a referida coletânea de "ideas del siglo XX" Ortega "escribe um prólogo general en el que protesta contra el anuncio del fracaso de la cultura, afirmando que el siglo XX, por el contrario, ha producido obras características de una renovación del espiritu humano" (...). Discorda Ortega, portanto, da "morte da civilização ocidental", o que não significa negar a existência de uma crise (...)". SANTOS, Flávia Ferreira dos. "A Revista de Occidente e suas estratégias de legitimação: um estudo do ano de 1929". Rio de Janeiro, 2005. 153 f. Dissertação (Mestrado em Letras neolatinas) - Faculdade de Letras, Universidade Federal do Rio de Janeiro, p. 54-55.

106 "Ao deslocar a questão para o ocidente, a revista procurou "construir um mapa" do qual a Espanha e a revista podiam formar parte, associados ao novo panorama dessa cultura. Ao redefinir seu espaço, ao mesmo tempo em que se afastavam da visão de uma cultura "destruída" pela guerra também resolviam o problema interno da geração de intelectuais anterior, que acreditava na incompatibilidade entre a adoção do modo de vida moderno europeu e a manutenção das "tradições" do povo espanhol. A necessidade de europeização da Espanha cede lugar ao "novo cosmopolitismo do pós-guerra" anunciado nos 'Propósitos' “. Ibidem, p. 54-56.

107 "No mapa delineado pela revista, o tratamento que França e Alemanha receberam respondia às necessidades internas do campo intelectual espanhol de levar a cabo o processo de 'reconhecimento e confronto com o outro' inerente ao significado do 'novo cosmopolitismo moderno' (...). Questionar o modelo francês e inserir como alternativa o espírito científico alemão constituía uma das operações básicas de renovação do Ocidente." Ibidem, p. 61. 
quais citamos Eugenio d'Ors - colaboradores desta Revista. Este periódico, de grande importância e circulação tanto na Espanha, como na América Hispânica, se interpõe como um ponto de contato bastante valioso a ser estabelecido, não só por ser um veículo de informação importante para a época, como também pelas possíveis analogias entre o projeto estrutural desta revista e o da revista Amauta. Dentre algumas semelhanças destacamos o caráter cosmopolita que se revela em seu projeto, com vários colaboradores pertencentes a diversas nacionalidades; seu desejo de fazer a modernidade espanhola participar de um contexto mais internacional; bem como por abordar discussões sobre as vanguardas artísticas, a literatura, a crise no Ocidente, as teorias da física sobre a relatividade, dentre outros assuntos. Já não podemos afirmar a mesma conformidade quanto a seu projeto ideológico; no entanto, por não ser este o foco de nosso assunto, nos limitamos ao longo de nosso texto a apontar apenas algumas das questões que permeiam as discussões travadas entre José Carlos Mariátegui e o editor desta revista, José Ortega y Gasset.

Até o momento verificamos que Mariátegui procura analisar a arte por intermédio de perspectivas históricas, pensando como a crise da época moderna incide sobre a arte e também sobre a sensibilidade e a técnica do artista. Para o crítico, a arte não é feita apenas das modificações técnicas. O artista como fruto de uma época é quem cria as formas e lhes dá significado. A postura dos artistas de vanguarda na busca pelo novo leva a arte, no entanto, a tornar-se cada vez mais intelectualizada. Neste sentido Mariátegui está de acordo com Ortega y Gasset sobre a impopularidade da arte de vanguarda, pois: "se trata de un arte nuevo e insólito en su espírito y en su matéria, en su contenido y en su forma. El público, por eso, no lo discute: repudia integralmente". (apud MARIÁTEGUI, [1924], 1990, p.64)

Ao tomarmos esta passagem em que Mariátegui cita o pensamento de Ortega y Gasset, poderíamos nos perguntar como o filósofo espanhol compreende o distanciamento do público frente à nova arte. No texto de Ortega y Gasset, sobre A Desumanização da Arte (1925), vemos que a rejeição da arte nova pela maioria 
do público se dá principalmente pela incapacidade deste em entender a arte dentro de seus códigos próprios, ou seja, apenas pela questão formal. Assim, o público:

(...) somente tolerará as formas propriamente artísticas, as irregularidades, a fantasia, na medida em que não interceptem sua percepção das formas e peripécias humanas. Uma vez que esses elementos puramente estéticos dominem e ele não possa captar bem a história de João e Maria, o público fica desnorteado e não sabe o que fazer diante do cenário, do livro ou do quadro. (ORTEGA Y GASSET, 2005, p. 26)

Seria somente o caráter anti-realista da arte nova o que distanciaria o interesse e a compreensão do público - público este que, segundo Ortega y Gasset, separa-se entre "aqueles que apreciam" e "aqueles que não apreciam" certa obra -, perante as vanguardas?

Já o modo de compreender esta questão distancia-se das prerrogativas de Mariátegui sobre a arte moderna, pois para este os aspectos formais desenvolvem-se dentro de um processo "coerente, lógico e orgânico", apesar de sua aparente "desorganização e anarquia". A realidade estética pode ser observada, para este crítico, por meio de uma relação "cíclica"108 dos acontecimentos, engendrados por rupturas e contraposições internas, intrínsecas aos procedimentos artísticos.

El impresionismo, que dió al arte una orientación realista, exaltó el valor del color y de la luz y desconoció el valor de la línea. Las figuras y las cosas perdieron su contorno. El cubismo, desde este punto de vista, representó una reacción contra la vaguedad y la incorporeidad de las formas impresionistas. Se preocupó exclusivamente de los planos y de la línea. El post-impresionismo rectifica el error del impresionismo. Su esencia es la misma del impresionismo; pero su técnica no. Es una técnica corregida, revisada, que concede a la línea la misma categoría plástica que al color.

108 “(...) Uno de los leaders del arte de vanguardia, Francis Picabia, dice que la historia del arte se condensa en períodos de revolución y de conservación. A un período romántico sigue un período clásico. Un período romántico es tempestuoso, desordenado, caótico. Es, sincrónica y revueltamente, de destrucción y de construcción. Un período clásico, en cambio, es sereno, regular, apacible. Encierra un trabajo de pacífica elaboración y desarollo de un estilo. Actualmente atravesamos un período romântico y revolucionário." Ibidem, p. 61. 
El post-impresionismo, además, es sintetisa. Es una de las manifestaciones de esa tendencia a la estilización y a la síntesis que domina el arte de hoy y que resucita algunas formas arcaicas. (MARIÁTEGUI, [1924], 1990, p. 63)

No entanto, como a arte para Mariátegui não deve ser desinteressada da vida, e se o público não a compreende, é porque as vanguardas, diferentemente da arte do século XIX, foram engendradas sob uma nova concepção. No texto El Expresionismo y el Dadaismo, verificamos que José Carlos Mariátegui avalia que as fases da arte de vanguarda são fenômenos de acordo com outras fases do espírito e mentalidade contemporâneos, como o dadaísmo, que surge como um movimento de evasão ao pensamento racionalista: "Asesinemos la inteligencia si queremos comprender la belleza"109. Assim, se a "incoerência" dadaísta é a de uma atitude que é ao mesmo tempo "humorista" e "niilista", "polêmica" e de "desordem", é porque estes sintomas são próprios ao artista que vive o século $\mathrm{XX}^{110}$. Se o dadaísmo parece ao público uma arte "defeituosa" ou "equivocada", ela nada mais é que simples reflexo de uma época em crise ${ }^{111}$. Assim o crítico verifica, na relação entre a forma e o conteúdo da arte moderna, correlacionandoos aos fatores externos e internos da sociedade, o que estes refletem junto ao processo da criação artística:

Dentro del concepto vigente del arte, la forma es la expresión del contenido. Dentro del concepto novísimo, la forma es todo: es forma y es contenido al mismo tiempo. La forma resulta el único fin Del arte. (MARIÁTEGUI, [1924], 1990, P. 68)

Nessa perspectiva, o escritor peruano analisa as diferenças entre o século XIX e XX, através da idéia mais ampla de expressão artística, caracterizada pelo

\footnotetext{
${ }^{109}$ MARIÁTEGUI, José Carlos. "El Expresionismo y el Dadaismo". In: El artista y la Epoca, 14 ed. Lima: Biblioteca Amauta, 1990, p. 69.

110 Ibidem, p. 67.

${ }^{111}$ De acordo com Giulio Carlo Argan, o dadaísmo se coloca como contestação da própria arte, diferentemente das outras correntes deste período, que "nascem da vontade de conhecer, interpretar a realidade e dela participar". ARGAN, Giulio Carlo. Arte Moderna. Trad. D. Bottmann e F. Carotti. São Paulo: Companhia das Letras, 1992, p. 353.
} 
impressionismo e o expressionismo. Dessa maneira, se o impressionismo é essencialmente "naturalista e objetivista", o expressionismo é mais "subjetivista":

El tema de la obra de arte impresionista es el modelo. El tema de la obra de arte expresionista es lo que el modelo sugiere, lo que el modelo suscita en el espíritu del artista. El modelo, en el arte expresionista, deja de ser específicamente un modelo. Pasa de su categoría primaria y única a una categoría secundaria. En el expresionismo el eje del arte se desplaza del objeto al sujeto. El impresionismo es sólo impresión. El expresionismo es solo expresión. (MARIÁTEGUI, [1924], 1990, p. 68)

Ao tomarmos a dicotomia entre o impressionismo e o expressionismo como representantes de características mais objetivas e subjetivas dos procedimentos técnicos e expressivos, poderíamos traçar essa mesma dualidade quanto ao contexto político e histórico. Uma vez que a Europa, neste período, é tomada culturalmente como modelo hegemônico aos países latino-americanos, nos perguntamos se há alguma diferença quanto ao modelo da França e o da Alemanha - que tange à influência da cultura francesa "versus" a cultura germânica $^{112}$ - para a América Hispânica. De acordo com o projeto estético e ideológico de Mariátegui, podemos analisar que sim, ainda que ele tenha uma postura e mente de formação tão ampla de referências. Conforme Estuardo Núñez, Mariátegui "afinó su espíritu en Francia, colmó su experiência en Italia y decidió su destino en Alemania" (NúÑ̃EZ, 1978).

Os primeiros contatos de Mariátegui com a cultura alemã se deram ainda antes de sua viagem à Europa, através de alguns pensadores e poetas alemães, como Nietzsche e Heine. Já conhecendo a importância da militância alemã e sua contribuição ao socialismo, não só pelos fundadores do pensamento marxista, Marx e Engels, mas também através do grupo "Spartakus" - que dentre seus participantes envolvia personalidades como Rosa Luxemburgo e Karl

112 "El movimiento expresionista exhibe, entre otros, el mérito de haber colocado a Alemania en rango principal en la pintura, después de un largo período en que permaneció, a este respecto, relegada a segundo orden. La época del impresionismo se caracteriza como la de la hegemonía de la pintura francesa. Monet, Renoir, Cézanne, Degas, etc., Ilenan con su trabajo y con su influencia un entero capítulo de la pintura moderna." MARIÁTEGUI, José Carlos. "'Der Sturm' y Herwarth Walden". Idem, p. 79. 
Liebknecht $^{113}$-, Mariátegui decidiu, mesmo antes de viajar, por visitar este país, onde permaneceu do final de 1922 até o início de $1923^{114}$. Durante sua estadia em Berlim, o autor peruano travou contato com diferentes intelectuais, bem como com várias das vanguardas artísticas, dentre as quais o expressionismo alemão, por meio de um de seus grandes divulgadores, que foi Herwarth Walden, diretor da revista e galeria Der Sturm ${ }^{115}$.

Cubistas y dadaístas, futuristas y constructivistas, sin excepción, han tenido en Der Sturm albergue fraterno. Herwarth Walden, director de Der Sturm, no se há dejado nunca monopolizar por una escuela. Vanguardista auténtico, de rica cultura, de aguda visión y de penetrante inteligencia, su empeño consiste en cooperar, sin limitaciones, a la creación de un nuevo sentido artístico. Pero el hecho de que el expresionismo haya nacido en Alemania, lo ha vinculado particularmente a los hombres y a las obras de esta tendencia artística y literaria. (MARIÁTEGUI, [1927], 1990, p. 79)

Não apenas Herwarth Walden, mas também outros integrantes da corrente expressionista, como o pintor George Grosz, contribuíram posteriormente com artigos para a revista Amauta. A ligação de Mariátegui com o expressionismo foi de grande afinidade diante do caráter político-social deste grupo ${ }^{116}$. No texto dedicado ao pintor alemão Henrich Zille, Mariátegui averigua a relação de como o "clima histórico" e o "gênio nacional" alemães são propícios à arte social: "un pueblo, una época han menester siempre de una mitologia"117. Por isso, as obras

${ }^{113}$ Cf. Esturdo Núñez, dentre as fontes de informação no Perú sobre o socialismo alemão está, desde 1918, o periódico Nuestra Epoca, editado pelo próprio Mariátegui. NÚÑEZ, Estuardo "En Alemania". In: La experiência europea de José Carlos Mariátegui. Lima: Amauta, 1978, p. 51.

114 "Creía - Mariátegui - firmemente que Alemania sería después de Rusia, el segundo país soviético y lo seguía creyendo aún después de su regreso al Perú. No tuvo tiempo para ver desvanecida esa posibilidad con el acceso al poder del nazismo en 1933." Ibidem, p. 60.

${ }^{115}$ Cf. Estuardo Núñez, após seu retorno da Europa, Mariátegui recebia os seguintes periódicos alemães: Der Querschnitt, Eulenspiegel, Der Sturm, Unter den Banner des Marxismus, Die Weissen Blaetter. Ibidem, p. 61.

116 "La posición de Walden es hasta hoy una posicion de extrema izquierda, no por una fácil adhesión a ultraísmos formales, sino por una reiterada afirmación de un espíritu realmente revolucionário". MARIÁTEGUI, José Carlos. "'Der Sturm' y Herwarth Walden”. Idem, p. 80.

117 MARIÁTEGUI, José Carlos. "Henrich Zille". In: El artista y la Epoca, 14 ed. Lima: Biblioteca Amauta, 1990, p. 76. 
de Kaethe Kolwitz ${ }^{118}$, George Grosz, Henrich Zille serão vistas como vivamente representativas de uma época, devido às característica técnicas e assuntos apresentados nas obras destes artistas: de denúncia contra a guerra, a fome, a miséria e a injustiça social; bem como a crítica mordaz à burguesia e a profunda reflexão sobre a condição proletária. Para compreendermos no que residem especificamente os valores atribuídos a estas obras, tomemos as argumentações do crítico peruano no que se refere à oposição que faz entre as obras de Grosz e Zille e, a partir delas, poderemos retirar algumas idéias para a nossa posterior análise sobre a importância da construção de um mito em relação a cada época da sociedade.

Segundo Mariátegui, a diferença essencial entre as obras de George Grosz e Heirinch Zille reside na representação "fantástica" e "romântica" do primeiro, e no profundo "realismo" do segundo. Grosz interpretava de forma sarcástica o drama do proletariado e sua "força patética", enquanto a burguesia alemã era vista em sua "abundância glutona" e "perversidade leviana". Já Zille interpretava em suas obras o drama proletário de forma também patética, mas não isenta de certo lirismo. A burguesia era um tema por ele também abordado, no entanto, representado em sua "perversidade animal e rudimentar"119.

Grosz, de origen burgues, puede sentir satánicamente, con refinada ironía, lo grostesco y lo mórbido de sus personajes, los clientes del café Schotendalm. Zille, hijo de un cerrajero y de la hija de un minero, es en su traducción de estos tipos algo rudo y basto. (MARIÁTEGUI, [1929], 1990, p. 78)

Poderíamos dizer que a concepção de uma arte de cunho mais "fantástico" ou mais "realista", para Mariátegui, está em relação à condição da arte, e do artista, no modo como estes se aproximam mais ou menos da vida. Tomando de empréstimo um trecho em que Mariátegui cita Oscar Wilde, o autor inglês analisa o período a eles contemporâneo como "uma época propícia ao paradoxo". Este

118 "Quero atuar no meu tempo, no qual a humanidade está tão desorientada e precisando de ajuda." Conforme anotação colhida no diário da artista, em 1922. SIMONE, Eliana de Sá Porto. Käthe Kollwitz. São Paulo: Ed. da Universidade de São Paulo, 2004, p. 17.

${ }^{119}$ Cf. Mariátegui. Op. cit., p. 77. 
paradoxo, a nosso entender, refere-se ao momento em que a arte moderna, ao libertar-se da natureza e voltar-se à expressão do sujeito sobre o mundo, fará surgir diferentes "realidades", relativas ao modo como cada artista se relaciona e interpreta o seu meio social. De acordo ainda com Oscar Wilde: "No es cierto, que el arte copia a la Naturaleza. Es la Naturaleza la que copia el arte".

El realismo nos alejaba en la literatura de la realidad. La experiencia realista no nos ha servido sino para demonstrarnos que sólo podemos encontrar la realidad por los caminos de la fantasía. Y esto ha producido el suprarrealismo que no es sólo una escuela o un movimento de la literatura francesa sino una tendencia, una vía de la literatura mundial. (MARIÁTEGUI, [1926], 1990, p. 23)

Também as diferenças de classes apontadas pelo crítico peruano levamnos a pensar a condição na arte de Grosz e de Zille de estabelecerem uma crítica cujo ponto de vista propunha uma relação de "distanciamento" ${ }^{120}$ da "realidade vivida", relação esta que venha a influenciar tanto na escolha da linguagem empregada, como na representação sobre a "realidade representada". No caso destes artistas, seja o caráter "fantástico" - ou ainda, poderíamos dizer, de certa "deformação da realidade" - empregado por um, seja o caráter "realista" empregado pelo outro ${ }^{121}$, ambos realizaram uma arte social cujo sentimento exprimia profundamente o "espírito de uma época" socialista.

Assim, após percorrermos os caminhos que levam o artista a relacionar-se com seu tempo e a partir daí tornar-se mediador das realidades objetiva e subjetiva, através de sua expressão artística, voltamos à nossa proposta inicial, para estabelecermos ligações entre as teorias apresentadas e a "época dos nacionalismos" junto à obra de José Sabogal.

\footnotetext{
${ }^{120}$ Podemos fazer uma analogia ao termo "distanciamento" empregado neste contexto através do efeito de distanciamento crítico (Verfremdungseffekt), proposto por Bertold Brecht.

121 "Pero la ficción no es libre. Más que descubrir-nos lo maravilloso, parece destinada a revelarnos lo real. La fantasía, cuando no nos acerca a la realidad, nos sirve bien poco. Los filósofos se valen de conceptos falsos para arribar a la verdad. Los literatos usan la ficción con el mismo objeto. La fantasía no tiene valor sino cuando crea algo real. Esta es su limitación. Este es su drama". MARIÁTEGUI, José Carlos. "La realidad y la ficcion". In: El artista y la Epoca, 14 ed. Lima: Biblioteca Amauta, 1990, p. 23.
} 
Em 1928, através de um artigo intitulado La obra de Jose Sabogal, podemos acompanhar a crítica de José Carlos Mariátegui à exposição que o pintor peruano faria brevemente em Buenos Aires, cidade que, segundo suas palavras, é "el primer mercado artístico y literário de la América Latina"122. Para o crítico os quadros dessa exposição constituem um conjunto de obras que representam os "fatores espirituais" da nova peruanidade. A figura do índio será assim um assunto recorrente, devido à necessidade da época de reivindicação quanto à formação de um sentimento que influísse na vida social do peruano. Para Mariátegui o problema indígena é presente na vida do peruano em quase todos os âmbitos da vida social, como na política, na economia, na sociologia, como também na literatura e na arte ${ }^{123}$.

Lo que dá derecho al índio a prevalecer en la visión del peruano de hoy es, sobre todo, el conflicto y el contraste entre su predomínio demográfico y su servindumbre - no solo inferioridad - social y económica. La presencia de tres a cuatro millones de hombres de la raza autóctona em el panorama mental de un pueblo de cinco millones, no debe sorprender a nadie en una época en que este pueblo siente la necesidad de encontrar el equilíbrio que hasta ahora le ha faltado en su historia. (MARIATEGUI, [1928], 1958, p. 290)

De acordo com o crítico peruano, os óleos e as xilogravuras presentes nessa exposição são essencialmente construídos sobre bases de forte "plasticidade" e de grande força pictórica, o que não impede que o valor dos conceitos, ou seja, o conteúdo das obras, exerça sua função. Podemos observar que as imagens são construídas a partir de elementos que se valem das formas clássicas de composição, como os planos divididos em duas retas principais, uma horizontal e outra vertical, bem como a perspectiva centralizada, presente também nos retratos. Apesar do cunho realístico, a expressividade é um dado recorrente nas seis imagens apresentadas (em anexo), como podemos observar principalmente no quadro Amauta. Nesta imagem, o semblante do índio é

122 MARIÁTEGUI, José Carlos. "La obra de Jose Sabogal". In: El artista y la Epoca, 14 ed. Lima: Biblioteca Amauta, 1990, p. 90.

${ }^{123}$ MARIATEGUI, José Carlos. Siete Ensayos de Interpretacion de la Realidad Peruana, p. 286. 
fortemente ressaltado, em suas marcas e irregularidades, através do contraste e das variações entre a presença e ausência de luz. Esse contraste de luminosidade parece participar de toda a imagem, que por meio de gradações, entre o fundo escurecido e as manchas luminosas da roupa, faz emergir o rosto deste homem, cujo olhar fixo e profundo nos leva a inquirir sobre a subjetividade psicológica presente na figura.

Em relação ainda à exposição de Buenos Aires, percebe-se o quanto a participação do artista nesta exposição e o esperado "triunfo" de suas obras eram acompanhados pelos "colaboradores" da revista:

(...) Como siempre, como nunca, ha estado usted presente en Amauta, en estos días en que ha mostrado usted sus cuadros a Buenos Aires. Amauta se siente suya, Sabogal, en la misma medida en que usted pertence a Amauta. (Revista Amauta, $\mathrm{n}^{\circ} 18$, out. 1928, p. 93)

Sabogal era assim considerado o "gênio artístico peruano" devido à beleza alcançada em suas obras, obtida, por sua vez, através do apuro técnico e dos recursos expressivos empregados pelo artista. Muitas foram as colaborações de Sabogal à revista Amauta, e em suas páginas pode-se encontrar uma variedade de desenhos, pinturas a óleo, gravuras e até mesmo alguns frisos realizados pelo artista. Manifesta-se a heterogeneidade de seus recursos técnicos, que variam de imagens mais realistas ao uso de esquemas e formas mais geometrizadas e perspectiva chapada - como no friso incaico Las Aclas -, e até certas "deformidades" expressivas, através da redução das linhas e formas - como em Los "mates" y el yaravi (anexo). Assim, Sabogal

(...) há colgado en todas las chozas de los indios un lienzo de esperanza. Los ha impresionado la emoción y como las ventanas al paisaje, los ha entregado el quadro hecho. Representa la emoción dolorosa del índio en su mejor realizacion de belleza. $Y$ ahí nuestra coincidência. El dolor del índio deviene belleza artista en Sabogal y patriotismo político y belegerante en nosostros. (Amauta, no 19, nov. 1928)

Por meio da dualidade entre "raça" e "espírito" chega-se às concepções de Mariátegui sobre a importância de cada época e sociedade criar os seus mitos. 
Esta percepção surge na obra do crítico peruano como contraponto e reflexão sobre a crise mundial, percepção cujas bases estão pautadas na crítica sobre o positivismo no qual se ergueu a civilização burguesa. Segundo suas palavras:

La Razón ha extirpado del alma de la civilización burguesa los residuos de sus antiguos mitos. El hombre occidental ha colocado, durante algún tiempo, en el retablo de los dioses muertos, a la Razón y a la Ciencia. Pero ni la Razón ni la Ciencia pueden ser un mito. Ni la Razón ni la Ciencia pueden satisfacer toda la necesidad de infinito que hay en el hombre. La propia Razón se ha encargado de demosntrar a los hombres que ella no les basta. Que únicamente el Mito poseé la preciosa virtud de llenar su yo profundo. (MARIÁTEGUI, Amauta, 1930, n. 31, p. 01)

Para o crítico peruano o que move o homem na história é a sua capacidade de criar mitos, pois sem o mito a existência humana torna-se vazia de sentido. Por isso quando se menciona o declínio da civilização moderna, Mariátegui volta-se principalmente ao ceticismo no qual a civilização européia caiu em decorrência da guerra. A antítese do ceticismo gerado nesta sociedade seria a "vontade de crer", analisada por ele através da poesia e da filosofia. Tomando o segundo exemplo, em que se utiliza da linguagem filosófica contra os preceitos positivistas, cita uma teoria designada como a teoria do "Mito e da Ação", segundo a qual não existem "verdades absolutas", mas sim "verdades relativas" que se instauram em cada época. No entanto, como tornar esta idéia, a de que "a verdade de hoje não será a mesma da de amanhã" porque "cada sociedade constrói sua própria época", inteligível ao vulgo ${ }^{124}$ Estas indagações, presentes nas preocupações de Mariátegui sobre "onde encontrar o mito capaz de reanimar espiritualmente a ordem em declínio", revelam-se através da reflexão sobre a práxis diante dos procedimentos históricos:

La pregunta exaspera la anarquía intelectual, la anarquía espiritual de la civilización burguesa. Algunas almas pugnan por restaurar el medio Evo y el ideal católico. Otras trabajan por un retorno al Renacimiento y al ideal clásico. El fascismo por boca de sus teóricos, se atribuye una mentalidad medioeval y católica; cree representar el espíritu de la Contra-Reforma,

\footnotetext{
${ }^{124}$ MARIÁTEGUI, José Carlos. "El hombre y el Mito", In: José Carlos Mariátegui: La emoción de nuestro tiempo. Lima: Revista Amauta, $n^{\circ} 31$, junio-julio, 1930, p. 02-03.
} 
aunque por otra parte, pretende encarnar la idea de la Nación, idea típicamente liberal. (MARIÁTEGUI, Amauta,1930, n. 31, p. 03)

A partir dessas afirmações poderíamos dizer que para Mariátegui, tanto na arte, como na filosofia, a linguagem empregada seria a responsável por expressar essa "verdade relativa" de modo acessível às classes populares, e por meio dela poder-se-ia reanimar o eu profundo e devolver a "vontade de crer" do povo, na possibilidade de construção dos seus mitos e história. Esta teoria, vista sob a perspectiva político-econômica, divide a sociedade em classes sociais, e distingue a burguesia do proletariado por intermédio da capacidade deste em construir seus mitos. No caso, a crise que atravessa a burguesia faz com que ela já não seja capaz de gerar seus mitos, enquanto para o proletariado o mito irá ainda realizarse com a revolução social ${ }^{125}$.

La burguesía no tiene ya mito ninguno. Se ha vuelto incrédula, escéptica, nihilista. El mito liberal renacentista, ha envejecido demasiado. El proletariado tiene un mito: la revolución social. Hacia ese mito se mueve con una fé vehemente y activa. La burguesía niega; el proletariado afirma. La inteligencia burguesa se entretiene en una crítica racionalista del método, de la teoría, de la técnica de los revolucionarios. !Qué incomprensión! La fuerza de los revolucionarios no está en su ciencia; está en su fé, en su pasión, en su voluntad. Es una fuerza religiosa, mística, espiritual. Es la fuerza del Mito. La emoción revolucionaria, como escribí en un artículo sobre Gandhi, es una emoción religiosa. Los motivos religiosos se han desplazado del cielo a la tierra. No son divinos; son humanos, son sociales. (MARIÁTEGUI, Amauta, 1930, n. 31, p. 03)

A capacidade de representar de maneira profunda a alma indígena, e a partir dela ressignificar a própria tradição peruana, é o que faz da obra de Sabogal um valor-signo aos olhos de Mariátegui. Essa capacidade do pintor está no

125 "Ortega y Gasset habla del "alma desencantada". Romain Rolland habla del "alma desencantada". ?Cuál de los dos tiene razón? Ambas almas coexisten. El "alma desencantada" de Ortega y Gasset es el alma de la decadente civilización burguesa. El "alma encantada" de Romain Rolland es el alma de los forjadores de la nueva civilización . Ortega y Gasset no vé sino el ocaso, el tramonto, der Untergang. Romain Rolland vé el orto, el alba, der Aufgang". Ibidem, p. 03. 
processo "biológico, espontâneo e ordenado" que o crítico identifica entre a vida do artista e sua obra.

Sabogal pinta sin la preocupacíón de la tesis. La pintura en sí misma le basta. Su obra es puramente plástica, pictórica. Pero esto no impide que, por cierta íntima asonancia con sentimentos y reinvindicaciones de la época, trascienda e influya poderosamente en la vida actual del Perú. El pintor piensa y sueña en imágenes plásticas. (MARIÁTEGUI, [1928], 1990, p. 91)

Desta constatação, em que José Sabogal cria formas que visam ser a expressão de um sentimento do artista aliado à sua técnica, chega-se também, ao mesmo tempo, ao conteúdo da obra: "Las imagenes engendran conceptos, lo mismo que los conceptos inspiram imagines." Tais imagens condensam a expressão culminante do movimento espiritual de um povo, sua transcendência ideológica, o que faz para Mariátegui que as obras de Sabogal sejam a obra de um construtor, do amanhecer de um novo povo ${ }^{126}$.

Vale lembrar que tanto Mariátegui como Sabogal participaram do movimento lançado na revista Amauta chamado Ressurgimiento, que propunha a nova cruzada Pró-Indígena.

El proceso de gestación del Grupo viene de más lejos. Se confunde con el del movimento espiritual e ideológico suscitado por los que, partiendo de afines principios o comunes sentimientos, piensan, como ya una vez he dicho, que 'el progreso del Perú será fictício, o por lo menos no será peruano, mientras no constituya la obra y no represente el bienestar de la masa peruana, que en cuarto quintas partes es indígena y campesina'. Este movimiento anuncia y prepara una profunda tranformación nacional. (MARIÁTEGUI, Amauta, 1927)

Assim, o nacionalismo para Mário de Andrade e José Carlos Mariátegui tornou-se o motivo pelo qual os dois autores visaram compreender e resgatar através da valorização e formação do povo brasileiro e peruano - uma cultura que

${ }^{126}$ MARIÁTEGUI. "La obra de Jose Sabogal". In: El artista y la Epoca, 14 ed. Lima: Biblioteca Amauta, 1990, p. 91. 
partisse das bases populares, para que atingisse sua própria expressão. Este desejo pode ser entendido dentro de seus projetos estéticos e ideológicos, em que através do qual verificamos que o procedimento técnico da linguagem, junto a seus valores históricos, quando estabelecidos de maneira recíproca, tornam-se responsáveis pelo caráter revolucionário da expressão artítica. 


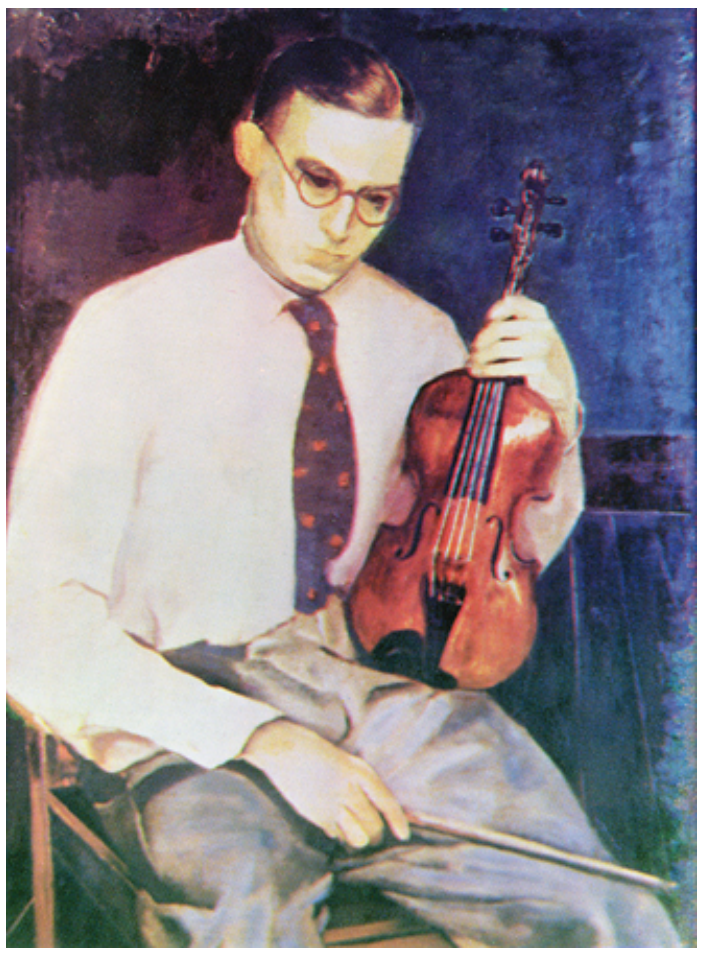

Figura 1: PORTINARI, Candido. Retrato de Oscar Borghert. 1931. 1 original de arte, óleo sobre tela; $110 \times 80 \mathrm{~cm}$. Coleção Particular.

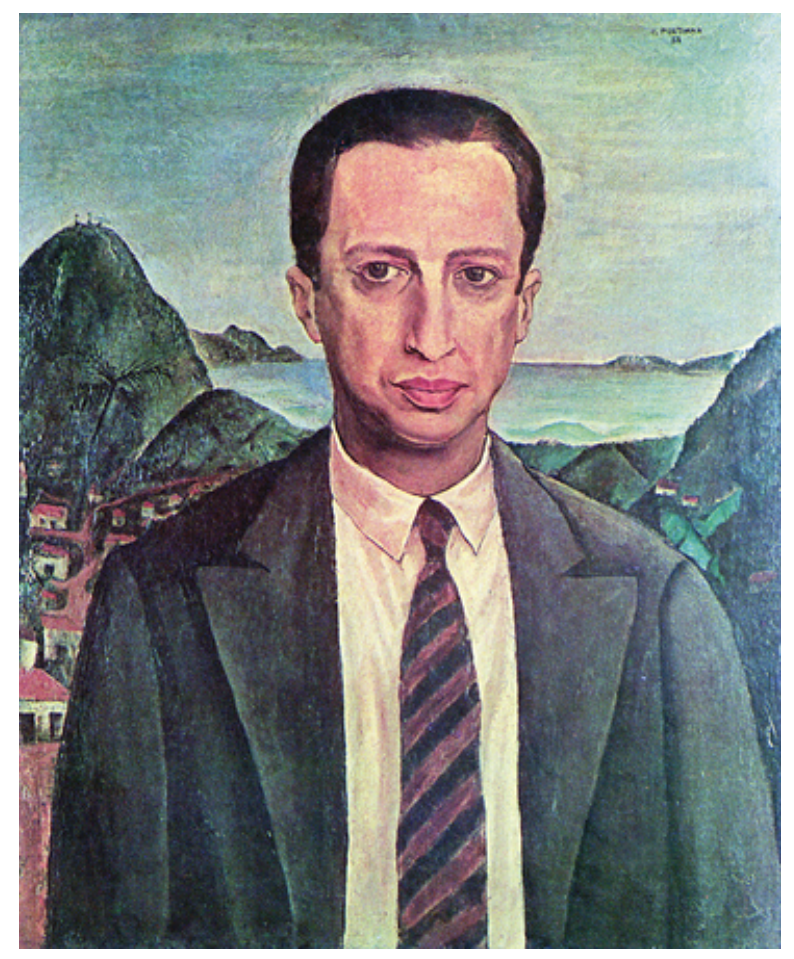

Figura 2: PORTINARI. Candido. Retrato de Manuel Bandeira. 1931. 1 original de arte, óleo sobre tela; $73 \times 60 \mathrm{~cm}$. Coleção Particular. 


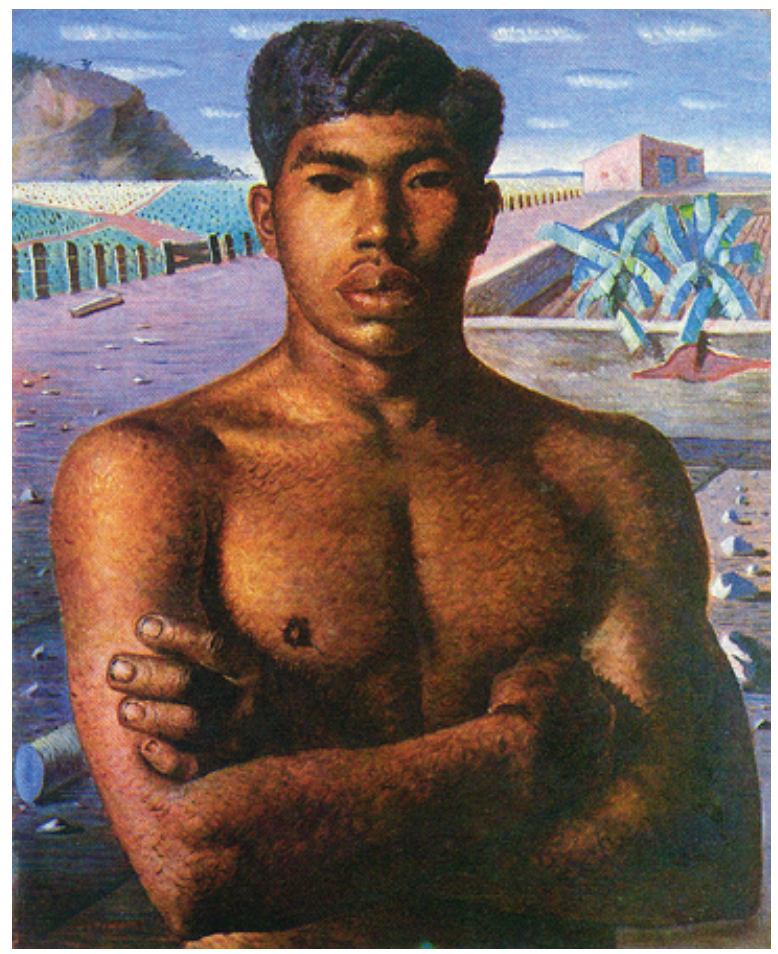

Figura 3: PORTINARI, Candido. Mestiço. 1934. 1 original de arte, óleo sobre tela; 81 x 65 cm. Pinacoteca do Estado (São Paulo, SP).

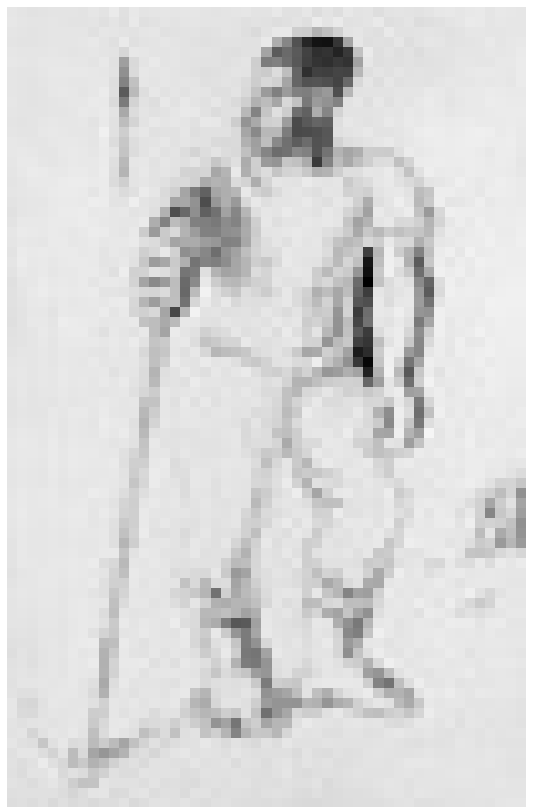

Figura 4: PORTINARI, Candido. Preto da Enxada. 1934. 1 original de arte, desenho a nanquim bico-de-pena e naquim pincel/papel; 40,3 x 26 cm (aproximadas). Coleção particular, Rio de Janeiro, RJ. 


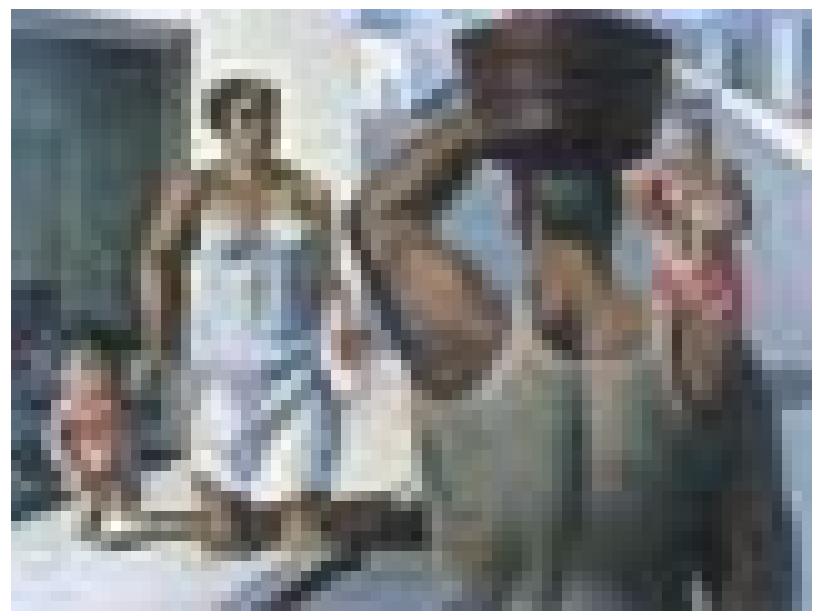

Figura 5: PORTINARI, Candido. Sorveteiro. 1934. Pintura a óleo sobre tela; 44 x $59 \mathrm{~cm}$. Coleção desconhecida, Rio de Janeiro, RJ.

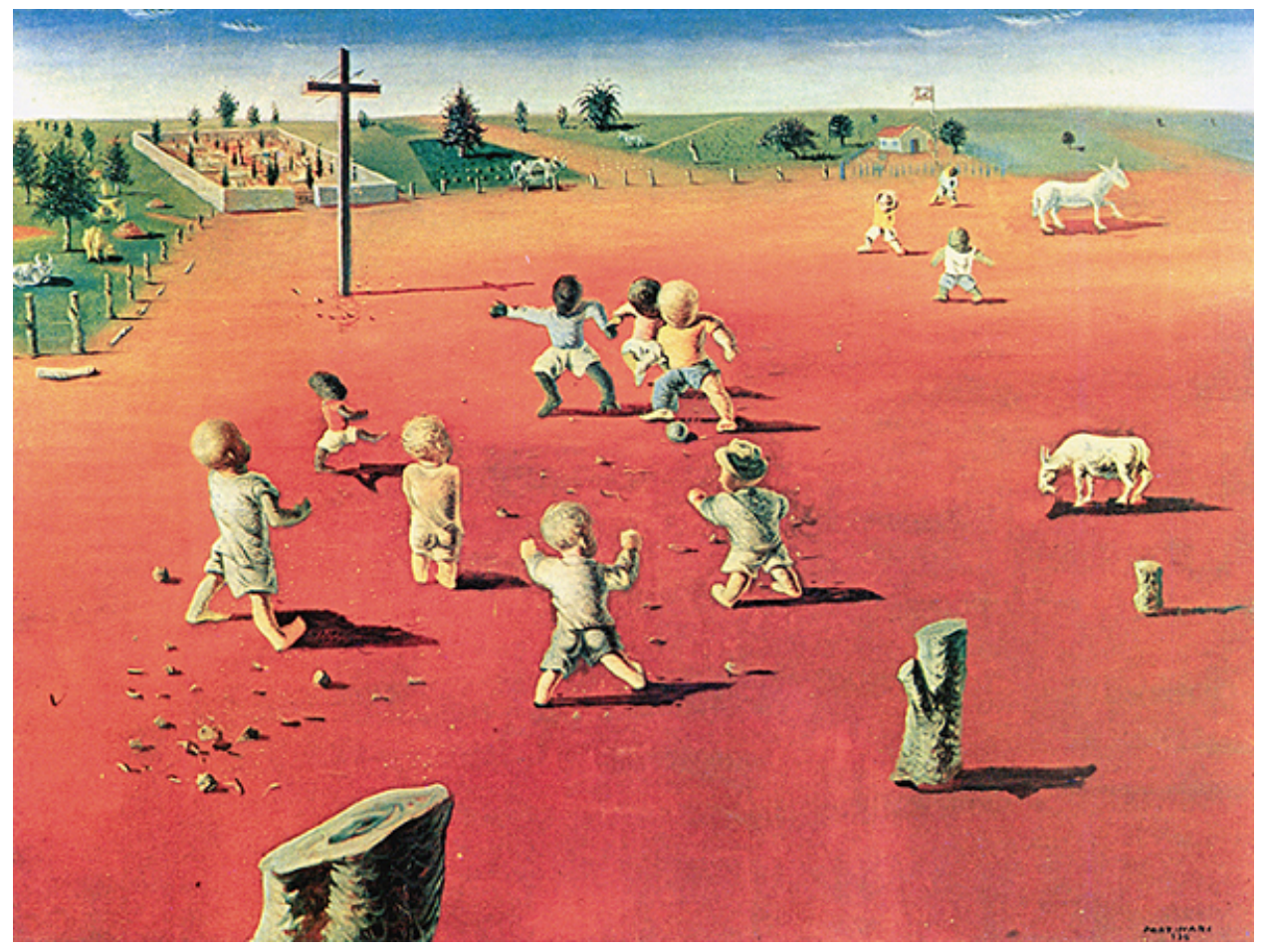

Figura 6: PORTNARI, Candido. Futebol. 1935. 1 original de arte, óleo sobre tela; 97 X $130 \mathrm{~cm}$. Coleção particular. 


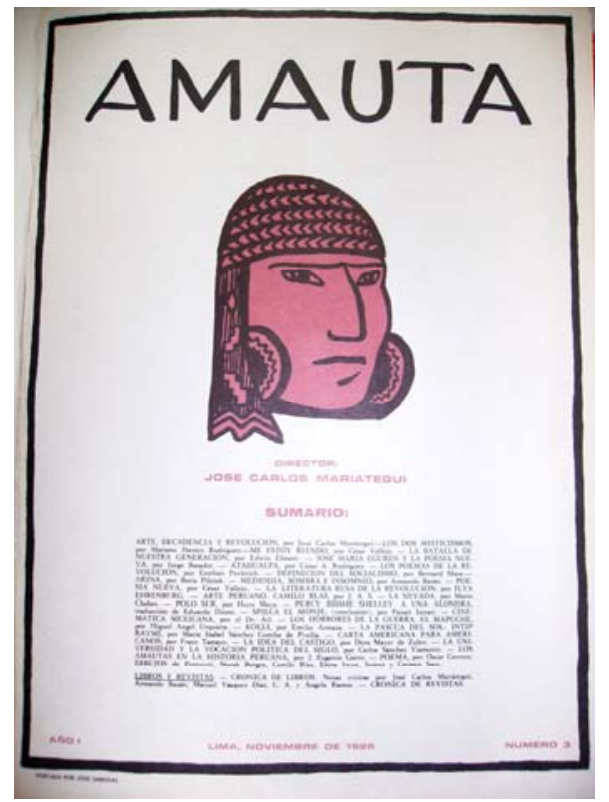

Figura 1: SABOGAL, José. Ilustração p/ capa Revista Amauta. Año I, nº 3. Lima: Editora Amauta; noviembre de 1926.

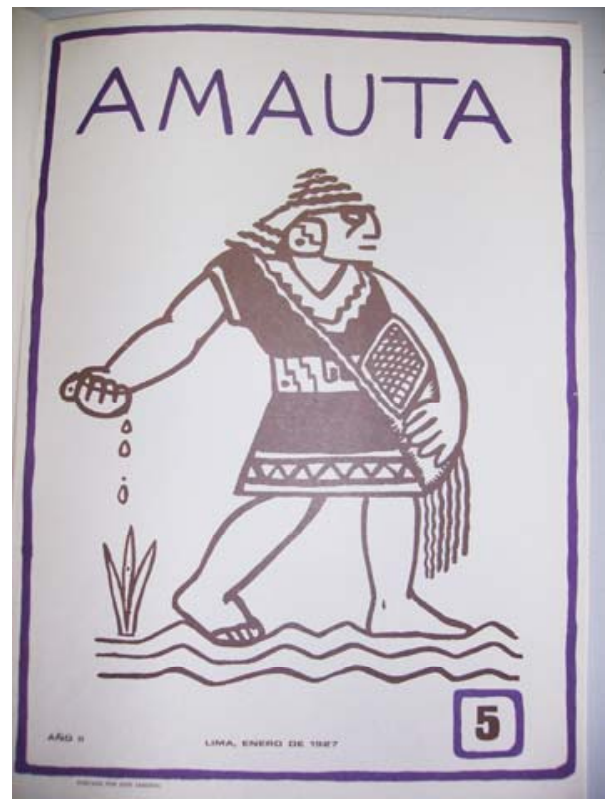

Figura 2: SABOGAL, José. Ilustrações p/ capa Revista Amauta. Año II, nº 5. Lima: Editora Amauta; enero de 1927. 


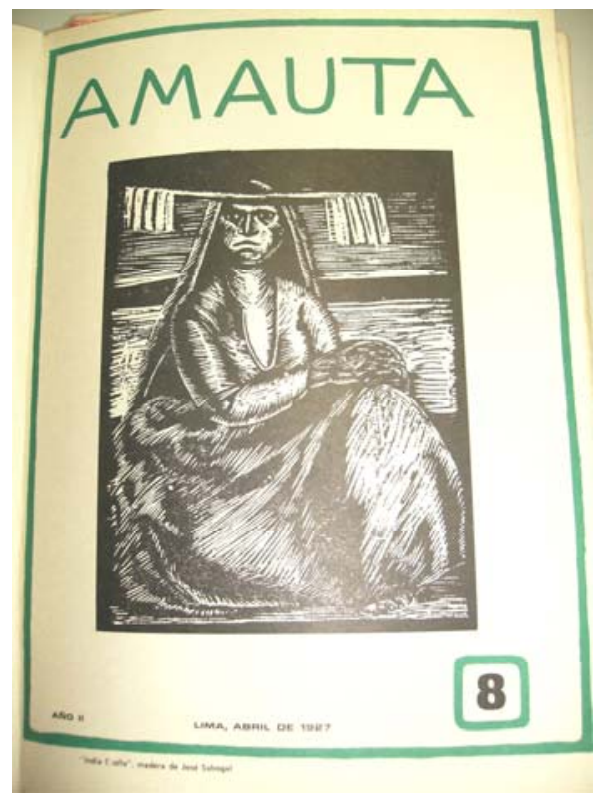

Figura 3: SABOGAL, José. "Ìndia Ciolla". Ilustração p/ capa Revista Amauta. Año II, nº 8. Lima: Editora Amauta; abril de 1927.

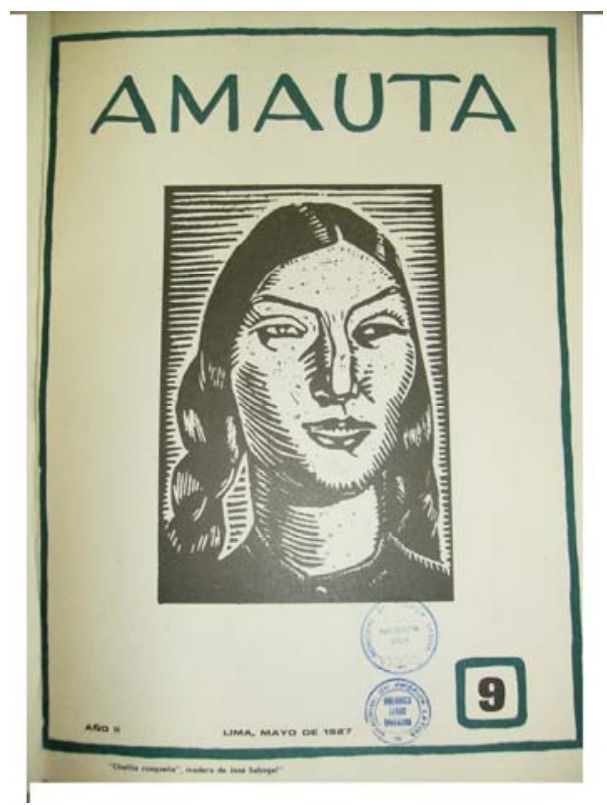

Figura 4: SABOGAL, José. "Cholita cusqueña". Ilustração p/ capa Revista Amauta. Año II, n 9. Lima: Editora Amauta; mayo de 1927. 


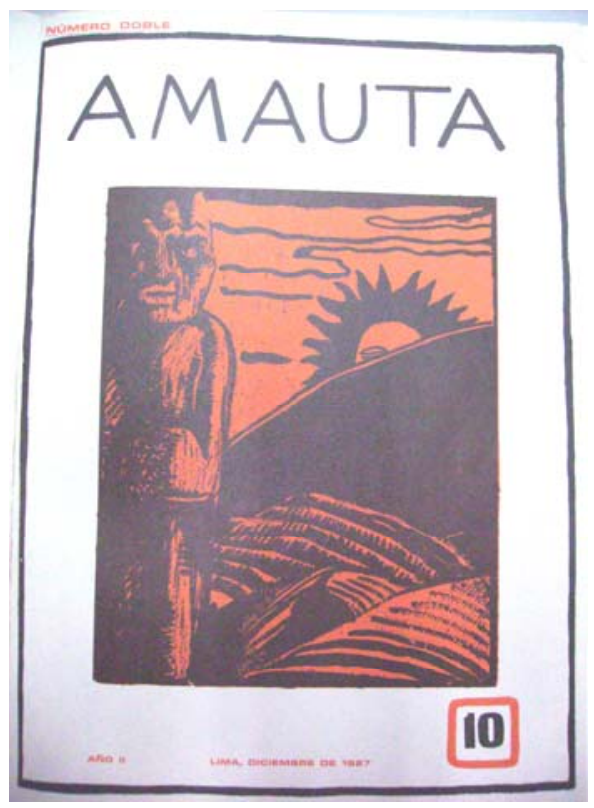

Figura 5: SABOGAL, José. Ilustração p/ capa Revista Amauta. Año II, nº 10. Lima: Editora Amauta; diciembre de 1927.

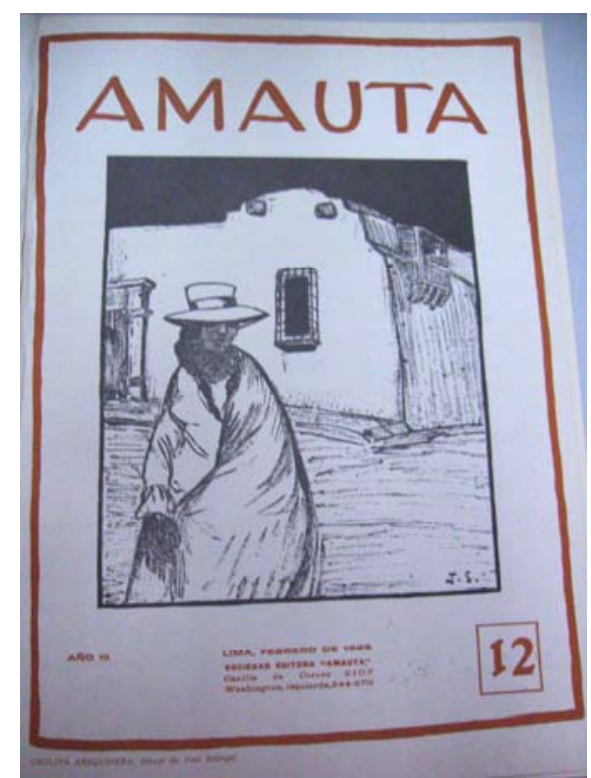

Figura 6: SABOGAL, José. "Cholita Arequipeña". Ilustração p/ capa Revista Amauta. Año III, nº 12. Lima: Editora Amauta; febrero de 1928. 


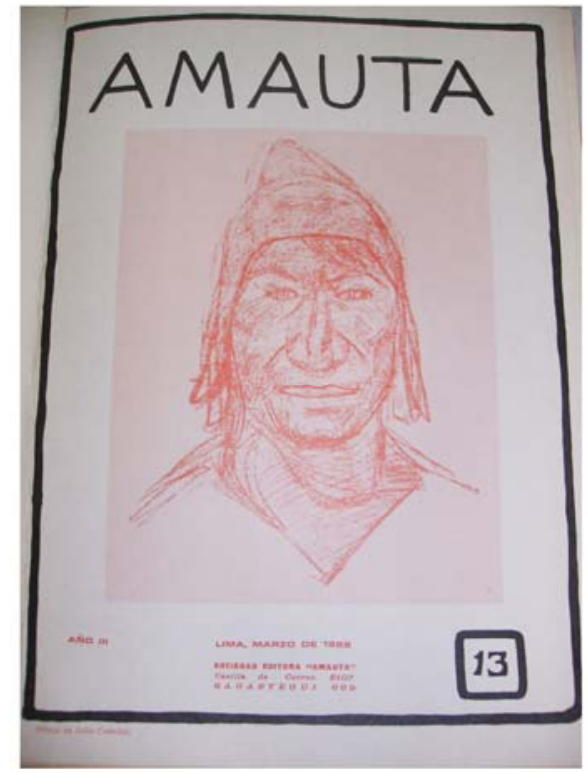

Figura 7: CODESINO, Julia. Ilustração p/ capa Revista Amauta. Año III, no 13. Lima: Editora Amauta; marzo de 1928.

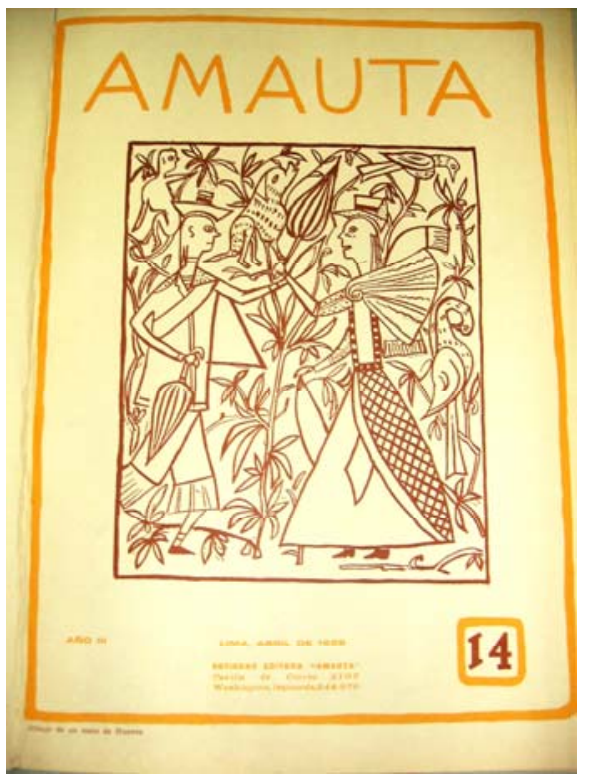

Figura 8: "Mate de Huanta". Ilustração p/ capa Revista Amauta. Año III, nº 14. Lima: Editora Amauta; abril de 1928. 


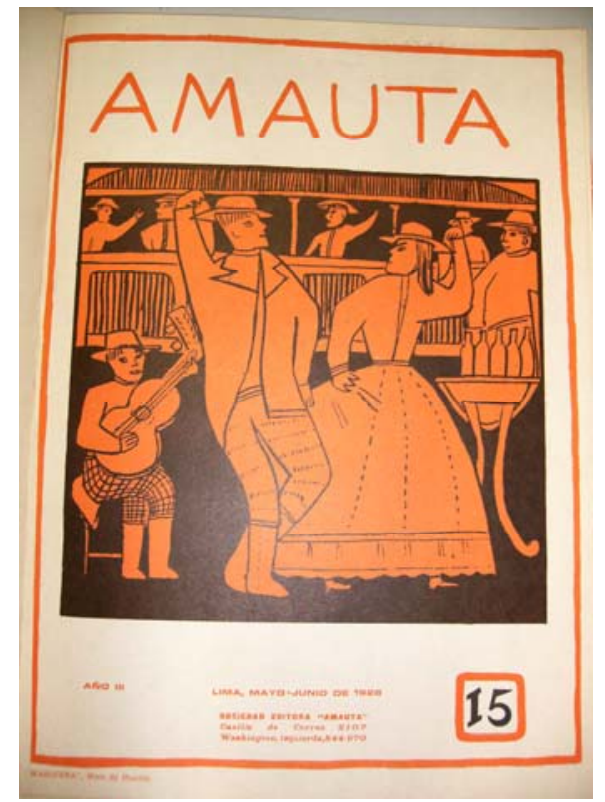

Figura 9: "Marinera". Ilustração p/ capa Revista Amauta. Año III, no 15. Lima: Editora Amauta, mayo- junio de 1928.

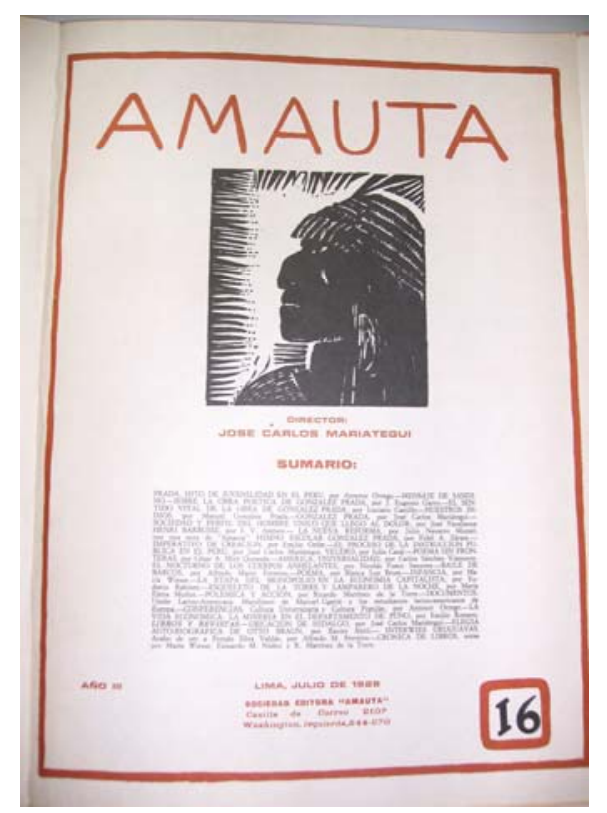

Figura 10: SABOGAL, José. Ilustração p/ capa Revista Amauta. Año III, nº 16. Lima: Editora Amauta; julio de 1928. 


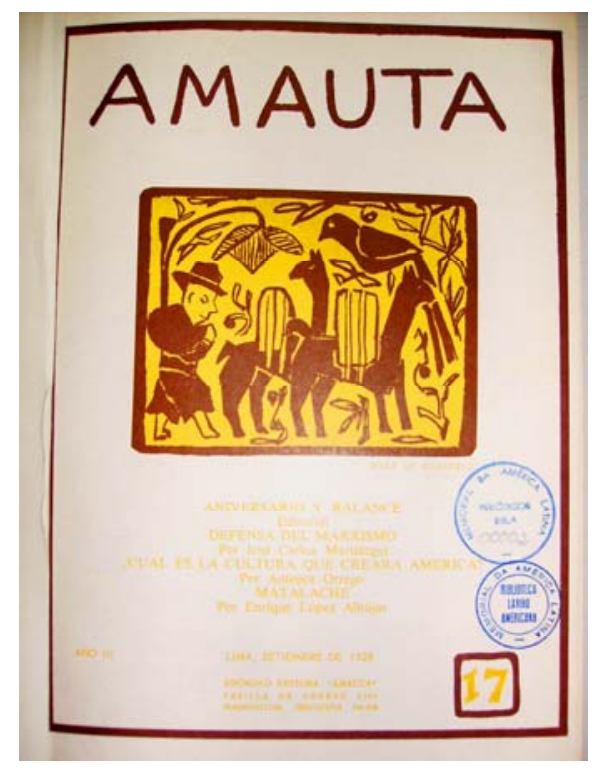

Figura 11: "Mate de Huancayo". Ilustração p/ capa Revista Amauta. Año III, no 17. Lima: Editora Amauta; setiembre de 1928.

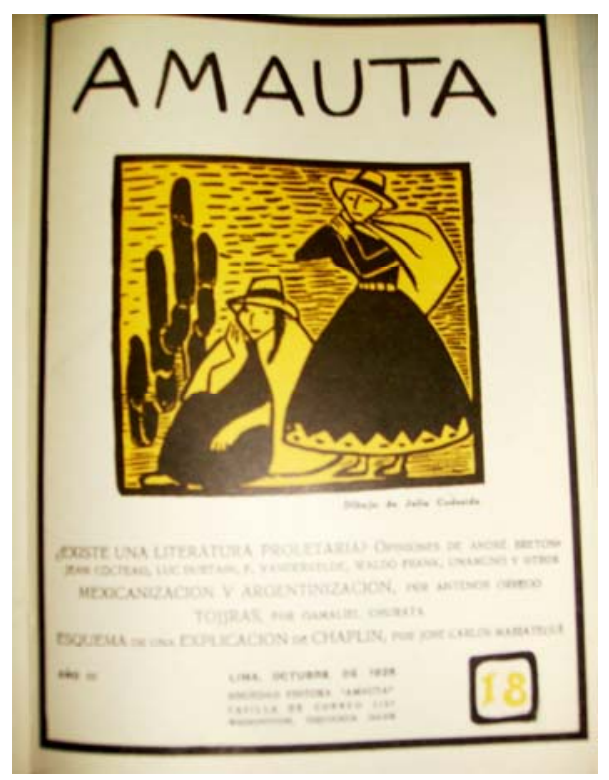

Figura 12: CODESINO, Julia. Ilustração p/ capa Revista Amauta. Año III, no 18. Lima: Editora Amauta, octubre de 1928. 


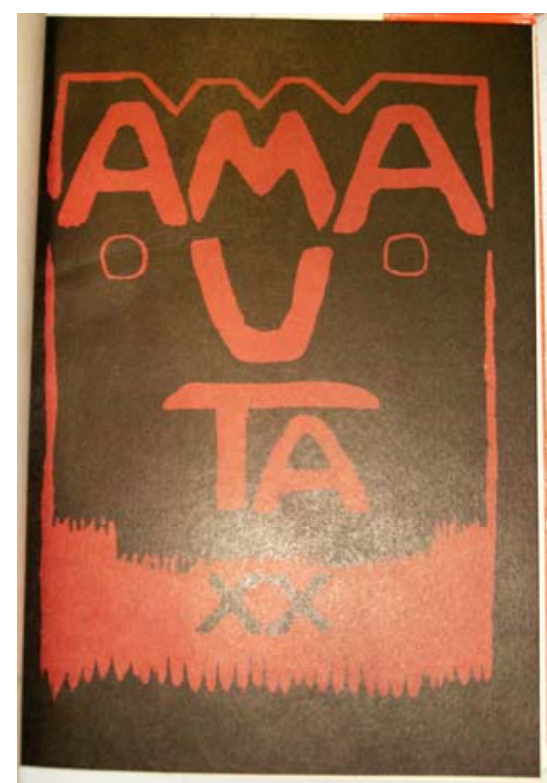

Figura 13: SABOGAL, José. llustração p/ capa Revista Amauta. Año III, n 20. Lima: Editora Amauta, enero de 1929.

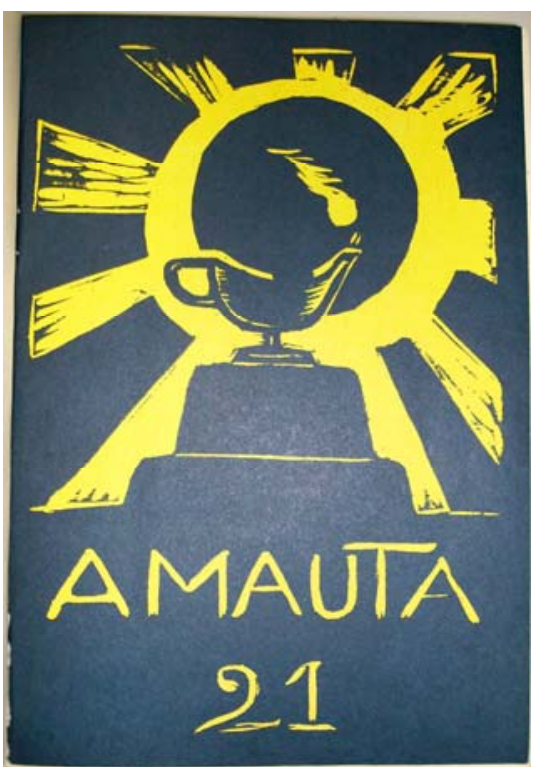

Figura 14: SABOGAL, José. Ilustração p/ capa Revista Amauta, $n^{\circ}$ 21. Lima: Editora Amauta, feb.-mar. de 1929. 


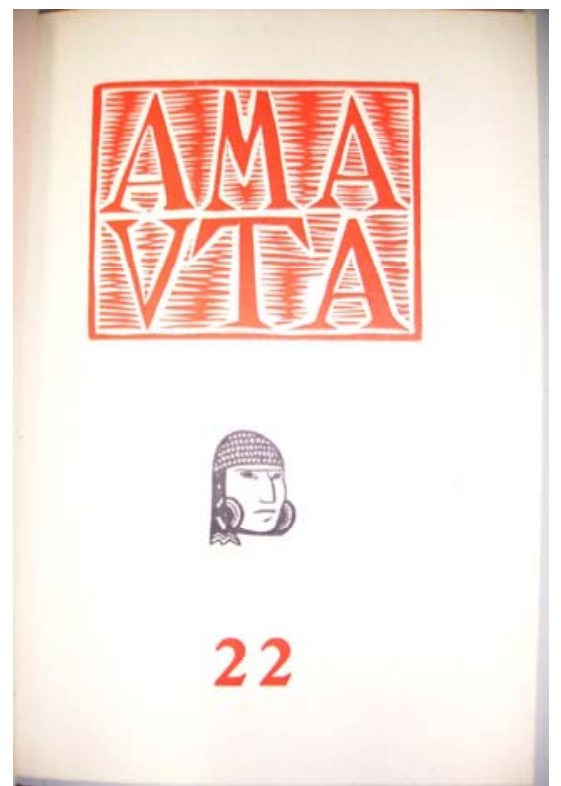

Figura 15: SABOGAL, José. llustração p/ capa Revista Amauta, $n^{\circ}$ 22. Lima: Editora Amauta, abril de 1929.

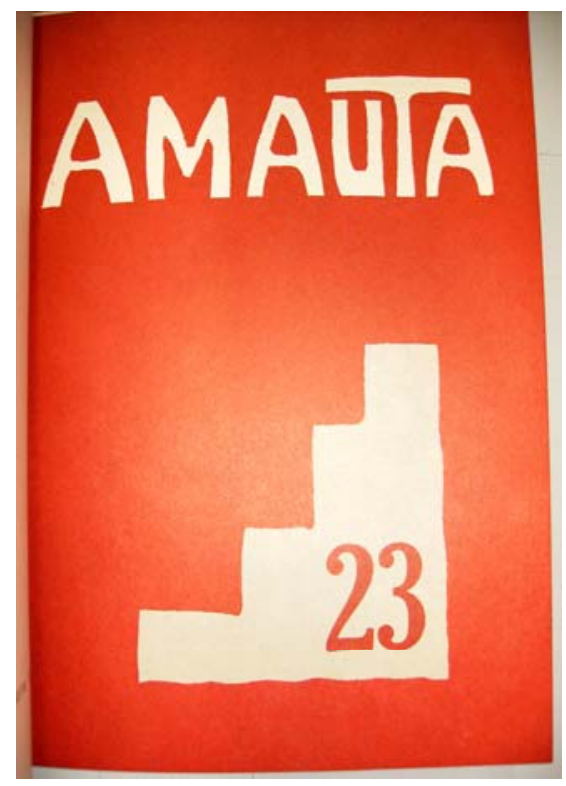

Figura 16: SABOGAL, José. Ilustração p/ capa Revista Amauta, $\mathrm{n}^{\circ}$ 23. Lima: Editora Amauta, mayo de 1929. 


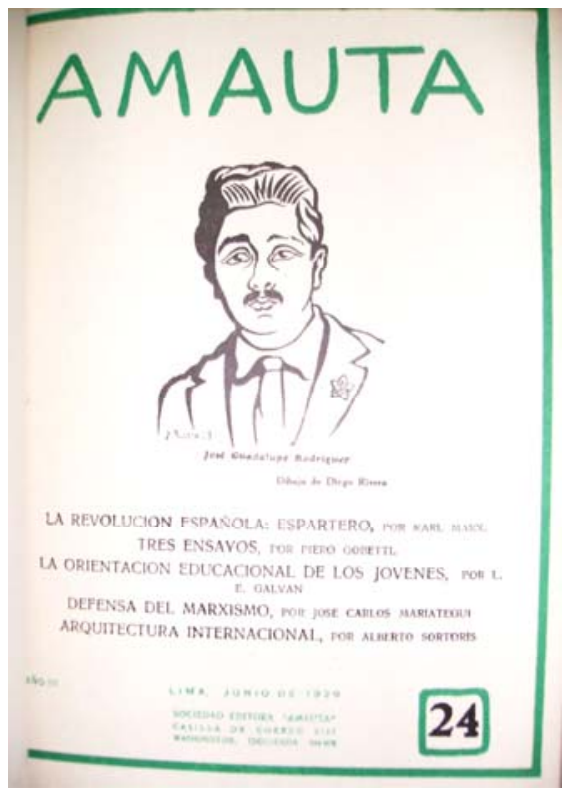

Figura 17: RIVERA, DIEGO. Ilustração p/ capa Revista Amauta. Año III, n n 24. Lima: Editora Amauta; junio de 1929.

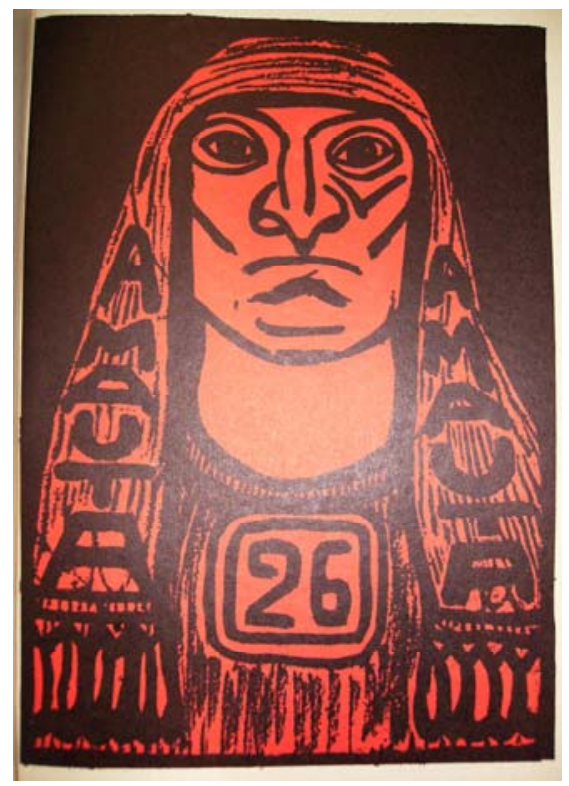

Figura 18: SABOGAL, José. llustração p/ capa Revista Amauta, $n^{\circ}$ 26. Lima: Editora Amauta, set.-out. de 1929. 


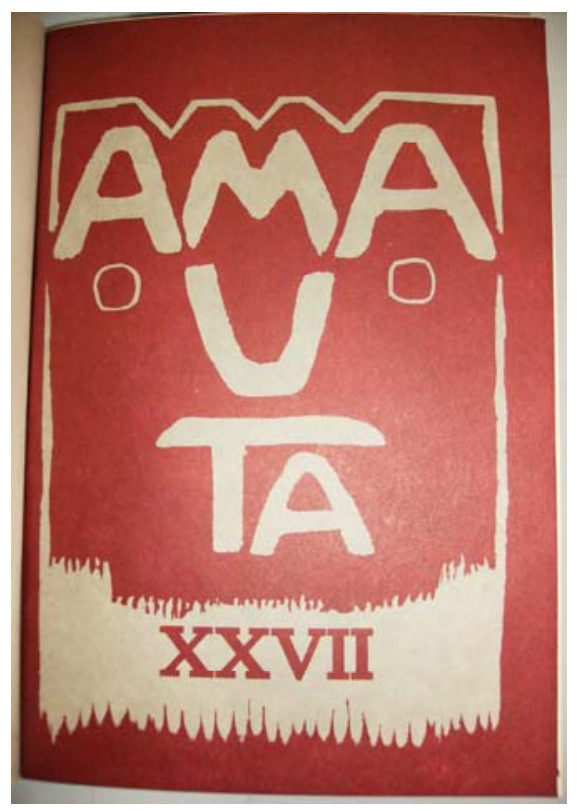

Figura 19: SABOGAL, José. Ilustração p/ capa Revista Amauta, $n^{\circ}$ 27. Lima: Editora Amauta, nov.-dic. de 1929.

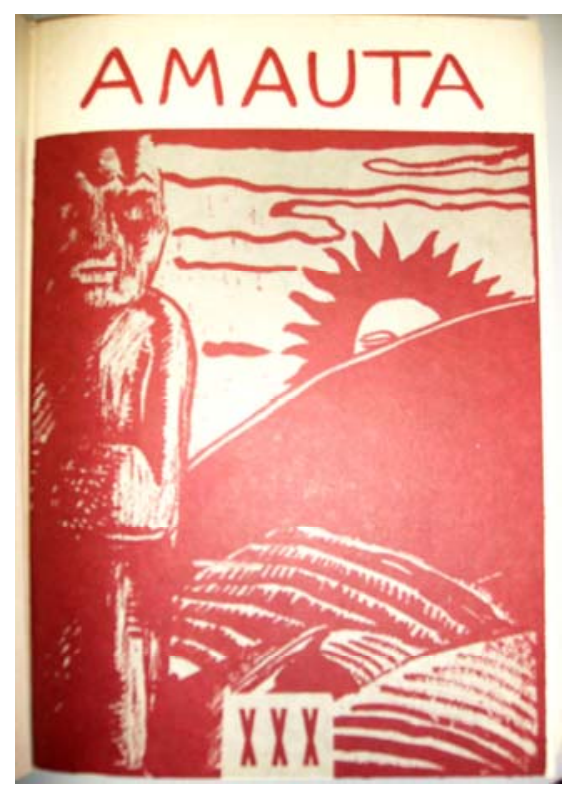

Figura 20: SABOGAL, José. Ilustração p/ capa Revista Amauta, $n^{\circ}$ 30. Lima: Editora Amauta, abril-may de 1930 


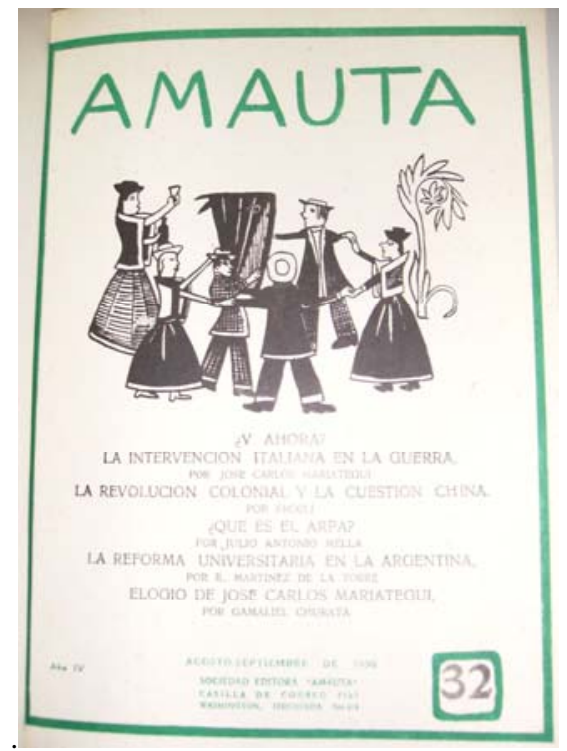

Figura 21: SABOGAL, José. Ilustração p/ capa Revista Amauta. Año IV, nº 32. Lima: Editora Amauta; ago.- set. de 1930.

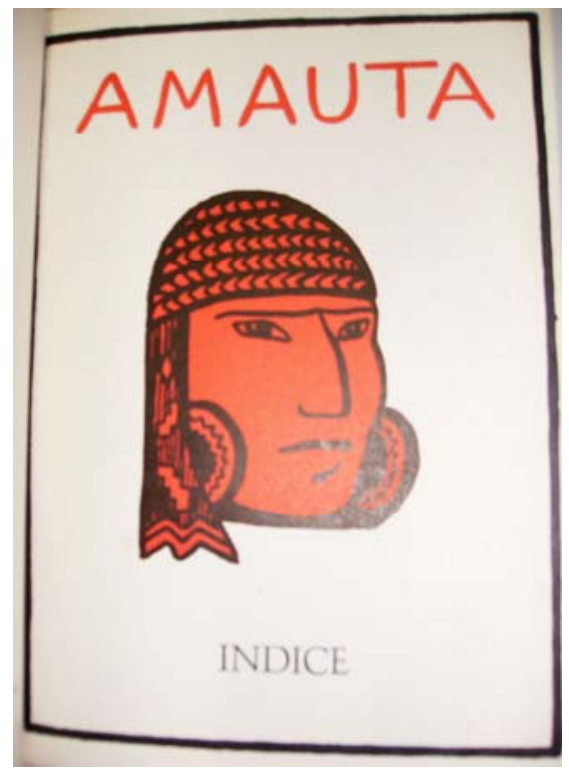

Figura 22: SABOGAL, José. Ilustração p/ capa Revista Amauta. Índice. Lima: Editora Amauta. 


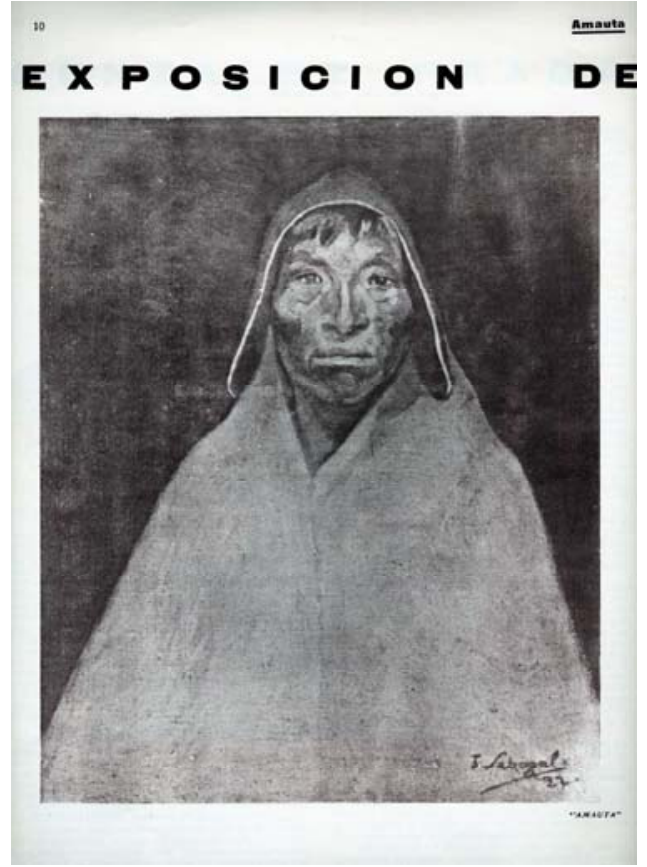

Ilustração 1: SABOGAL, José. Amauta. In: Revista Amauta, Lima: Ed. Amauta, nº 16, 1928, p. 10.

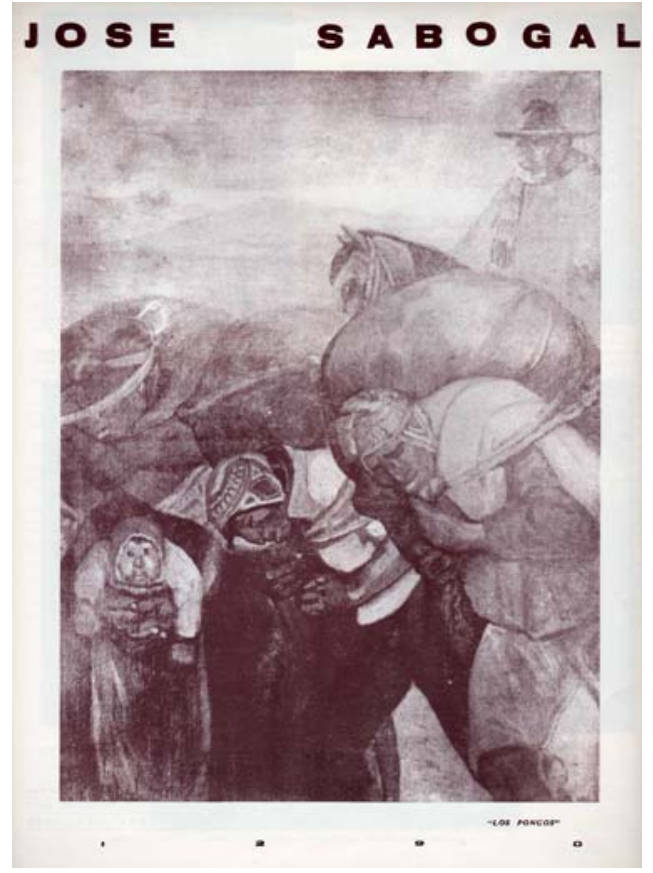

Ilustração 2: SABOGAL, José. Los Pongos. In: Revista Amauta, Lima: Ed. Amauta, nº 16, 1928, p. 11. 


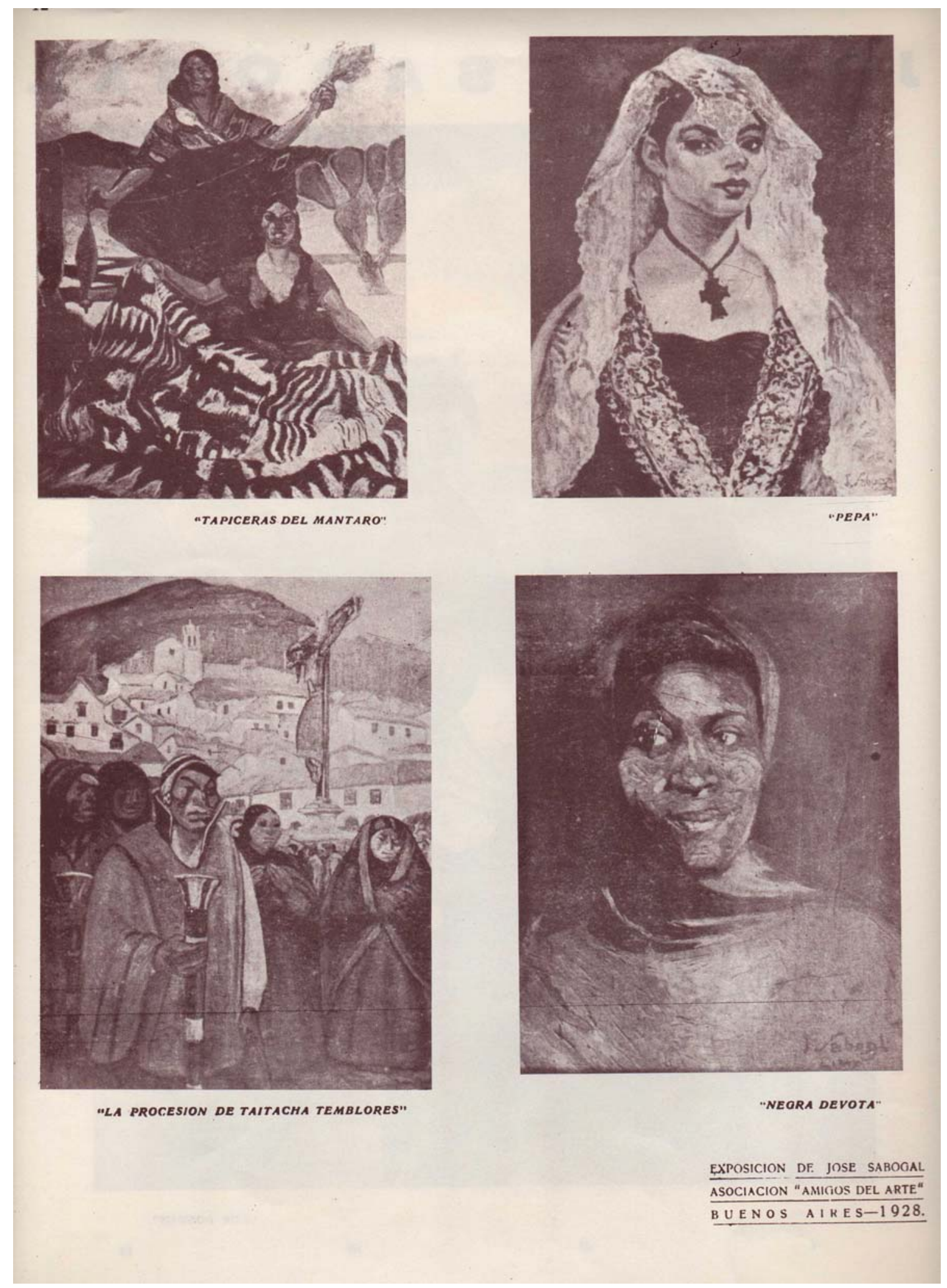

Ilustração 3: SABOGAL, José. "Tapiceras Del Mantaro"; "Pepa”, "La procesionde Taitacha Temblores”, "Negra devota". In: Revista Amauta, Lima: Ed. Amauta, n 16, 1928, p. 12. 


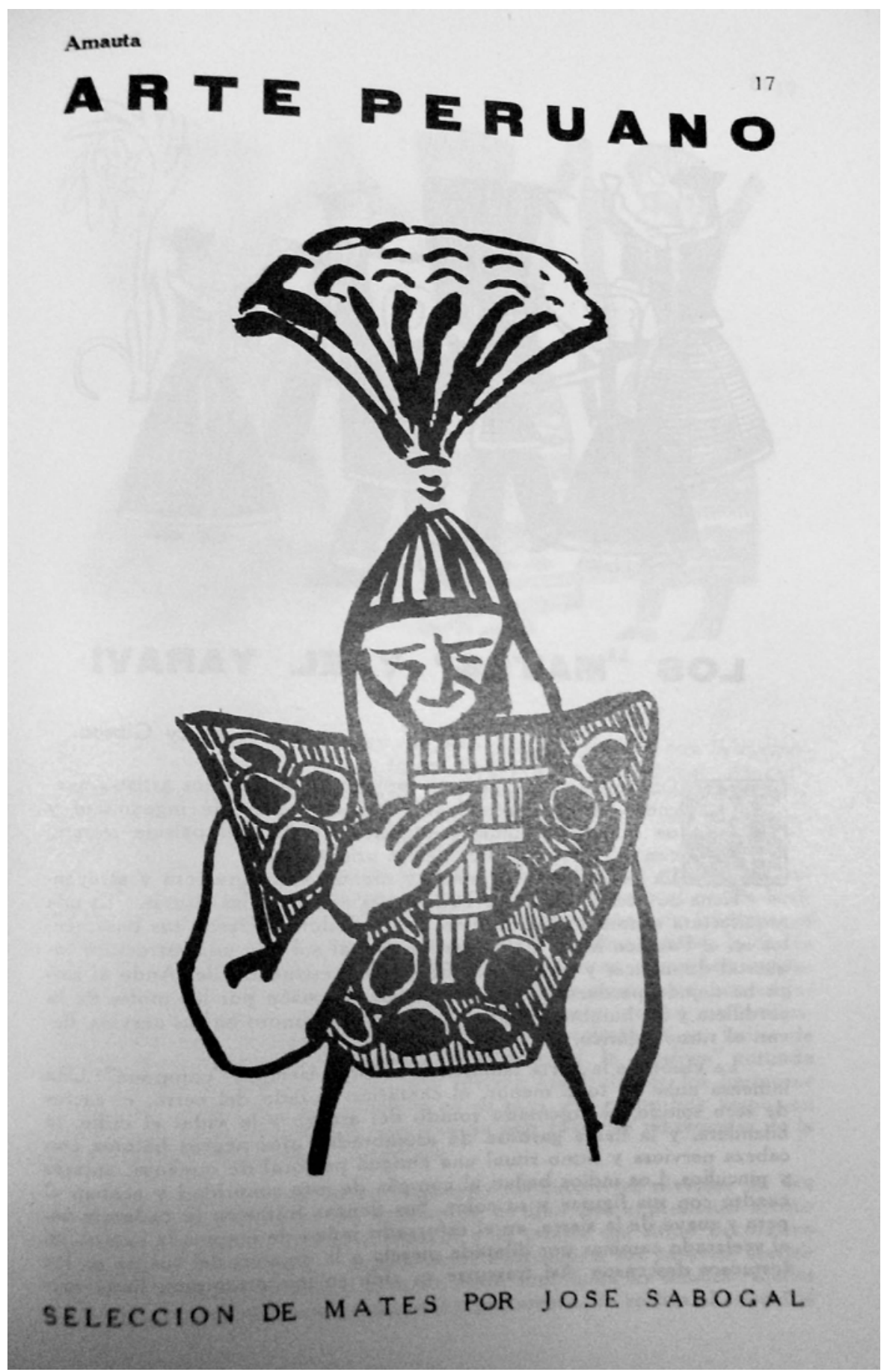

Ilustração 4: SABOGAL, José. Seleción de Mates. In: Revista Amauta, Lima: Ed. Amauta, nº 22, 1929. 


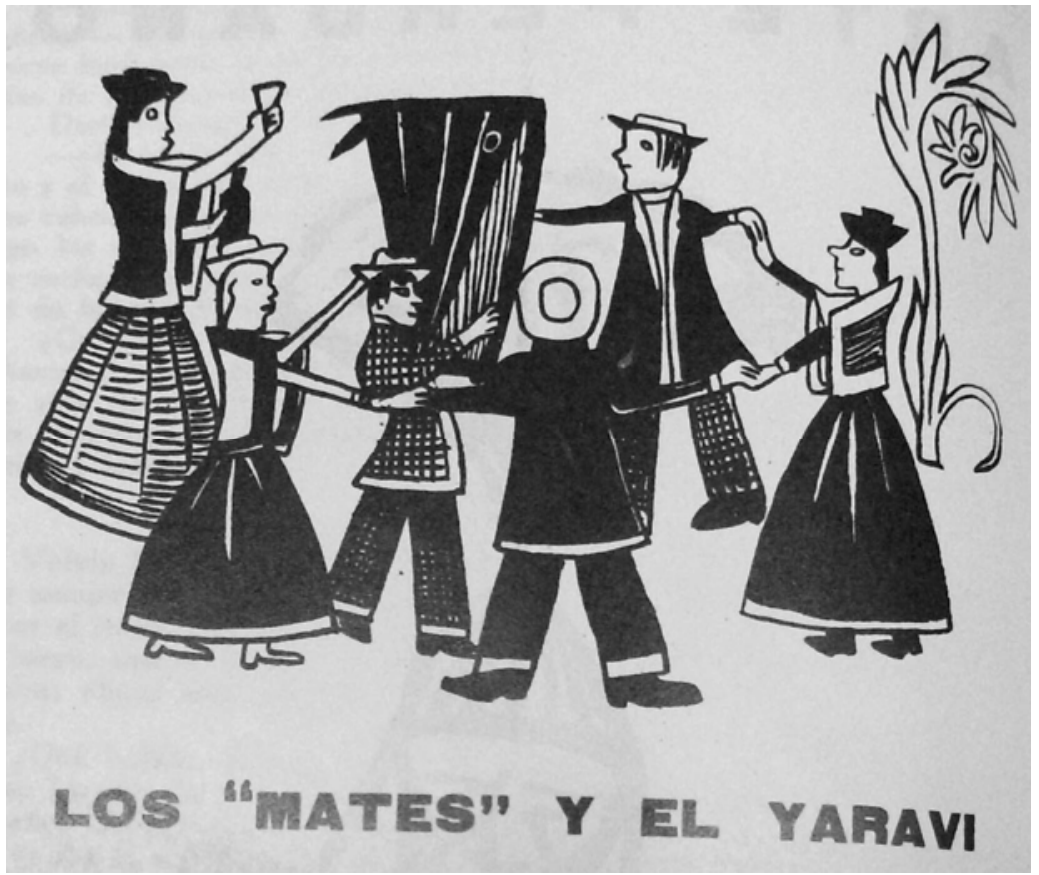

Ilustração 5: SABOGAL, José. Seleción de Mates. In: Revista Amauta, Lima: Ed. Amauta, nº 22, 1929.

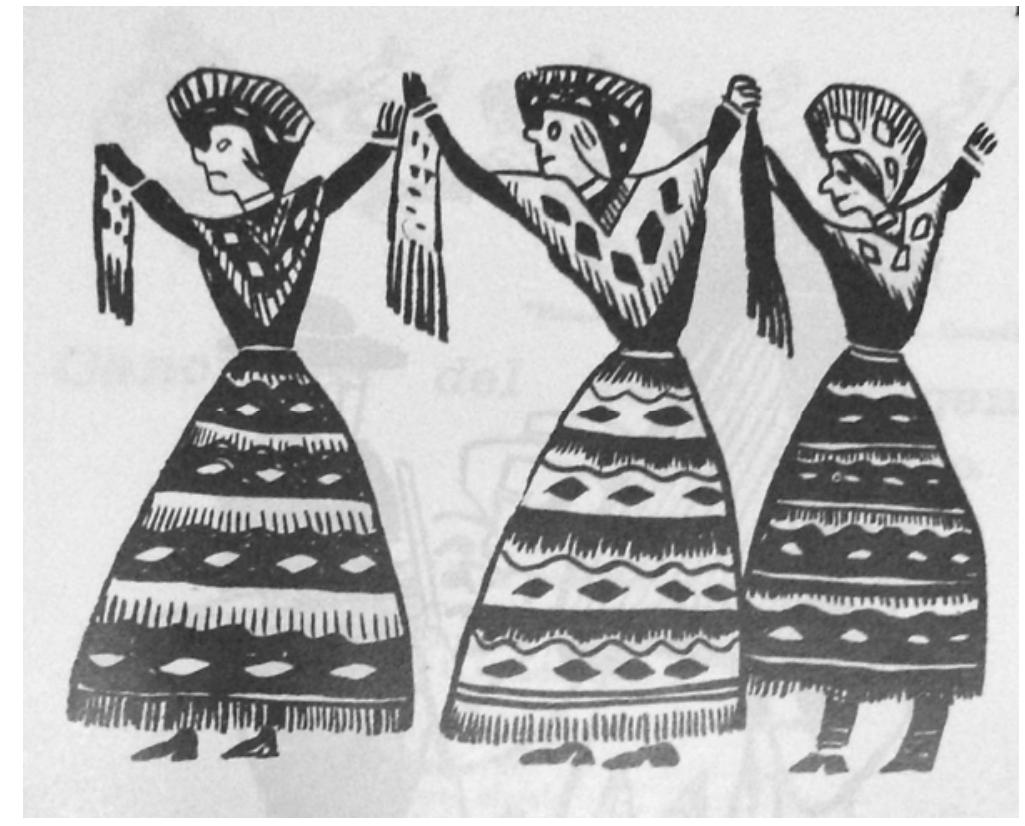

Ilustração 6: SABOGAL, José. Seleción de Mates. In: Revista Amauta, Lima: Ed. Amauta, nº 22, 1929. 


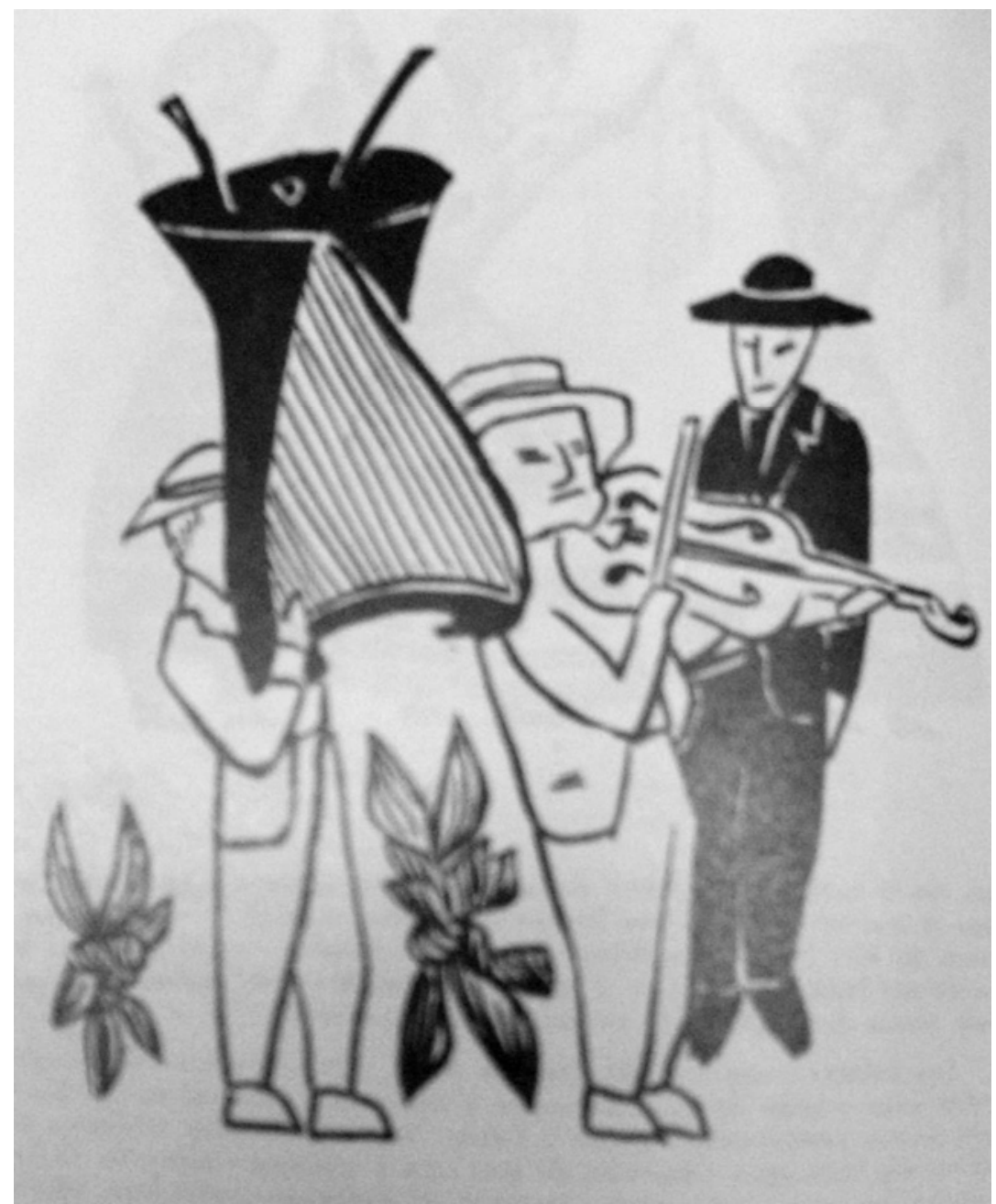

Ilustração 7: SABOGAL, José. Seleción de Mates. In: Revista Amauta, Lima: Ed. Amauta, n² 22, 1929. 


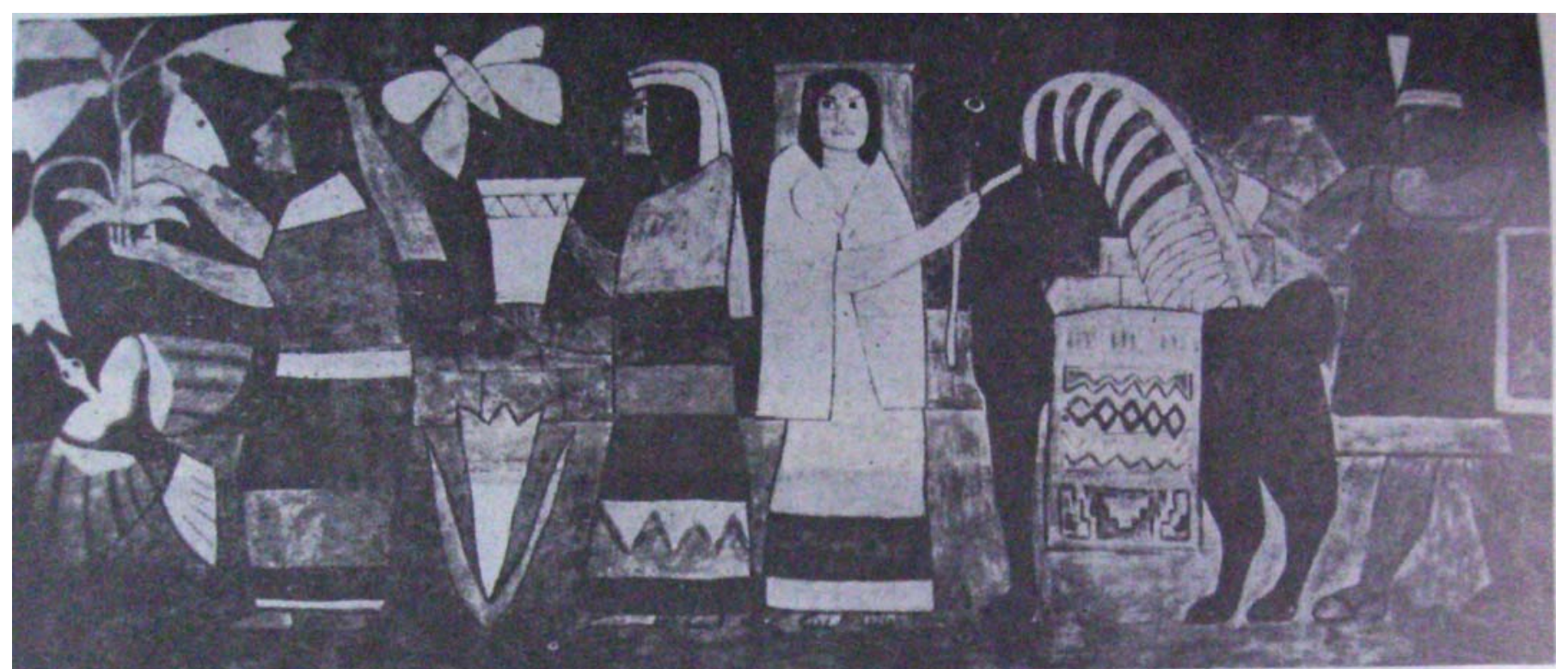

"LAS ACLAS". Friso incaico por José Sabogal. 1929 Ilustração 8: SABOGAL, José. Las Aclas. Friso incaico. In: Revista Amauta: Lima, n 22, 1929, p. 33. 

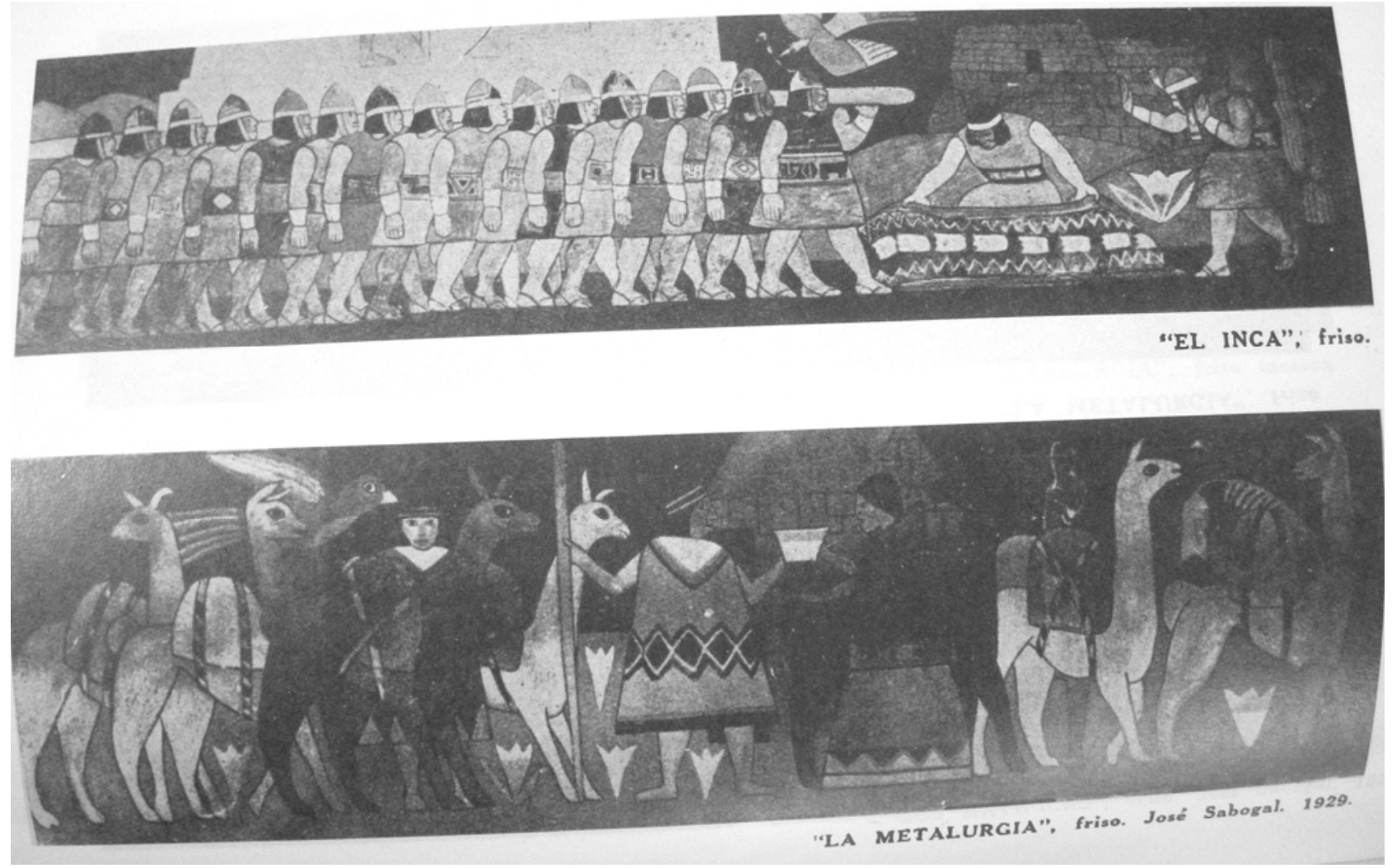

Ilustração 9: SABOGAL, José. "El Inca" e "La Metalurgia”. Frisos incaicos. In: Revista Amauta, Lima: n 22, 1929, p. 34. 


\title{
Capítulo 4 - Arte e expressão artística: considerações finais
}

\begin{abstract}
Si me he detenido largamente en ciertos escritores y ciertos artistas, lo he hecho tal como el dramaturgo elige, entre las palabras de sus personajes, las más saltantes y las más significativas para hacer su pieza. He escogido, he omitido, con la mira de sugerir un vasto movimiento por algunas líneas que puedan asir y retener algo de la solidez de la vida.
\end{abstract}

(Waldo Frank, prólogo Nuestra América, apud. Mariátegui)

\begin{abstract}
Nós, os modernistas de minha geração, sacrificávamos conscientemente, pelo menos alguns, a possível beleza das nossas artes, em proveito de interesses utilitários. A arte se empobrecia de realidades estéticas, dissolvida em pesquisas. Experimentações rítmicas, auscultações do subconsciente, adaptações nacionais de linguagem, de música, de cores e formas plásticas, de crítica - tudo eram interesses que deformavam a isenção e o equilíbrio de qualquer mensagem.
\end{abstract}

(Mário de Andrade, Elegia de Abril)

As elaborações críticas de Mário de Andrade e de José Carlos Mariátegui foram por nós desenvolvidas pela reflexão sobre o caráter nacional, que deveria, para estes autores, constituir a formação da literatura e da arte para a modernidade latino-americana. Com isso podemos dizer que estes intelectuais visaram construir um tipo de método para a análise da cultura de seus países no qual se ressaltam o momento histórico-social da produção da arte e o estudo sobre o desenvolvimento de seus procedimentos técnicos. Para que possamos concluir essas questões, primeiramente iremos abordar uma terceira proposição, referente à função da obra, para que possamos chegar ao fim de nossa investigação através da compreensão das perspectivas pelas quais a crítica de Andrade e a de Mariátegui procuravam se inserir no contexto social. É possível traçar uma analogia entre o que Mário de Andrade irá denominar como "os imperativos econômicos" que condicionam a inteligência e as observações de Mariátegui sobre os meios de produção, quando o autor peruano avalia esta relação como: "una servidumbre vale lo que la otra" ${ }^{27}$. Ao tomarmos neste

\footnotetext{
127 "El arte depende hoy del dinero; pero ayer dependió de una casta. El artista de hoy es un cortesano de la burguesía; pero el de ayer fue un cortesano de la aristocracia." MARIÁTEGUI,
} 
capítulo o contexto da obra de arte, como referência de nossas análises, procuramos averiguar como Mário de Andrade e José Carlos Mariátegui avaliam a criação e a produção dessas obras diante das condições que determinam a posição social do artista e do intelectual ${ }^{128}$.

Conforme abordado no capítulo anterior, tanto Mário de Andrade como José Carlos Mariátegui tentaram refletir sobre os valores sociais intrínsecos ao fazer artístico, e como a obra de arte torna-se objeto de mediação entre o artista e a expressão cultural de uma época. A Arte, uma vez que é representada pela linguagem, se valendo de recursos próprios à sua expressão, como a beleza e a técnica, auxiliam para a realização social da obra ${ }^{129}$. Podemos dizer que esta condição retoma de certo modo as questões que norteiam os valores de forma e conteúdo para análise das obras, tendo em vista que as "modalidades de comunicação influem mais na forma" e os "valores e ideologias contribuem principalmente para o conteúdo"130.

A diferença entre arte "pura" ou uma arte "interessada", assim denominadas por Mário de Andrade, relaciona-se à proximidade maior ou menor da arte em relação aos interesses individuais ou coletivos da vida política e social. De modo correlato, a atitude individual ou social do artista vincula-se também a uma perspectiva em que o primeiro tem como horizonte de sua produção apenas aquilo que julga o "melhor para si", enquanto a atitude social distende seus interesses aos intuitos coletivos. Estas dualidades percorrerão alguns dos textos de Andrade, uma vez que o autor muitas vezes se via envolto destas mesmas preocupações em relação à sua própria ação como artista e intelectual. Esta diferenciação de posições, a individual ou a coletiva, é uma questão que se distinguiu de uma época a outra da história social da arte, uma vez que ao posição do artista varia de uma época a outra: num determinado momento, o artista é considerado como

José Carlos. "El Artista y la Época". In: El Artista y la Época. 14 ed. Lima: Biblioteca Amauta, 1990, p. 17.

${ }^{128}$ MELLO E SOUZA, Antonio Candido. "A Literatura e a vida social". In: Literatura e Sociedade. 8. ed. São Paulo: T. A. Queiroz, 2000; Publifolha, 2000, p. 27.

${ }^{129}$ ANDRADE, Mario de. "Pintores e pinturas". In: O empalhador de passarinho. 4 ed. Editora Itatiaia, 2002, p. 228 - 229.

130 Ibidem, p. 27. 
um "eleito dos deuses", e em outro, encontra-se submetido a uma produção vinculada aos "donos da vida". Dessa maneira, a arte é gerada perante momentos em que ora o artista e a obra estão sob o jugo e "proteção" da aristocracia, ora sob os interesses da burguesia.

O intelectual do século XVIII vivia sob a "proteção" de príncipes ou mecenas, os quais, pode-se dizer, exigiam destes seus "trabalhadores" obras que servissem diretamente a seus interesses. Com o século XIX, os artistas e intelectuais já não servem mais a um mecenas em particular, o que aparentemente libertou sua produção artística de interesses específicos ${ }^{131}$. Esta dicotomia entre o artista sujeito à dominação aristocrática ou à burguesa estará presente tanto nos textos de Mário de Andrade como nos de José Carlos Mariátegui. Assim seria importante abordar a questão, sobre a que se referem propriamente esses "interesses". Em contraposição, o que se entende por "liberdade" junto ao novo sistema de produção é um conceito a ser também investigado. Podemos dizer que tanto em Andrade, como em Mariátegui, a relação entre arte e público é o que move especificamente os interesses daqueles que dominam as relações de poderes.

No texto Pintores e pinturas (1940), Mário de Andrade tece um debate com o crítico de arte Sérgio Milliet, a respeito da distinção entre forma e conteúdo na arte. De acordo com suas palavras essa distinção é compreendida através da relação entre a técnica e o assunto, variando, no entanto, de acordo com o contexto histórico, junto ao qual deve ser avaliado o porquê destas perspectivas se modificarem ao longo do tempo. Segundo esse escritor, a técnica, que é um problema, na arte da pintura, de "cores", de "desenho", de "volumes", e de "equilíbrios", "não tem o poder pra afastar o povo da arte, nem siquer o individualismo verdadeiramente artístico". No que se refere as transformações que ocorrem sobre a temática, quando o assunto passa de temas mais abstratos e que contemplam "valores morais humanos" - como a religião, a honestidade, o castigo, dentre outros -, para assuntos mais concretos, como os quadros de paisagem e a sistematização da natureza-morta, percebe-se o afastamento entre a arte e o

\footnotetext{
${ }^{131}$ ANDRADE, Mário de. Entrevistas e depoimentos. Org. Telê Porto Ancona Lopez. Ed. II. São
} Paulo; T. A. Queiroz, 1983, p. 103-104. 
público $^{132}$. De uma época a outra, da ascensão da aristocracia e posteriormente da burguesia, altera-se a relação entre aqueles que dominam e aqueles que são dominados, devido à aparente "liberdade" de transição entre uma classe social à outra. Por isso para a aristocracia, cujos vínculos pessoais sustentavam muitas vezes as relações de poder, a arte nada mais é que um meio de comunicação, entre ela e o povo, que mantém para sustentar a sua posição. Já a burguesia, procura se afastar do povo, para que com este distanciamento afastar-se de sua própria origem. Com isso, os temas tornam-se mais livres, e assim também destituídos dos valor simbólico e das referências tradicionais. Dessa maneira, podemos dizer que, a relação entre arte e público, para Mário de Andrade, mantém-se através do uso de uma linguagem que procura, através dos assuntos nela abordados, questionar a possibilidade da expressão artística frente aos intuitos ideológicos que procuram por meio da arte, impor a sua hegemonia.

Mário de Andrade, contudo, avalia a idéia de liberdade formal na arte, a partir das vanguardas artísticas, quando alguns artistas passaram a confundir conhecimento técnico com a idéia de arte pura e arte interessada.

Acho que o artista, mesmo que queira, jamais deverá fazer uma arte desinteressada. $O$ artista pode pensar que não serve a ninguém, que só serve à Arte, digamos assim. Aí está o erro, a ilusão. No fundo, o artista está sendo um instrumento nas mãos de poderosos. O pior é que o artista honesto, na sua ilusão de arte livre, não se dá conta de que está servindo de instrumento, muitas vezes para coisas terríveis. (ANDRADE, [1944], 1983, p. 103)

Dessa maneira, não só o artista, mas também o crítico torna-se abstencionista de sua função, a partir das necessidades que se interpõe entre as idéias e realidade social:

(...) mudam de idéias a qualquer notícia, não resistem ao sopro de qualquer brisa. Mas que podem fazer, se carecem de pão, se precisam pagar o médico da família? Pão e doença, filho gripado e mulher grávida, são hoje para a inteligência os mais fáceis avatares do cinismo moral. (ANDRADE, [1941], 2002, P. 208.

\footnotetext{
${ }^{132}$ ANDRADE, Mário de. "Pintores e pintura". Idem, p. 228 - 229.
} 
Esta questão, das relações sociais que "sustetam" os objetos culturais, se apresenta de forma bastante contundente nos artigos de Mário de Andrade lançados no jornal Folha da Manhã, em uma série de crônicas publicadas sob o título O Banquete (1944-1945). Neste texto Andrade elabora um encontro entre representantes das classes dominantes e dominadas, representados por personagens que parecem refletir condições bastante próximas à realidade social: a mecenas, Sarah Light, que era uma milionária estrangeira e de formação burguesa; Félix de Cima, de origem italiana e representante do governo; Siomara Ponga, uma artista célebre, culta, mas de intuitos e atitudes individualistas perante a arte, e por fim Janjão, um artista virtuose, que no entanto, representava uma classe mais popular e era interessado na arte social.

Estas relações, embora fictícias, parecem ilustrar o modo como Mário de Andrade chega, ao final de sua vida, a compreender as relações que estão em torno da produção artística. Como se dão os processos de criação artística? Qual o verdadeiro "destino" da arte?

No texto sobre O Cabotinismo (1939), Andrade qualifica a atitude do artista através da idéia de "sinceridade" pela qual este imbui sua obra. Esta "sinceridade" é regida pelos objetivos que conduzem o artista em suas criações, por meio de seus "móveis secretos", que são relacionados às razões internas do artista ${ }^{133}$, como suas ambições "desprezíveis" e "imorais" que se revelam na origem de seus gestos não apenas sociais, mas também artísticos. A criação também é conduzida, por outro lado, pelos "móveis aparentes", que são as idéias passíveis de serem apresentadas socialmente, mas que, no entanto, não se apresentam mais como "idéias-origens", ou seja, não se apresentam tal qual pensadas inicialmente, mas já refletidas e transformadas em arte, como "idéiasfinalidades"134. Para além dos motivos de qualquer "amor à vida e à humanidade", que se pensa ser uma das causas maiores que conduzem a criação artística,

\footnotetext{
133 "É que o maior tempo da nossa existência nós o empregamos em nos escondermos do que somos terrestremente. A nossa inteligência, em principal pela chamada "voz da consciência" ou que nome the derem, reconhece que o nosso indivíduo é por muitas partes coisa abjeta que a horroriza". ANDRADE, Mário. "Do Cabotinismo". In: O Empalhador de Passarinho. 4. ed. Editora Itatiaia, 2002, p. 84.

${ }^{134}$ Ibidem, p. 84.
} 
Mário de Andrade aponta motivos menos "nobres" que determinam muitas vezes o processo do fazer artístico:

O artista perfeito nunca perderá de vista o seu público, e isto é cabotinismo. $O$ artista completo jamais perderá de vista a ambição de se tornar ou se conservar célebre, e tudo isto é cabotinismo. E como é o público que faz a grandeza de um artista (falo "público" mesmo no sentido de elite pequena, que alguns artistas possivelmente preferem), estas duas ambições de público a julgar e celebridade a conquistar - alheias ao conceito específico de arte - regem de forma importante o comportamento criador do artista. (ANDRADE, [1939], 2002, p. 83)

Esta constatação, a dos diversos cabotinismos aos quais estão sujeitas as obras de arte, não diminuem o seu valor. Contudo Mário de Andrade irá diferenciar este processo criador quando se volta à análise da arte perante a situação do contexto artístico nacional e da crítica brasileira. Se por um lado a criação artística está imbuída de "sentimentos" vários que regem os processos "secretos" ou "aparentes" do artista para a construção da obra, por outro, esta mesma obra possui procedimentos técnicos e expressivos que devem ser avaliados criticamente.

Cabe à crítica, mesmo que se torne incivil e antipática, chamar ao tostão pelo seu modesto nome de tostão. Crítica e condescendência são coisas divorciadas desde sempre, mormente nos países de pequena cultura, onde freqüentemente os artistas se improvisam à custa de talento muito e nenhum saber. Substitui-se a técnica pelo brilho disfarçador, o cuidado da forma por uma vaga (e aliás facilmente intimidada) intenção social. (ANDRADE, [1939], 2002, p. 105)

Para o escritor, o conhecimento é indispensável a qualquer artista, pois uma vez que a beleza em arte "é um problema de técnica e forma", é imprescindível que o artista as domine, para que possa assim se expressar. A relação entre forma e conteúdo até aqui é vista de maneira intrínseca uma à outra, já que a técnica, ou seja, o conhecimento do artista deve ser transmitido por uma 
forma que the sintetize ${ }^{135}$. No entanto, Andrade, ao analisar o contexto brasileiro, aponta como a precariedade, nos artistas novos, em geral, se dá muitas vezes à custa de confusões entre liberdade formal e ausência de conhecimento técnico.

Os que desejarem saber o que significavam dissolução e libertinagem nos que estavam um bocado conscientes em 1922, vão procurá-las em Manuel Bandeira, este um escritor culto, um esteta, que sabe o dinamismo de um ritmo, o segredo de adequação de uma forma ao seu conteúdo, o valor da expressão lingüística exata, e o perigo de uma palavra em falso, capaz de sacrificar uma mensagem. (ANDRADE, [1939], 2002, p. 107)

O mesmo rigor quanto ao procedimento técnico e formal é visto, por Andrade, quanto ao procedimento crítico do intelectual, dado que este, no geral, não possui qualquer método de análise de obras. Assim, entende que a crítica deve ser

(...) nem exclusivamente estética, nem ostensivamente pragmática, mas exatamente aquela verdade transitória, aquela pesquisa das identidades "mais" perfeitas que, ULTRAPASSANDO AS OBRAS, BUSQUE REVELAR A CULTURA DE UMA FASE E LHE DESENHE A IMAGEM. (ANDRADE, [1939], 2002, p. 106)

Ao analisarmos alguns textos de José Carlos Mariátegui sobre a posição do artista em relação à sociedade, temos também uma série de fatores voltados ao meio de produção interferindo diretamente no processo da obra. No artigo El Artista y la Epoca, publicado em 1925, verificamos que a condição do artista quanto ao reconhecimento ou não de sua obra está diretamente ligada às condições do mercado da arte.

Para o crítico peruano, o artista moderno vive um contraste próprio à sua época, referente à liberdade de criação versus o sacrifício de sua personalidade

135 "E, com efeito, todo e qualquer sentimento outro, toda e qualquer verdade, toda e qualquer intenção, não consegue se tornar beleza, si não se transformar nesse sentimento técnico, que contempla o amor, a verdade, a intenção social e lhes dá forma. Forma estética, isto é, a obra-dearte. Não mais a realidade, mas como que o seu símbolo - esse formidável poder de convicção da beleza que a torna mais real que a própria realidade". ANDRADE, Mário. "A Rapoza e o Tostão". Idem, p. 109) 
artística $^{136}$. Na sociedade burguesa, o valor atribuído a uma obra de arte não se relaciona mais ao conhecimento formal e técnico intrínseco a ela, mas às condições de negociação dessa obra.

Los artistas más puros no son casi nunca los mejores cotizados. El êxito de un pintor depende, más o menos, de las mismas condiciones que el éxito de un negocio. Su pintura necesita uno o varios empresarios que la administren diestra y sagazmente. (MARIÁTEGUI, [1925], 1990, p. 13)

Perante estes condicionamentos sociais que vinculam o fazer artístico à sobrevivência do artista, a obra é colocada em segundo plano de importância. Para Mariátegui, o artista contemporâneo acaba por preocupar-se mais em divulgar sua imagem, em tornar-se célebre, e atingir com isso uma boa divulgação de sua obra e pessoa nos espaços dos jornais ${ }^{137}$, que propriamente com valores relativos à sua obra. A partir desse reconhecimento público, construído por meio da crítica jornalística e da publicidade dela decorrente, o artista estaria "apto" a ter sua obra finalmente inserida no mercado de arte.

La publicidad, el réclame, en general, son en nuestro tiempo omnipotentes. La fortuna de un artista depende, por consiguiente, muchas veces, sólo de un buen empresario. Los comerciantes en libros y los comerciantes en cuadros y estatuas deciden el destino de la mayoría de los artistas. (MARIÁTEGUI, [1925], 1990, p. 16-17)

Segundo Mariátegui, a pretensa "liberdade" expressiva, advinda com a democracia, e implementada pela sociedade burguesa, é controversa, pois essa "liberdade" cria novos tipos de exploração. O artista passa a repudiar o tempo presente em nome de sua "nostalgia do passado". Este olhar procura retomar e comparar a condição de sua posição social perante as vinculações de produção de sua arte sob a tutela dos mecenas da Idade Média ou do Renascimento,

136 "El artista debe sacrificar su personalidad, su temperamento, su estilo, si no quiere, heroicamente, morirse de hambre". MARIÁTEGUI, José Carlos. "El Artista y la Época". In: El Artista y la Época. 14 ed. Lima: Biblioteca Amauta, 1990, p. 13.

137 "Sobre la suerte de los artistas contemporáneos pesa, excesivamente, la dictadura de la prensa. Los periódicos pueden exaltar al primer puesto a un artista mediocre y pueden relegar al último a un artista altísimo. La crítica periodística sabe su influencia. Y la usa arbitrariamente." Ibidem. P. 16. 
representados, ilusoriamente, por uma classe mais culta e inteligente, diferente da mediocridade do "novo rico".

Seria mesmo diferente a condição de produção e reconhecimento artístico entre o artista que dependia de uma sociedade feudal e outro da sociedade capitalista? Mariátegui analisa esta relação por meio da formação cultural da aristocracia e da burguesia. Se para a primeira, a criação artística constituía um dos maiores fins humanos, pois era ao mesmo tempo teoria e prática, uma vez que a classe dominante - a igreja e a monarquia - incluía em seus hábitos gosto pelas artes e letras. Já em relação à burguesia, a atividade prática exclui da vida das pessoas toda a atividade estética.

El arte depende hoy del dinero, pero ayer dependió de una casta. El artista de hoy es un cortesano de la burguesia; pero el de ayer fue un cortesano de la aristocracia. (MARIÁTEGUI, [1925], 1959, p. 17)

A partir dessa divisão entre a função do artista, perante a época da Idade Média e o Renascimento, bem como as mudanças de perspectiva desse artista perante o contexto no qual sua obra é inserida, a da "liberdade" do mercado de arte - e com isso o da transformação da arte em mercadoria - tem-se a retirada do artista perante esta nova forma de relação entre sua produção artística diante dos conflitos econômicos e sociais que enfrenta. Estes artistas isolaram-se em suas "torres de marfim", e com isso distanciaram-se das questões que envolvem a arte e a vida.

El oreden espiritual, el motivo histórico de la Torre de Marfil aparecen muy lejanos de nosotros y resultan muy extraños a nuestro tiempo. El "torremarfilismo" formó parte de esa reacción romántica de muchos artistas del siglo pasado contra la democracia capitalista y burguesa. (MARIATEGUI, [1924], 1959, p. 26)

Por conseguinte, para Mariátegui, a burguesia perde seu valor moral, e perante a inquietude da época moderna, as relações com o passado tornam-se motivos ou temas esvaziados de qualquer tradição, o que leva a muitos artistas buscarem em torno das "filosofias do retorno" a tentativa de construção na modernidade de um novo "espírito". 
Ao tomarmos parte das discussões de Mário de Andrade e José Carlos Mariátegui sobre as relações de poder que engendram o processo da produção artística, verificamos que estes dois intelectuais encontram-se quanto a crítica que tecem sobre a condição do artista e da arte diante das transformações políticas, econômicas e culturais que desenvolvem-se com as diferentes épocas históricas. Diante desta constatação, podemos dizer que esta postura crítica distende-se nestes dois autores perante os conceitos que se valem para a análise da tradição e da modernidade latino-americana. Tanto Mário de Andrade, como José Carlos Mariátegui compreenderam a história a partir de fatos que analisaram desde o período clássico ao mais contemporâneo, o que acaba por refletir-se em seus textos no modo como ambos autores referenciam a importância do conhecimento técnico e histórico para a análise da realidade cultural de seus países.

A pesquisa sobre a identidade cultural, pautada nas singularidades da mistura étnica, denota o interesse destes intelectuais perante o compromisso de compreenderem a realidade, por meio de relações que envolvem as particularidades locais, tanto do Brasil, como no Peru. A consciência deste "subdesenvolvimento", engendrado pela colonização portuguesa e espanhola, leva Mário de Andrade e José Carlos Mariátegui a empenharem-se profundamente, através de suas obras, na idéia de construção e interpretação da realidade cultural. O olhar para a tradição, como fonte primeira de referência para a constituição de um imaginário local, bem como as investigações sobre o popular e o folclórico, denotam o interesse de ressignicação dos valores nacionais presente nesses escritores. No entanto, o mote impulsionador para a revisão e importância da realidade local, se dá perante o contato com a influência estrangeira, quando do processo de modernização das cidades e da formação de centros cosmopolitas, o que gera um intenso intercâmbio de idéias.

Podemos dizer que tanto Mário de Andrade como José Carlos Mariátegui tornaram-se através de suas obras e de suas atividades como intelectuais, mediadores das reinterpretações simbólicas que visavam resgatar através da 
tradição local, a identidade do povo brasileiro e peruano.. De acordo com Renato Ortiz:

Se os intelectuais podem ser definidos como mediadores simbólicos é porque eles confeccionam uma ligação entre o particular e o universal, o singular e o global. Suas ações são, portanto, distintas daquelas que encarnam a memória coleiva. (ORTIZ, 2006, p. 139)

Através do entendimento que desenvolveram sobre as manifestações primitivas, encontraram no realismo e na deformidade expressiva a possibilidade de configurar uma identidade brasileira e peruana que, muitas vezes, levaram-nos ao sacrifício de suas próprias obras. 


\section{III - B i b i ogr a fi a}

Dos autores estudados

\section{Mário de Andrade:}

ANDRADE, Mário de. "A escrava que não é Isaura" (1922-1925). In: Obra Imatura. São Paulo: Martins, 1960.

. A lição do amigo: cartas de Mário de Andrade a Carlos Drummond de Andrade. 2. ed. revista. Rio de Janeiro: Record, 1988.

. Amar, verbo intransitivo. Belo Horizonte: Itatiaia, 1982.

. Aspectos das Artes Plásticas no Brasil. Belo Horizonte: Itatiaia, 1984.

. Aspectos da Literatura Brasileira. Belo Horizonte: Itatiaia, 2002.

. Cartas de Mário de Andrade a Prudente de Moraes, neto, 1924/1936.

[Organizado por] Georgina Koifman. Rio de Janeiro: Nova Fronteira, 1985.

. Entrevistas e Depoimentos/Mário de Andrade. Ed. org. Têle Porto Ancona

Lopez. São Paulo: T. A. Queiroz, 1983. (Biblioteca de letras e ciências humanas; série 1 : Est.brasileiros; v. 5)

- Querida Henriqueta: cartas de Mário de Andrade a Henriqueta Lisboa.(Revisão, introdução e notas de Lauro Palú). Rio de Janeiro: José Olympio, 1991.

- Macunaíma. Ed. crítica de Têle Porto Ancona Lopez. Paris/Brasília: Archives/CNPq, 1988.

. Macunaíma: o herói sem nenhum caráter. Ed. Crítica de Telê Porto Ancona Lopez. Rio de Janeiro-São Paulo: Livros técnicos e científicos-Secretaria da cultura, ciência e tecnologia, 1978.

. "O Movimento Modernista". In: Aspectos da Literatura Brasileira. São Paulo: Martins Fonte, 1974, p. 232-255.

.o Empalhador de Passarinho. Belo Horizonte: Itatiaia, 2002.

.o Baile das Quatro Artes. Rio de Janeiro: Livraria Martins Editora, [s.d.].

.Paulicéia Desvairada. São Paulo: Casa Mayença, 1922. [ed. Fac-símile] 
.Poesias completas. Ed. crítica de Diléa Zanotto Manfio. São Paulo: Itatiaia/Edusp, 1987.

. Será o Benedito!. São Paulo, Editora da PUC-SP, 1992.

\section{Artigos:}

ANDRADE, Mário de. "Arte Alemã I e II". Diário Nacional. Biblioteca Mário de Andrade. 6 e 9 de out. 1928.

. "Expressionismo". Diário Nacional. Biblioteca Mário de Andrade. 10 jan. 1928.

. "Questão de arte". Diário Nacional, 30 set. 1927.

. "Candido Portinari", Revista Acadêmica, Rio de Janeiro, n. 48, fev. 1940.

. "Portinari", Revista Acadêmica, Rio de Janeiro, n. 35, maio 1938.

. "Portinari", Bellas Artes, São Paulo, out. 1938.

. "Portinari", Diário de São Paulo, São Paulo, 15 dez. 1934.

. "Obras de Candido Portinari". O Estado de São Paulo, São Paulo, abr. 1939.

\section{Jos é Carlos Mariát egui:}

MARIÁTEGUI, José Carlos. El artista y su Época. 14 ed. Lima: Biblioteca Amauta, 1990.

. Ideología y Política. Lima: Biblioteca Amauta, 1969.

. La Escena Contemporánea. Lima: Minerva, 1925.

. Mariátegui. Org. Manuel L. Bellotto e Anna Maria M. Corrêa. São Paulo: Ática, 1982.

. Peruanicemos al Perú. Lima: Biblioteca Amauta, 1970.

. Por um socialismo indo-americano: ensaios escolhidos. Sel. intr. Michael

Löwy. Trad. Luiz Sérgio Henriques. Pensamento Crítico, v. 4. Rio de Janeiro: UFRJ, 2005.

MARIÁTEGUI, J.C. e SÁNCHEZ, Luis Alberto. La poetica del Indigenismo. Lima: Mosca Azul, 1976. 
MARIÁTEGUI, José Carlos. 7 Ensayos de Interpretacion de la realidad peruana. Prólogo Aníbal Quijano. Caracas: Biblioteca Ayacucho, v. 69, [s.d.].

. 7 Ensaios de Interpretação da realidade peruana. Trad. Salvador Obiol de

Freitas e Caetano Lagrasta. Pref. Florestan Fernandes. São Paulo: Alfa-Omega, 1968.

. 7 Ensayos de Interpretacion de la realidad peruana, Lima : Amauta, 1958. . Temas de Educacion. Lima: Biblioteca Amauta, 1986.

\section{Bibliografiageral}

ABBAGNANO, Nicola. Dicionário de Filosofia. Trad. e rev. Alfredo Bosi. São Paulo:

Ed. Mestre Gou, 1970.

ADES, Dawn. Arte na América Latina: a era moderna, 1820-1980. Dawn Ades; com

a contribuição de Guy Brett, Stanton Loomis Catlin e Rosemary O'Neill; [trad.

Maria Thereza de Rezende Costa]. São Paulo: Cosac \& Naif Edições, 1997.

ALMEIDA, Paulo Mendes de. De Anita ao Museu. São Paulo: Ed. Perspectiva, 1976. (Coleção Debates, 133)

AMARAL, Aracy A. Artes Plásticas na Semana de 22. 5 ed. São Paulo: Ed. 34. 1998.

ANTELO, Raúl. Na ilha de Marapatá: Mario de Andrade lê os hispanoamericanos. São Paulo-Brasília: HUCITEC-INL, Fundação Nacional PróMemória, 1986.

ARGAN, Giulio Carlo. Arte Moderna. Trad. D. Bottmann e F. Carotti. São Paulo: Companhia das Letras, 1992.

AVANCINI, José Augusto. Expressão Plástica e consciência nacional na crítica de Mário de Andrade. 1992, 228 p. Tese (Doutorado em Filosofia, Crítica (Artes) e Artes Plásticas). Orientação Profa Otília Arantes. Faculdade de Filosofia, Letras e Ciências Humanas, Universidade de São Paulo.

BANDEIRA, Manuel. Literatura hispano-americana. Rio de Janeiro: Pongetti, 1949. . "Mario de Andrade e a questão da língua". In: De poetas e de poesias. Edições de Ouro. Rio de Janeiro: Tecnoprint, 1967, p. 11-28. 
BATISTA, Marta Rossetti. Anita no tempo e no espaço: biografia e estudo da obra. São Paulo: Ed. 34; Edusp, 2006.

BAZAN, Armando. Mariátegui y su tiempo. Lima: Biblioteca Amauta, 1987.

BOSI, Alfredo. "Mariátegui: a vanguarda enraizada". In: Revista Nossa América: julh.-ag. 1990, p. 03-10.

CAMPOS, Haroldo de. Morfologia do Macunaíma. São Paulo: Perspectiva, 1973.

CANCLINI, Nestor G. Culturas Híbridas: Estratégias para entrar e sair da modernidade. Trad. E Intr. Gênese Andrade. 4. ed. São Paulo: Editora da Universidade de São Paulo, 2006. (Ensaios Latino-americanos, 1)

CANDIDO, Antonio. Literatura e Sociedade. São Paulo: T.A. Queiroz: Publifolha, 2000. (Grandes nomes do pensamento brasileiro)

CASTRO, Augusto. "Mariátegui: Estética y modernidad" En: G. Portocarrero, F. Cáceres y R. Tapia (Eds) La Aventura de Mariátegui: Nuevas Perspectivas, Pontificia Universidad Católica del Perú, 1995. pp 179-208.

CHAUÍ, Marilena. Cidadania Cultural. 1. ed. São Paulo: Editora Fundação Perseu Abramo, 2006.

O que é ideologia. São Paulo: Brasiliense, 2006.

CHIARELLI, Domingos Tadeu. De Almeida Jr. Almeida Jr.: A crítica de arte de Mário de Andrade. 1996, 2 v., 358 p. Tese (Doutorado em Artes Plásticas). Escola de Comunicação e Artes, Universidade de São Paulo.

FABRIS, Annateresa. "Mário de Andrade e o Aleijadinho: o Barroco visto pelo Expressionismo". In: Barroco 12: anos 1982/3. Instituto Estadual do Patrimônio Histórico e Artístico de Minas Gerais (IEPHA/MG), p. 227-230.

. O futurismo paulista: hipótese para o estudo da chegada da vanguarda no Brasil. São Paulo: Perspectiva:Ed. da Universidade de São Paulo, 1994. (Estudos; v. 138)

. (org.). Modernidade e modernismo no Brasil. Campinas, São Paulo: Mercado de Letras, 1994.

. Cândido Portinari. São Paulo: Edusp, 1996.

. Portinari, pintor social. São Paulo: Editora Perspectiva: Secretaria de Estado da Cultura, 1990. 
GRAMSCI, Antonio. Intelectuais e a organização da cultura. Rio de Janeiro: Civilização Brasileira, 1978 (publicado em 1979).

. Literatura e vida nacional. Rio de Janeiro: Civilização Brasileira, 1978.

JACKSON, Luiz Carlos. A tradição esquecida: os parceiros do Rio Bonito e a sociologia de Antônio Candido. Belo Horizonte: Ed. UFMG; São Paulo: FAPESP, 2002.

JOZEF, Bella. História da literatura hispano-americana. 3. ed. Rio de Janeiro: F. Alves; 1989.

A máscara e o enigma. A modernidade: da representação à transgressão. Rio de Janeiro: F. Alves, 2006.

KOSSOVITCH, Leon. "As artes plásticas: Mário de Andrade e seu método". In:

Discurso. Ano I, $\mathrm{n}^{\circ}$ I, Faculdade de Filosofia, Letras e Ciências Humanas da Universidade de São Paulo, 1971, p. 83-96.

LITERATURA E SOCIEDADE. Revista do Departamento de Teoria Literária e Literatura Comparada. Faculdade de Filosofia, Letras e Ciências Humanas da Universidade de São Paulo, n. 1 (1966). São Paulo: USP/FFLCH/DTLLC, 1996.

LAFETÁ, João Luiz. 1930: A crítica e o modernismo. São Paulo: Ed. Duas Cidades/Ed. 34, 2001.

LARRAYA, Antonio Pages. "Mariátegui y el realismo magico". In: Cuadernos Hispanoamericanos. n 325, Madrid (julio 1977), pp. 149-154.

LAUER, Mirko. Antologia de la poesia vanguradista peruana. Lima: Ediciones El Virrey, 2001. Introduccion a la Pintura Del Siglo XX. Lima: Mosca Azul Editores, 1976.

LENCl, Yasmín López. El Laboratório de la vanguardia literaria en el Peru: trayectoria de una gênesis a tráves de las Revistas Culturales de los años veinte.Lima: Editorial Horizonte, 1999.

LOPEZ, Telê P. Ancona. "Arlequim e Modernidade". In: Revista do Instituto de Estudos Brasileiros da Universidade de São Paulo. N. 21. São Paulo: USP, 1979, p.85-100. 
. Mário de Andrade: Ramais e Caminho. São Paulo: Livraria Duas Cidades, 1972.

. Macunaíma: a margem e o texto. São Paulo, Hucitec, 1974.

. "Uma difícil conjugação". In: ANDRADE, Mário de. Amar, verbo intransitivo. 10 ed. Belo Horizonte: Itatiaia, 1982, p. 9-44.

LOSADA GUIDO, Alejandro. Creación e Práxis: La produccion literaria como praxis social en hispanoamerica y el Peru. Lima: Universidad Nacional Mayor de San Marcos, 1976.

LÖWY, Michael; SAYRE, Robert. Romantismo e Política. Trad. Eloísa de Araújo Oliveira. Rio de Janeiro: Paz e Terra, 1993.

MARX-ENGELS. Sobre Literatura e Arte. Trad. Olinto Beckerman. São Paulo: Global Editora, 1980.

MELLIS, Antonio. "José Carlos Mariátegui hacia el siglo XXI". Cuadernos de Recienvenido. São Paulo: Publicação do Curso de Pós Graduação em Literaturas Espanhola e Hispano-Americana - FFLCH/USP, n.1, 1996.

. Leyendo Mariátegui. Lima: Biblioteca Amauta, 1999.

MORAES. Marcos Antonio de. Correspondência Mário de Andrade e Manuel Bandeira. São Paulo: Edusp/IEB, 2000.

MORAIS, Frederico. Panorama das Artes Plásticas, Séculos XIX e XX. $2^{\mathrm{a}}$ ed. rev. São Paulo: Instituto Itaú Cultural, 1991.

NETTO, José Paulo. "O contexto histórico-social de Mariátegui". Encontros com a Civilização Brasileira. Rio de Janeiro, Civilização Brasileira, nº 21, 1980. NÚÑEZ, Estuardo, "En Alemania". In: La Experiencia Europea de José Carlos Mariátegui. Lima: Amauta, 1978, p. 49-67.

. "José Carlos Mariátegui y el Expresionismo Alemán". In: ABRIL, Xavier et al.

Mariátegui y la Literatura. Lima: Amauta, 1980, p. 137-148.

. "Expressionismo en la pesía indigenista del Perú". In: The Spanish Review 2. New York, nov. 1935, p. 69-80.

. "José Carlos Mariátegui y la recepcion del surrealismo en el Peru". In: Revista de Crítica Literária Latinoamericana 3, nº 5 (1977), pp. 57-66. 
ORTEGA Y GASSET, José. A desumanização da arte. Trad. Ricardo Araújo, 5. ed. São Paulo: Cortez, 2005.

. El tema de nuestro tiempo. El ocaso de las revoluciones, El sentido histórico de la teoría de Einstein. Madrid : Calpe, 1923.

PARR, Martin, BADGER, Gerry. The Photobook: A History. vol. II, Londres: Phaidon, 2006, p. 26.

PAZ, Octavio. Los Hijos del Limo: del Romanticismo a laVanguardia. Barcelona: Ed. Seix Barral, 1974. (Série Biblioteca Breve)

PINTURA CONTEMPORÂNEA: 1920-1960. José Antonio de Lavalle e Werner Lang (org.). Lima: Banco de Crédito del Perú en la Cultura, 1998. (Colección Arte y Tesoros del Perú)

PIRES JUNIOR, Sidney Oliveira. Embates de um Intelectual Modernista: Papel do Intelectual na correspondência de Mário de Andrade. 2004, 223 p. Tese (Doutorado em História Social). Faculdade de Filosofia, Letras e Ciências Humanas, Universidade de São Paulo.

PROENÇA, M. Cavalcanti. Roteiro de Macunaíma. 4. ed. Rio de Janeiro-Brasília:

Civilização brasileira-INL, 1977.

REVISTA AMAUTA: revista mensual de Doctrina, Literatura, Arte, Polemica. Edicion en Facsímile; Lima; Empresa Editora Amauta S.A., 1926, nº 01-30.

REBOLLO GONÇALVES, Lisbeth. "Mário de Andrade e Mariátegui: crítica de arte e consciência nacional". Arte e Cultura na América Latina. São Paulo: Sociedade Científica de Estudos da Arte - CESA, v. VII, n. 2, p. 38-47, $2^{\circ}$ sem. 2000.

RODRIGUES MONEGAL, Emir. Mário de Andrade e Borges. São Paulo: Perspectiva, 1978.

RODRÍGUEZ, Maria Candelária Hernández. El Indigenismo en diálogo. CanariasAmérica 1920 - 1950. Canarias: Centro Atlántico de Arte Moderno/ Instituto de Canárias "Cabrera Pinto", 2001.

ROSENFELD, Anatol. Texto/Contexto. São Paulo: Ed. Perspectiva, Instituto Nacional do Livro/MEC, 1973. (Coleção Debates: 7)

SABOGAL, José. El desvan de la imagineria peruana. Banco Central de Reserva del Peru: Fondo Editorial, 1988. 
SANCHEZ, Luis Alberto. "Amauta: su proyeccion y su circunstancia". In: Cuadernos Americanos 1 (jan.-fev. 1977), p. 142-149.

SÁNCHEZ VÁZQUEZ, Adolfo. As idéias estéticas de Marx. Rio de Janeiro: Paz e Terra, 1968

SANTOS, Flavia Ferreira dos. A Revista de Occidente e suas estratégias de legitimação:um estudo do ano de 1929. Rio de Janeiro, 2005. Dissertação (Mestrado em Letras Neolatinas)- Faculdade de Letras, Universidade Federal do Rio de Janeiro, Rio de Janeiro, 2005. 153fl. Mimeo. Dissertação de Mestrado em Letras Neolatinas, Literaturas Hispânicas.

SCHELLING, Vivian. A presença do povo na cultura brasileira: ensaio sobre o pensamento de Mário de Andrade e Paulo Freire. Trad. Federico Carotti. Campinas, São Paulo: Editora UNICAMP, 1990.

SCHWARTZ, Jorge. Vanguardas Latino-americanas: polêmicas, manifestos e textos críticos. São Paulo: Edusp/lluminuras/Fapesp, 1995.

. Vanguarda e Cosmopolitismo na década de 20: Oliverio Girondo e Oswald de Andrade. São Paulo: Ed. Perspectiva, 1983.

SIMONE, Eliana de Sá Porto. Käthe Kollwitz. São Paulo: Ed. da Universidade de São Paulo, 2004.

SOUSA, Gilda de Mello e. O tupi e o alaúde: uma interpretação de Macunaíma. São Paulo: Duas Cidades, 1979.

TAMAYO VARGAS, Augusto. Literatura Peruana. Lima: Peisa/Editorial Inca; 1992. . Literatura Peruana y Literatura Brasileña a traves de los siglos. Lima:

Publicaciones Del Instituto de Literatura de la Universidad Mayor de San Marcos, 1957.

TAURO, Alberto. Amauta y su influencia. Lima: Biblioteca Amauta, 1989.

WILDE, Oscar. A alma do homem sob o socialismo. Trad. Heitor Ferreira. Coleção L\&PM Pocket. Porto Alegre: L\&PM, 2003. 